\author{
UNIVERSIDADE DE SÃO PAULO \\ ESCOLA DE ENGENHARIA DE SÃO CARLOS
}

SYLVIA PAES FARIAS DE OMENA

REMOÇÃO DE FENOL EM REATOR ANAERÓBIO DE LEITO FLUIDIFICADO SOB CONDIÇÕES DESNITRIFICANTES 
SYLVIA PAES FARIAS DE OMENA

\title{
REMOÇÃO DE FENOL EM REATOR ANAERÓBIO DE LEITO FLUIDIFICADO SOB CONDIÇÕES DESNITRIFICANTES
}

\author{
Dissertação apresentada à Escola de Engenharia de São \\ Carlos da Universidade de São Paulo como parte dos \\ requisitos para obtenção do título de Mestre em \\ Engenharia. \\ Área de Concentração: Engenharia Hidráulica e \\ Saneamento \\ Orientador: Prof. Dr. Edson Luiz Silva
}


FOLHA DE JULGAMENTO

Candidata: Engenheira SYLVIA PAES FARIAS DE OMENA

Dissertação defendida e julgada em 29/04/2008 perante a Comissão Julgadora:

$$
\text { Galson S Silva Aprovada. }
$$

Prof. Dr. EDSON LUIZ SILVA (Orientador)

(Universidade Federal de)São Carlos/UFSCar)

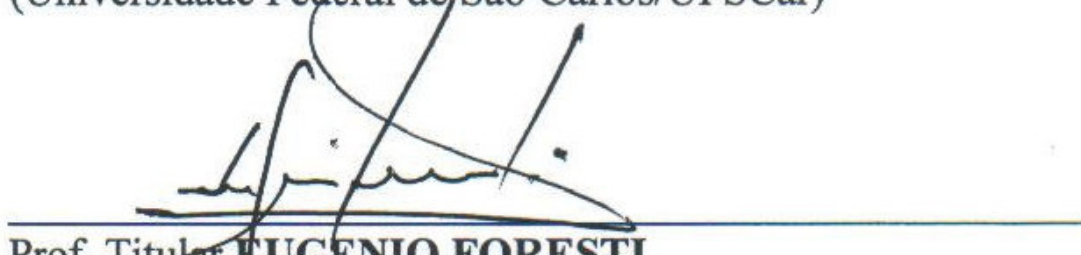

Prof. Tituar TUGENIO FORESTI

(Escola de Eugenharia de São Carlos/USP)

Ratamia Smove Qumbrace do hat APROVAAA Prof ${ }^{\mathrm{a}}$, Dr ${ }^{\mathrm{a}}$. CATARINA SIMONE ANDRADE DO CANTO (Escola de Engenharia Mauá/EEM)
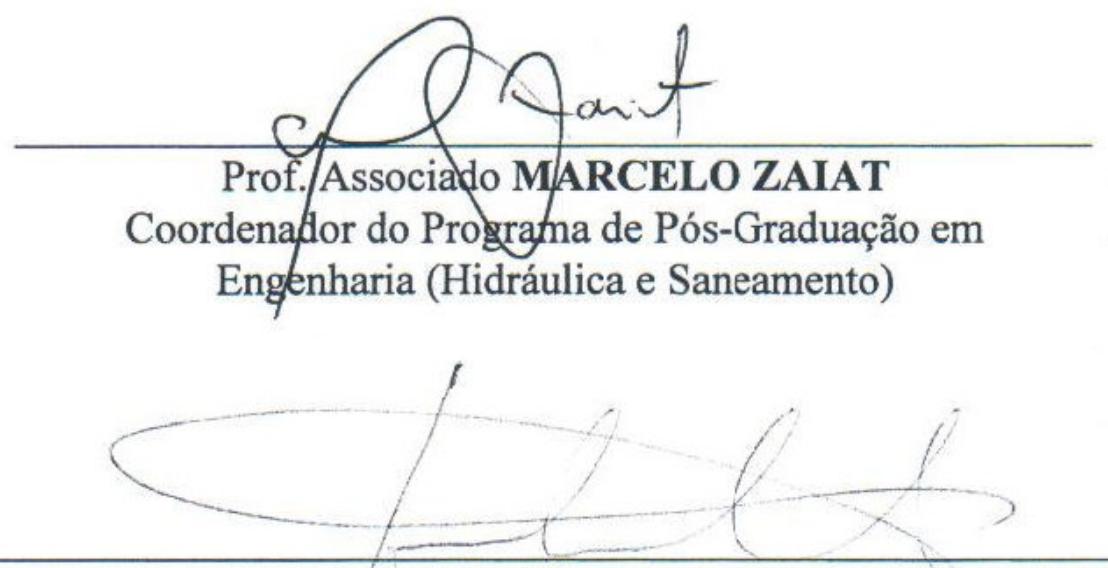

Prof. Associado GERALDO ROBERTO MARTINS DA COSTA Presidente da Comissão da Pós-Graduação da EESC 
AUTORIZO A REPRODUÇÃO E DIVULGAÇÃO TOTAL OU PARCIAL DESTE TRABALHO, POR QUALQUER MEIO CONVENCIONAL OU ELETRÔNICO, PARA FINS DE ESTUDO E PESQUISA, DESDE QUE CITADA A FONTE.

Ficha catalográfica preparada pela Seção de Tratamento da Informação do Serviço de Biblioteca - EESC/USP

Omena, Sylvia Paes Farias de
Remoção de fenol em reator anaeróbio de leito fluidicado sob condições desnitrificantes / Sylvia Paes Farias de Omena ; orientador Edson Luiz Silva. -- São Carlos, 2008 .

Dissertação (Mestrado-Programa de Pós-Graduação e Área de Concentração em Hidráulica e Saneamento) -- Escola de Engenharia de São Carlos da Universidade de São Paulo, 2008 .

1. Tratamento biológico anaeróbio. 2. Processo anóxico. 3. Fenol. 4. Nitrogênio. 5. Desnitrificação. 6. Reator anaeróbio de leito fluidificado. I. Título. 
Aos meus pais Maria e Geraldo, e ao meu irmão Marcelo. 
"A prisão não são as grades, e a liberdade não é a rua; existem homens presos na rua e livres na prisão. É uma questão de consciência."

Ghandi. 


\section{AGRADECIMENTOS}

Agradeço a Deus, pelo supremo fenômeno que é a vida.

Ao Prof. Dr. Edson Luiz Silva pela disponibilidade em sempre colaborar com o trabalho, excelente orientação e dedicação ostensiva.

A todos aqueles que tanto amo, Marília, Bia, Jú, Nara, Janaína Braz, João Netto e que pacientemente esperaram meu regresso.

Aos queridos amigos de Maceió, Júnior Hermes, Flavinho, Sílvia, Eliane, Juninho e tantos outros que certamente sempre emanaram algum pensamento positivo, e que torceram pra que tudo acabasse, e bem.

Aos amigos que fizeram parte da minha vida durante o período que estive em São Carlos, e que certamente ajudaram a suportar este tempo com mais alegria, Curió, Camilinha, Dani Trivella, Lissa, Andrey, Shida, Joel, Miquinho, e a todos os outros que estiveram comigo.

Ao Eduardo Lucena, desde o início pessoa fundamental no meu trabalho, ainda com o aprendizado das técnicas laboratoriais até o fechamento da minha dissertação. Pessoa a quem desejo profundamente muita felicidade e sucesso na vida. Muito Obrigada!

Um agradecimento muito especial a minha querida amiga Juliana, cuja amizade e consideração jamais esquecerei. Amiga de fundamental importância que desejo que faça parte da minha vida para sempre.

A técnica Elô Pozzi, pela paciência, nas exaustivas tentativas de realização dos testes de atividade desnitrificante. Obrigada pela paciência e boa vontade. 
Ao técnico Oscar da Silva, pela construção do reator e pela excelência em todos os serviços prestados durante o desenvolvimento do trabalho.

Ao Sr. Nelson Gallo do Instituto de Física da Universidade de São Carlos, pelos exames microbiológicos com microscopia eletrônica de varredura.

Ao Prof. Titular Eugênio Foresti, pelo carinho e generosidade e pelas riquíssimas contribuições que facilitaram substancialmente a conclusão deste trabalho.

Ao meu amigo Prof. Márcio Barboza, pela confiança jamais questionada, e especialmente pela grande amizade construída ao longo destes anos.

Aos demais professores da UFAL que contribuíram com a minha formação, sobretudo a Prof ${ }^{a}$. Nélia Callado pela orientação na graduação e Prof ${ }^{a}$. Rosângela Sampaio pela força e grande amizade.

Aos colegas do LCA II, alguns, por me ensinar mesmo que muitas vezes de maneira inconsciente, o sentido do profissionalismo, e principalmente o significado de uma virtude tão magnífica; a paciência.

A Danni pela força na cromatografia e a Tininha pelas análises microscópicas.

Ao CNPq pelo auxílio financeiro e a FAPESP e pelo investimento no Laboratório de Controle Ambiental II do Departamento de Engenharia Química da UFSCar. 


\section{RESUMO}

OMENA, S. P. F. Remoção de fenol em reator anaeróbio de leito fluidificado sob condições desnitrificantes. 2008. Dissertação (Mestrado) - Escola de Engenharia, Universidade de São Paulo, São Carlos, 2008.

Este trabalho teve como objetivo geral a caracterização de um sistema de tratamento biológico de remoção de fenol em reator anaeróbio de leito fluidificado utilizando o nitrato como aceptor final de elétrons. O reator foi construído em acrílico transparente, com dimensões equivalentes a $190 \mathrm{~cm}$ de altura e 5,3 cm de diâmetro interno, totalizando um volume de 4192 $\mathrm{cm}^{3}$, dos quais cerca de $44 \%\left(1831 \mathrm{~cm}^{3}\right)$ foram ocupados pelo meio suporte, na situação de leito fixo. Para imobilização da biomassa foram utilizadas partículas de poliestireno, que foram previamente ativadas através de ataque ácido, com o intuito de aumentar a rugosidade e a porosidade da superfície do material, facilitando a aderência da biomassa ao meio suporte. O reator foi inoculado com lodo proveniente de reator UASB, responsável pelo tratamento de despejos de suinocultura. A realização do experimento foi dividida em cinco fases, que foram alteradas de acordo com o desempenho e a estabilidade do sistema diante do aumento das concentrações de fenol e nitrato. As concentrações médias de fenol afluente estudadas foram de 52, 107, 201, 335 e $518 \mathrm{mg} . \mathrm{L}^{-1}$, de maneira que não foi detectada presença de fenol no efluente para concentrações de até $335 \mathrm{mg} . \mathrm{L}^{-1}$. A eficiência de remoção reduziu-se para aproximadamente $70 \%$, quando foi operado com concentrações de fenol afluente superiores a $500 \mathrm{mg} . \mathrm{L}^{-1}$. A relação entre carbono (proveniente exclusivamente do fenol) e $\mathrm{N}-\mathrm{NO}_{3}$ foi aproximadamente 1, portanto, as concentrações médias afluentes de $\mathrm{N}-\mathrm{NO}_{3}$ testadas foram equivalentes a 45, 79, 157, 260 e $362 \mathrm{mg} . \mathrm{L}^{-1}$, cujas eficiências de remoção de nitrogênio foram de $94 \%, 89 \%, 86 \%, 79 \%$ e $51 \%$, respectivamente. $\mathrm{O}$ pH efluente variou entre 7,64 e 8,35, estando de acordo com sistemas que realizam o processo de desnitrificação. Em geral, cerca de 3,8 g DQO foi consumido por grama de $\mathrm{N}$ - $\mathrm{NO}_{3}$ removido. Não foi observado acúmulo de nitrito no sistema, considerando que o valor médio da concentração efluente foi de 1,5 mg. $\mathrm{L}^{-1}$ de $\mathrm{N}-\mathrm{NO}_{2}$ para todo período de operação. O experimento teve duração de 162 dias, nos quais o sistema mostrou resultados satisfatórios para redução de carbono e nitrogênio, mesmo quando operado com elevadas concentrações de fenol e nitrato.

Palavras - Chave: Processo anaeróbio, Processo anóxico, fenol, nitrogênio, desnitrificação, reator anaeróbio de leito fluidificado. 


\begin{abstract}
OMENA, S. P. F. Phenol removal an anaerobic fluidized bed reactor under denitrifying conditions. 2008. Dissertation - School of Engineering of São Carlos, Department of Hydraulics and Sanitation, University of São Paulo, São Carlos.
\end{abstract}

This work aimed the general characterization of a phenol removal biological treatment system in an anaerobic fluidized bed reactor using nitrate as the final electron acceptor. The reactor was built in transparent acrylic, with equivalent dimensions of $190 \mathrm{~cm}$ height and $5.3 \mathrm{~cm}$ intern diameter, resulting in $4,192 \mathrm{~cm}^{3}$ volume, which $44 \%$ were occupied by the support medium in a fix bed situation. Polystyrene particles were used to immobilize biomass, these particles were previously activated through acid attack, in order to increase materials roughness and superficial porosity, facilitating biomass adherence to the support medium. The reactor was inoculated with sludge from UASB reactor, responsible for swine culture effluent treatment. The experiment was divided in five phases, which were modified according to system performance and stability under the increase of phenol and nitrate concentrations. The mean phenol affluent concentrations studied were: $52,107,201,335$ and $518 \mathrm{mg} . \mathrm{L}^{-1}$, so that no phenol was detected in effluent in concentrations bellow $335 \mathrm{mg} . \mathrm{L}^{-1}$. The removal efficiency decreased to about $70 \%$ for affluent phenol concentrations over $500 \mathrm{mg} . \mathrm{L}^{-1}$. Carbon (exclusively from phenol) and $\mathrm{N}-\mathrm{NO}_{3}$ ratio was nearly 1, therefore the $\mathrm{N}-\mathrm{NO}_{3}$ mean affluent concentrations tested were equivalent to 45, 79, 157, 260 e $362 \mathrm{mg} . \mathrm{L}^{-1}$, whose nitrogen removal efficiency were $94 \%, 89 \%, 86 \%, 79 \%$ e $51 \%$, respectively. Effluent pH varied between 7.64 and 8.35, in agreement with denitrification process systems. In general, around $3.8 \mathrm{~g}$ DQO were consumed per gram of removed $\mathrm{N}-\mathrm{NO}_{3}$. No nitrite accumulation was observed in the system, considering that the mean effluent concentration was $1.5 \mathrm{mg} . \mathrm{L}^{-1}$ de $\mathrm{N}-\mathrm{NO}_{2}$ to all operation period. Experiment lasted 162 days, during this time the system showed satisfactory results for carbon and nitrogen reduction, even when operated with high phenol and nitrate concentrations.

Key words: Anaerobic process, anoxic process, phenol, nitrogen, denitrification, anaerobic fluidized bed reactor. 


\section{LISTA DE FIGURAS}

Figura 3.1 - Esquema da rota metabólica aeróbia da degradação do fenol.............................

Figura 3.2 - Esquema da rota metabólica anaeróbia da degradação do fenol ........................ 11

Figura 3.3 - Degradação do 4 - Hidroxibenzoato ........................................................ 12

Figura 3.4 - Interação entre metanogênese e desnitrificação na degradação do fenol............. 26

Figura 4.1 - Esquema ilustrativo do aparato experimental ................................................ 45

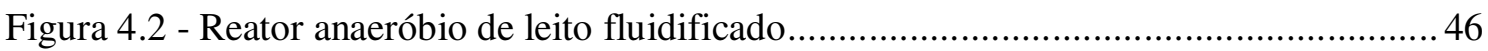

Figura 4.3 - Ponto de coleta do biogás e do efluente, indicado pela seta no headspace.......... 47

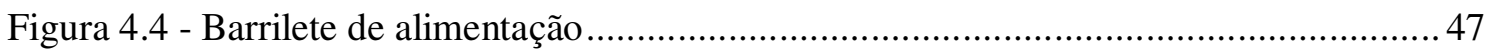

Figura 4.5 - Partículas de poliestireno no reator de leito fluidificado. ................................ 48

Figura 4.6 - Fluxograma da água residuária, referente ao período de adaptação....................52

Figura 5.1 - Variação da concentração de fenol durante o período de adaptação ...................57

Figura 5.2 - Variação da concentração de nitrato durante o período de adaptação..................58

Figura 5.3 - Variação temporal das concentrações de fenol afluente (๘), efluente (») e de

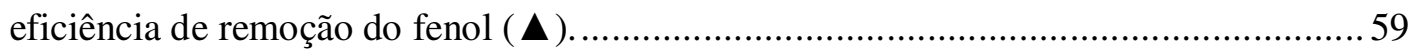

Figura 5.4 - Variação da vazão medida através da coleta do efluente (४). .......................... 64

Figura 5.5 - Variação da TCF de fenol (₫) e eficiência de redução de fenol( $\boldsymbol{(})$ ) .................. 65

Figura 5.6 - Variação temporal das concentrações de DQO afluente (•), efluente (४) e de

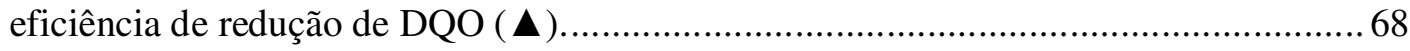

Figura 5.7 - Variação temporal das concentrações de nitrato afluente (๘), efluente ( $\diamond)$ e de

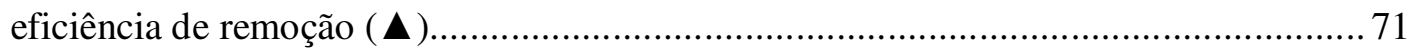

Figura 5.8 - Variação temporal da taxa de carregamento de nitrogênio aplicada afluente (匹), e

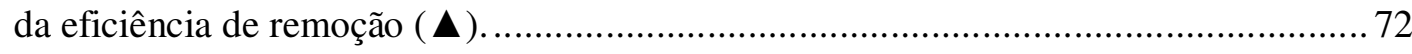

Figura 5.9 - Variação temporal das concentrações $\mathrm{N}-\mathrm{NO}_{2}$ do efluente (४)......................... 75 
viii

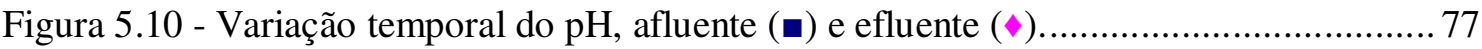

Figura 5.11 - Variação das concentrações de alcalinidade afluente (๘) e efluente (४) ...........78

Figura 5.12 - Variação das concentrações de ácidos voláteis afluente (๘), efluente (४)........ 80

Figura 5.13 - (a) bacilos retos; (b) imagem panorâmica mostrando biofilme bastante aderido a

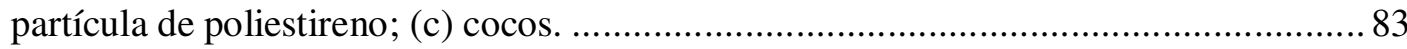

Figura 5.14 - (a) bacilos ovalados; (b) cocos; (c) bacilos retos ......................................... 85

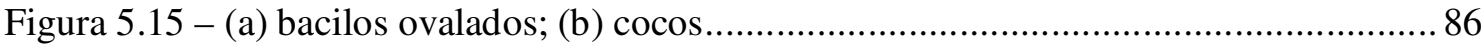

Figura 5.16 - (a) bacilos ovalados; (b) cocos; (c) bacilos; (d) microrganismos envolvidos em

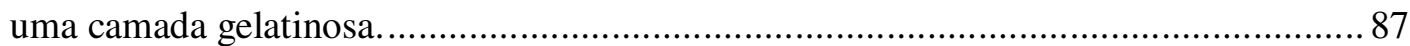

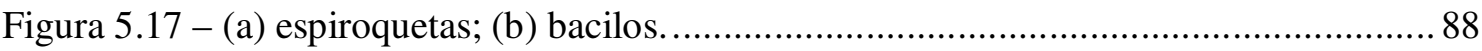

Figura 5.18 - (a) bacilos curvos e (b) microrganismos envolvidos em matriz polimérica...... 89

Figura 5.19 - Variação das concentrações de sólidos suspensos voláteis no efluente ( $)$ (.......91

Figura 5.20 - Relação entre SSV/SST no efluente ( $)$. .................................................. 94 


\section{LISTA DE TABELAS}

Tabela 3.1 - Propriedades físico - químicas do fenol................................................... 6

Tabela 3.2 - Microrganismos capazes de degradar fenol via anaeróbia ............................. 10

Tabela 3.3 - Formação de ácidos benzóico através de fenol e isômeros de cresol.................. 18

Tabela 3.4 - Faixas de variação de parâmetros operacionais de alguns reatores anaeróbios... 35

Tabela 3.5 - Características de diferentes tipos de reatores. ........................................... 39

Tabela 3.6 - Comparação de alguns estudos sobre desnitrificação utilizando RALF............. 39

Tabela 4.1 - Composição da solução nutriente..................................................................... 50

Tabela 4.2 - Composição da solução traço de metais ........................................................ 50

Tabela 4.3 - Fases de operação do RALF.................................................................. 53

Tabela 5.1 - Valores médios de concentração e remoção de fenol, vazão, TDH e altura de

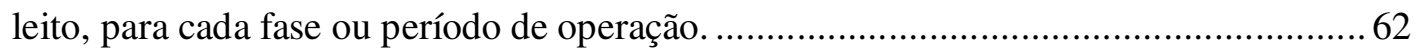

Tabela 5.2 - Descrição das principais características de estudos na degradação do fenol em

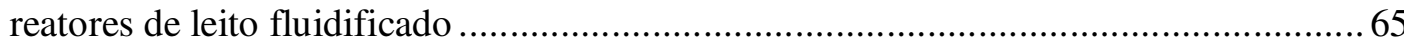

Tabela 5.3 - Valores médios de DQO e de eficiência de redução, conforme as mudanças de fase.

Tabela 5.4 - Valores médios das concentrações de $\mathrm{N}$ - $\mathrm{NO}_{3}$, eficiência de redução de nitrogênio, relação $\mathrm{C} / \mathrm{N}-\mathrm{NO}_{3}$ e DQO/N - $\mathrm{NO}_{3}$, conforme as mudanças de fases.

Tabela 5.5 - Pesquisas envolvidas na degradação do fenol, utilizando $\mathrm{NO}_{3}$ como aceptor final de elétrons. 71

Tabela 5.6 - Valores teóricos de alcalinidade medidos no efluente do reator. 80 


\section{LISTA DE SÍMBOLOS E ABREVIATURAS}

\begin{tabular}{|c|c|}
\hline $4-\mathrm{OHBz}$ & 4 - Hidrobenzoato \\
\hline $\mathrm{A} / \mathrm{M}$ & Relação alimento/microrganismo \\
\hline $\mathrm{AB}$ & Alcalinidade Bicarbonato $\left(\mathrm{ML}^{-3}\right)$ \\
\hline APHA & American Public Health Association \\
\hline ATP & Adenosina trifosfato \\
\hline ATSDR & Agency for Toxic Substances and Disease Registry \\
\hline AVT & Ácidos Voláteis Totais $\left(\mathrm{ML}^{-3}\right)$ \\
\hline Benzoil - CoA & Benzoil - Coenzima A \\
\hline BRS & Bactéria Redutora de Sulfato \\
\hline BTEX & Benzeno, Tolueno, Etilbenzeno e Xileno \\
\hline $\mathrm{C}_{2}$ & Grupo carbonila, formado por um átomo de carbono e um de oxigênio. \\
\hline $\mathrm{C}_{6} \mathrm{H}_{5} \mathrm{OH}$ & Fórmula estrutural do fenol \\
\hline $\mathrm{CaCO}_{3}$ & Bicarbonato de cálcio \\
\hline CETESB & Companhia de Tecnologia de Saneamento Ambiental \\
\hline $\mathrm{C} / \mathrm{N}$ & Relação entre carbono e nitrogênio \\
\hline $\mathrm{COOH}$ & Grupo funcional carboxila \\
\hline CSTR & Reator Tanque de Mistura Completa \\
\hline DNF & Dinitrofenol \\
\hline DQO & Demanda Química de Oxigênio $\left(\mathrm{ML}^{-3}\right)$ \\
\hline $\mathrm{DQO} / \mathrm{N}-\mathrm{NO}_{3}$ & Relação entre a DQO e Nitrogênio sob a forma de nitrato \\
\hline EPS & Poliméricas Extracelulares \\
\hline HMDS & Hexametildisilazani \\
\hline LAS & Alquilbenzeno linear sulfonado \\
\hline
\end{tabular}




\begin{tabular}{|c|c|}
\hline $\mathrm{MCP}$ & Monocloninado de Fenol \\
\hline MEV & Microscópio Eletrônico de Varredura \\
\hline $\mathrm{mM}$ & mili - molar \\
\hline $\mathrm{mV}$ & mili - Volts \\
\hline $\mathrm{N}_{2}$ & Gás Nitrogênio \\
\hline $\mathrm{NAD}^{+}$ & Nicotinamida adenina dinucleotídeo (forma oxidada) \\
\hline NADH & Nicotinamida adenina dinucleotídeo (forma reduzida) \\
\hline $\mathrm{NADP}^{+}$ & Nicotidamina adenina dinucleotide fosfato \\
\hline NF & Nitrofenol \\
\hline $\mathrm{NH}_{3}$ & gás amoníaco \\
\hline $\mathrm{NH}_{4}^{+}$ & íon amônio \\
\hline $\mathrm{N}-\mathrm{NO}_{2}$ & Nitrogênio sob a forma de nitrito \\
\hline $\mathrm{N}-\mathrm{NO}_{3}$ & Nitrogênio sob a forma de nitrato \\
\hline${ }^{\circ} \mathrm{C}$ & Graus Celsius \\
\hline OD & Oxigênio Dissolvido $\left(\mathrm{ML}^{-3}\right)$ \\
\hline $\mathrm{OH}^{-}$ & Hidroxila \\
\hline PET & Polietileno tereftalato \\
\hline $\mathrm{pH}$ & Potencial Hidrogeniônico \\
\hline $\mathrm{ppb}$ & partes por bilhão \\
\hline ppm & partes por milhão \\
\hline PVC & Cloreto de polivinil \\
\hline RALF & Reator Anaeróbio de Leito Fluidificado \\
\hline rpm & Rotações por minuto \\
\hline S & Concentração de substrato ou nutriente limitante $\left(\mathrm{ML}^{-3}\right)$ \\
\hline SBR & Reator de Batelada Seqüencial \\
\hline
\end{tabular}


SSV

Sólidos Suspensos Voláteis $\left(\mathrm{ML}^{-3}\right)$

SVT

Sólidos Voláteis Totais $\left(\mathrm{ML}^{-3}\right)$

TCO

Taxa de Carregamento Orgânico $\left(\mathrm{ML}^{-3} \cdot \mathrm{T}^{-1}\right)$

TCF

Taxa de Carregamento de Fenol $\left(\mathrm{ML}^{-3} \mathrm{~T}^{-1}\right)$

$\mathrm{TDH}$

Tempo de Detenção Hidráulica (T)

TDHe

Tempo de Detenção Hidráulica efetivo (T)

TRC

Tempo de Retenção Celular (T)

UASB

Reator Anaeróbio de Manta de Lodo

UNESP

Universidade Estadual Paulista

Vs

Velocidade Superficial do meio suporte no leito do reator fluidificado $\left(\mathrm{LT}^{-1}\right)$ 


\section{SUMÁRIO}

RESUMO $\quad$ v

ABSTRACT

LISTA DE FIGURAS vii

LISTA DE TABELAS ix

LISTA DE SÍMBOLOS E ABREVIATURAS X

1. INTRODUÇÃO 1

2. OBJETIVOS 4

2.1. OBJETIVOS ESPECÍFICOS 4

3. REVISÃO BIBLIOGRÁFICA

3.1. ASPECTOS GERAIS SOBRE O FENOL

3.2. ROTAS METABÓLICAS NA DEGRADAÇÃO BIOLÓGICA DO FENOL 7

$\begin{array}{lc}\text { 3.2.1. Rota aeróbia } & 8\end{array}$

3.2.2. Rota anaeróbia 9

3.3. MICRORGANISMOS ENVOLVIDOS NA DEGRADAÇÃO DO FENOL 13

3.4. ACEPTORES DE ELÉTRONS 16

3.5. DESNITRIFICAÇÃO 18

3.6. REMOÇÃO DE FENOL SOB CONDIÇÕES DESNITRIFICANTES 25

3.7. RELAÇÃO C/N 31

3.8. REATORES DE LEITO FLUIDIFICADO 34

3.8.1. Remoção de fenol em reator de leito fluidificado 40

3.9. CONSIDERAÇÕES FINAIS DA REVISÃO BIBLIOGRÁFICA 43

4. MATERIAL E MÉTODOS 45

4.1. REATOR ANAERÓBIO DE LEITO FLUIDIFICADO $\quad 45$ 
$\begin{array}{lll}\text { 4.2. INÓCULO } & 48\end{array}$

4.3. SUPORTE PARA IMOBILIZAÇÃO DA BIOMASSA 48

4.4. ÁGUA RESIDUÁRIA SINTÉTICA $\quad 49$

4.5. ADAPTAÇÃO DO INÓCULO À ÁGUA RESIDUÁRIA E INÍCIO DA OPERAÇÃO 51

4.6. MÉTODOS ANÁLITICOS 53

4.6.1. Caracterização microbiológica do biofilme anaeróbio 54

4.6.2. Determinação da produção de metano 55

5. RESULTADOS E DISCUSSÃO 56

5.1. ADAPTAÇÃO DA BIOMASSA A ÁGUA RESIDUÁRIA SINTÉTICA 56

5.2. DEGRADAÇÃO ANAERÓBIA DO FENOL EM REATOR DE LEITO

FLUIDIFICADO 58

5.3. DESNITRIFICAÇÃO $\quad 69$

5.4. DEMAIS PARAMETROS MONITORADOS 76

5.5. CARACTERIZAÇÃO MORFOLÓGICA DA BIOMASSA E AVALIAÇÃO DA ADESÃO DO BIOFILME AS PARTÍCULAS DE POLIESTIRENO 82

6. CONCLUSÕES

7. RECOMENDAÇÕES 98

REFERÊNCIAS BIBLIOGRÁFICAS

$\begin{array}{ll}\text { APÊNDICE } & 108\end{array}$ 


\section{INTRODUÇÃO}

O fenol é um composto orgânico presente em efluentes de diversas atividades industriais, tais como química, têxtil, plástica, farmacêutica, metalúrgica, refinarias de óleo, produção de pesticidas, papéis e explosivos, recalcitrantes à biodegradação e tóxicos à maioria dos microrganismos (ASSALIN, 2006).

A emissão de água residuária contendo fenol pode comprometer seriamente a vida aquática, devido à sua toxicidade e solubilidade em água. Portanto, se faz necessário a remoção desse composto, antes do seu descarte nos corpos receptores. A Resolução 357 da CONAMA (2005) limita o lançamento de efluentes contendo fenol em apenas $0,5 \mathrm{mg} . \mathrm{L}^{-1}$ $\mathrm{C}_{6} \mathrm{H}_{5} \mathrm{OH}$.

O tratamento de águas residuárias contendo fenol tem sido realizado por diversos processos físico - químicos, como extração por solventes, adsorção, tratamento eletrolítico, emprego de enzimas, além dos mais variados mecanismos de oxidação avançada. No entanto, esses processos podem elevar os custos do tratamento, além da possível geração de subprodutos perigosos. Sendo assim, a aplicação de processos biológicos é uma alternativa interessante, sobretudo por apresentar custos de operação relativamente baixos e possibilidade da completa mineralização do fenol.

Dentre os processos biológicos, os que são realizados via aeróbia em geral possuem eficiências mais elevadas que os anaeróbios. No entanto, possuem como desvantagens a significativa produção de lodo e a necessidade de longos períodos de aeração, implicando em elevados custos com energia.

Os processos anaeróbios podem ser realizados por microrganismos fermentantivos, fotossintéticos, ou por microrganismos que realizam respiração anaeróbia utilizando um 
aceptor inorgânico de elétrons, a exemplo do metano, íon ferro, sulfato ou nitrato. Por ser comum a presença de nitratos em efluentes industriais que contêm fenol, e pelo fato de que a redução do nitrato necessita de um doador de elétrons, torna-se então uma opção atrativa a remoção simultânea de fenol e nitrato.

Diversos estudos conduzem à aplicação do tratamento biológico de compostos orgânicos e inorgânicos em reatores bioquímicos, dentre os quais merecem destaque os de alta taxa. Estes sistemas utilizam uma pequena área em planta e oxidam a matéria orgânica com alta eficiência, apresentam baixo consumo relativo de energia e baixa produção de lodo.

Dentre os reatores de alta taxa, o reator de leito fluidificado é apontado como uma alternativa promissora no tratamento de compostos recalcitrantes. Neste tipo de reator, a maior parte da biomassa está aderida como biofilme nas partículas inertes, proporcionando maior contato superficial entre as biopartículas (partículas suporte + biofilme) e a água residuária, minimizando as resistências difusionais e favorecendo a transferência de massa.

Assim, pesquisas recentes evidenciam a possibilidade de remoção biológica do fenol como fonte de carbono e energia, utilizando nitrato como aceptor terminal de elétrons, (THOMAS et al., 2002; SARFARAZ et al., 2004; ZHU et al., 2006), e o emprego de reator anaeróbio de leito fluidificado (RALF) na degradação anaeróbia do fenol (SANCINETTI, 2004; SADER, 2005; AMORIM, 2007). Dentre os diversos fatores que interferem no desempenho do RALF, sobretudo quando empregado para remoção de fenol, destacam-se o tipo de inóculo (SANCINETTI, 2004), meio suporte e formação de biofilme (SADER, 2005), tipo de adaptação e estratégia de partida (AMORIM, 2007). No entanto, ainda são bastante escassos os relatos de remoção de fenol aliado ao processo de desnitrificação utilizando o reator de leito fluidificado. 
Neste contexto, esta pesquisa tem como objetivos gerais, o emprego de consórcios de microrganismos anaeróbios com potencial de degradar eficientemente fenol sob condições desnitrificantes, utilizando reator de leito fluidificado. 


\section{OBJETIVOS}

Este trabalho teve como objetivo geral a caracterização de um sistema de tratamento biológico de remoção de fenol em reator anaeróbio de leito fluidificado preenchido com partículas de poliestireno, operado sob condições desnitrificantes.

\subsection{OBJETIVOS ESPECÍFICOS}

a) Análise do potencial da cultura mista, obtida através de lodo de suinocultura, na remoção simultânea de fenol e $\mathrm{N}$ - $\mathrm{NO}_{3}$;

b) Avaliação da estabilidade de operação e resultados de eficiência sob aumento progressivo de fenol e $\mathrm{N}-\mathrm{NO}_{3}$;

c) Análise da formação e desenvolvimento do biofilme no meio suporte. 


\section{REVISÃO BIBLIOGRÁFICA}

\subsection{ASPECTOS GERAIS SOBRE O FENOL}

O desenvolvimento industrial tem implicado em diminuição das reservas de petróleo e de gás natural. Os processos de conversão de carvão (liquefação e gaseificação) são alternativas promissoras para a produção de combustíveis líquidos e gasosos. A conversão de carvão produz compostos tóxicos, que além de serem dificilmente biodegradáveis, também inibem a degradação de outros constituintes que possam vir estar presentes na água residuária. A maioria dos compostos orgânicos presente no processo de conversão de carvão é principalmente o fenol, metil - fenol e $\mathrm{C}_{2}$ - fenol (RAMAKRISHNAN; GUPTA, 2006).

Com elevado potencial poluidor, o fenol pode estar igualmente presente em efluentes de diversos outros tipos de indústrias, tais como; na fabricação de aço, plástico, indústria farmacêutica, têxtil, (THOMAS et al., 2002), é também usado na preparação de solventes, pesticidas e herbicidas (KARLSSON et al., 1999).

O fenol é um composto orgânico amplamente aplicado na produção de resinas sintéticas, a exemplo das poliamidas, fenólicas (materiais de construção para automóveis e eletrodomésticos) e epóxicas (adesivos, policarbonatos para a fabricação de vasilhames de refrigerantes) (ROJAS, 2001).

O fenol é um hidrocarboneto aromático monosubstituído, incolor quando puro, exala um cheiro forte adocicado e ácido, que pode ser detectado pela maioria das pessoas em concentrações de apenas 40 ppb no ar e cerca de 1 - 8 ppm em água (ATSDR, 2006). O fenol evapora mais lentamente que a água, é solúvel e comburente. A Tabela 3.1 apresenta algumas informações adicionais sobre o fenol. 
Tabela 3.1 - Propriedades físico - químicas do fenol.

Sinônimos

Nomes comerciais

Ponto de fusão, ${ }^{\circ} \mathrm{C}$

Ponto de ebulição, ${ }^{\circ} \mathrm{C}$

Pressão de vaporização, a $25^{\circ} \mathrm{C}$

Densidade $\left(20^{\circ} \mathrm{C}\right)$, relativa a $\mathrm{H}_{2} \mathrm{O}\left(4^{\circ} \mathrm{C}\right)$

Solubilidade em água $\left(25^{\circ} \mathrm{C}\right)$, g. $\mathrm{L}^{-1}$.

Limite de odor

Peso molecular

Fórmula empírica

Fórmula estrutural
Benzenol, hidroxibenzeno, monofenol, oxibenzeno, álcool fenil, fenil hidratado, hidróxido fenil Ácido carbólico, ácido fénico, álcool fénico

43

181,8

0,3513

1,0576

87

$0,047 \mathrm{ppm}\left(0,18 \mathrm{mg} \cdot \mathrm{m}^{-3}\right)$

94,12

$\mathrm{C}_{6} \mathrm{H}_{6} \mathrm{O}$

Fonte: U.S. EPA, 2002.

O fenol está entre os 50 produtos químicos mais produzidos em grande escala, nos Estados Unidos (ATSDR, 2006). Em geral, suas concentrações em efluentes industriais estão compreendidas entre 10 e $17 \times 10^{3} \mathrm{mg} . \mathrm{L}^{-1}$, variando principalmente de acordo com o tipo de indústria. Em geral a contribuição de DQO (Demanda Química de Oxigênio) dos compostos fenólicos nesses efluentes está na faixa de 40\% a 80\% da DQO total (VEREESH; KUMAR; MEHROTRA, 2005).

Além dos processos industriais, algumas fontes naturais também são responsáveis pela produção de fenóis, contudo, em concentrações muito menores quando comparadas com as encontradas em atividades antropogênicas (VAN SCHIE; YOUNG, 2000).

Em ambiente natural, o fenol pode ser encontrado em plantas, a exemplo das estruturas de lignina e alguns compostos de defesa que são usados pelos herbívoros 
(KARLSSON et al., 1999). Os fenóis também são intermediários na biodegradação de polímeros naturais que possuem anéis aromáticos, como taninas e ácidos precursores de amino - aromáticas (VAN SCHIE; YOUNG, 1998).

O fenol é tóxico aos microrganismos, pois possui habilidade de romper a membrana lipídica e, sendo esta a única barreira entre o citoplasma e o ambiente, a perda da integridade osmótica conduz à morte celular (VAN SCHIE; YOUNG, 2000).

Pessoas que ingerem água contaminada com fenol apresentam sintomas como diarréia, náuseas e dores na garganta, além de expelir urina escura. Estima-se que a dose letal do fenol em adultos varia entre $1 \mathrm{~g}\left(14 \mathrm{mg} \cdot \mathrm{kg}^{-1}\right.$, assumindo um adulto pesando $70 \mathrm{~kg}$ ) até $65 \mathrm{~g}$ (930 mg. $\left.\mathrm{kg}^{-1}\right)$, (U.S. EPA, 2002).

A eliminação dos compostos fenólicos pode ser feita através de diversos processos físico - químicos, tais como: adsorção com carvão ativado, extração por solventes, oxidação química, tratamentos enzimáticos (THOMAS et al., 2002). No entanto, processos biológicos são preferíveis em função da economia e da baixa probabilidade de formação de subprodutos perigosos (BAI et al., 2007).

\subsection{ROTAS METABÓLICAS NA DEGRADAÇÃO BIOLÓGICA DO FENOL}

Embora não faça parte dos objetivos deste trabalho, a determinação dos compostos intermediários produzidos durante a degradação biológica do fenol, serão apresentados a seguir, de maneira bastante sintetizada, alguns aspectos referentes ao metabolismo do fenol, a fim de elucidar melhor alguns aspectos sobre este composto aromático. 
Tradicionalmente, tratamentos biológicos aeróbios têm sido empregados no tratamento de compostos fenólicos em águas residuárias, entretanto, esses métodos necessitam de grande quantidade de energia e são caracterizados por alta produção de lodo (SARFARAZ et al., 2004). A via anaeróbia torna-se, então, uma opção atrativa, pois apresenta resultados bastante satisfatórios, embora, como desvantagens, tenha processos metabólicos mais lentos e de maneira geral, atinjam eficiências de remoção menores que os aeróbios.

O metabolismo aeróbio é caracterizado pelo uso extensivo de oxigênio molecular que é essencial para hidroxilação e para clivagem do anel aromático. O anaeróbio requer compostos aromáticos solúveis, com baixo peso molecular, utilizando assim, uma rota completamente diferente do aeróbio, pois, na maioria dos casos o composto é reduzido e posteriormente o anel é quebrado hidroliticamente (HARWOOD et al., 1998).

\subsubsection{Rota aeróbia}

O primeiro passo da rota metabólica aeróbia para biodegradação do fenol é a utilização do oxigênio molecular, pela enzima hidroxilase, para formação de um segundo grupo hidroxil na orto-posição. É formado então o catecol (1,2 - dihidroxilbenzeno) que, por sua vez, pode ser degradado por duas rotas distintas (orto ou meta) a depender do microrganismo envolvido no processo (VAN SCHIE; YOUNG, 2000).

$\mathrm{Na}$ rota orto, há clivagem do anel entre os dois grupos hidroxilas, através do catecol 1,2 - dihidrogenase formando o ácido cis, cis mucônico. Já pela rota meta, a quebra do anel ocorre adjacente aos dois grupos hidroxilas. A enzima catecol 2,3 - dihidroxigenase 
transforma o catecol para 2 - hidroximucônico. Os produtos finais formados em ambas as rotas são posteriormente metabolizadas no ciclo de Krebs (VAN SCHIE; YOUNG, 2000). A Figura 3.1 ilustra as possíveis rotas metabólicas na degradação aeróbia do fenol.

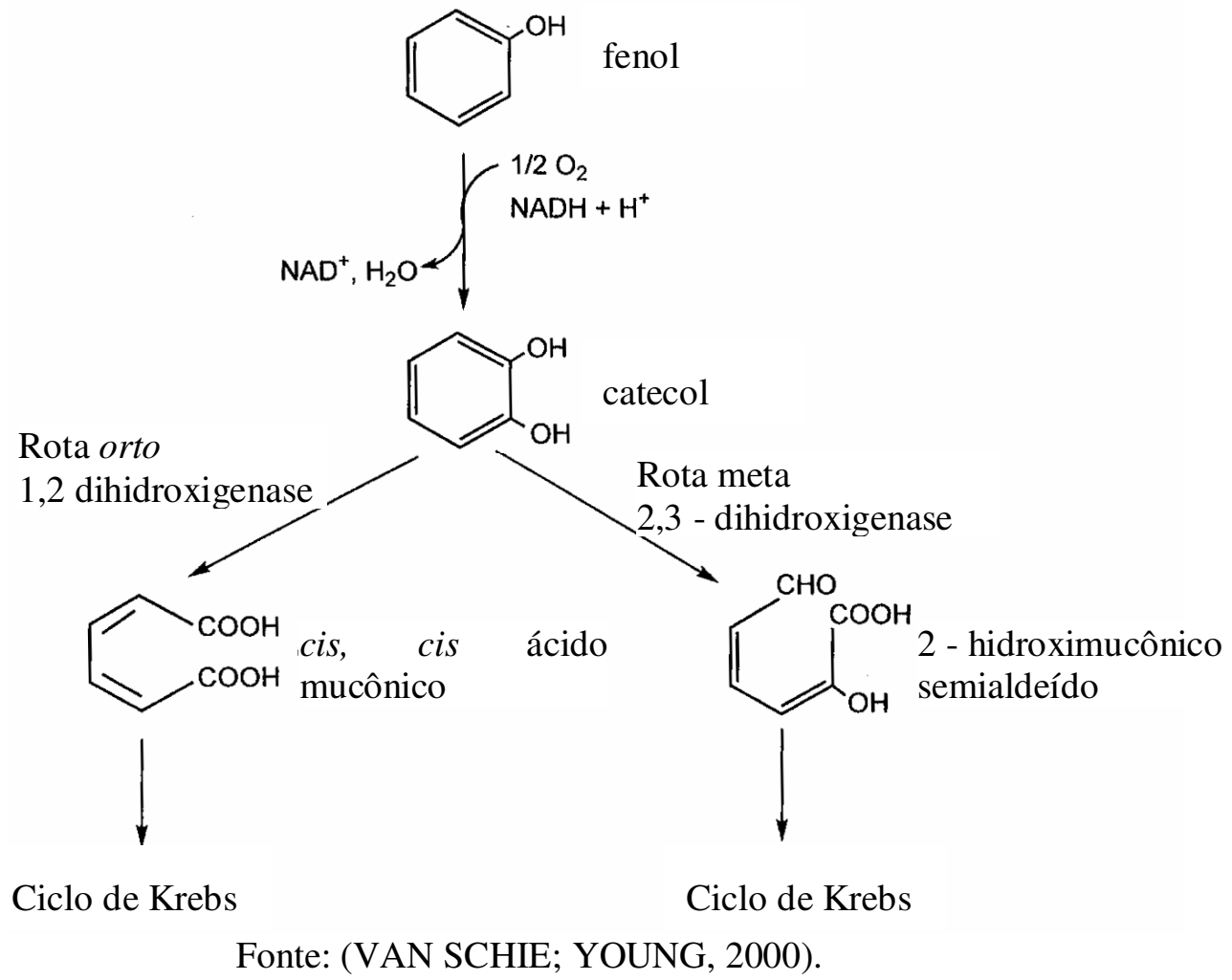

Figura 3.1 - Esquema da rota metabólica aeróbia da degradação do fenol

\subsection{2. $\quad$ Rota anaeróbia}

Na degradação anaeróbia de compostos aromáticos, a estratégia a ser seguida, para ativação e clivagem do anel, dependerá, essencialmente, se o processo é realizado por microrganismos anaeróbios fermentativos ou fototróficos (Tabela 3.2), que utilizam nitrato, 
íon férrico, sulfato ou carbonato como aceptores de elétrons. Até agora, maiores informações sobre a rota metabólica do fenol foram obtidas com microrganismos desnitrificantes.

Dependendo do potencial redox do aceptor de elétrons mais ou menos energia poderá ser conservada na respiração anaeróbia. Isto causa uma forte hierarquia, além de um gradiente espacial de organismos que competem pelo aceptor de elétrons que tem maior potencial redox. O oxigênio é o aceptor inorgânico com maior potencial $(+818 \mathrm{mV})$. Em seguida encontra-se o nitrato $(+433 \mathrm{mV})$, estendendo-se para, íons metálicos oxidados, como ferro ou $\mathrm{Mn}^{4+}(+200 \mathrm{mV})$, até sulfato ( - $\left.200 \mathrm{mV}\right)$ (HEIDER; FUCHS, 1997).

Tabela 3.2 - Microrganismos capazes de degradar fenol via anaeróbia.

\begin{tabular}{lc}
\hline Tipo do microrganismo & Espécies e linhagens \\
\hline Redutor de nitrato & Thauera aromatica K172 e S100 \\
Redutor de nitrato & Azoarcus sp. PbN1, ToN1 \\
Redutor de nitrato & Azoarcus sp. PHOO2, CR23, FLO5 \\
Redutor de sulfato & Desulfobacterium phenolicum \\
Redutor de sulfato & Desulfotomaculum sp. Groll \\
Redutor de sulfato & Desulfovibrio sp. \\
Redutor de ferro & Geobacter metallireducens GS15 \\
\hline
\end{tabular}

Fonte: (VAN SCHIE; YOUNG, 2000).

O primeiro passo para degradação do fenol utilizando nitrato como aceptor final de elétrons é a carboxilação na posição para, produzindo 4 - hidroxibenzoato (TSCHECH; FUCHS, 1987). O processo é realizado por uma enzima denominada de "fenol carboxilase" (VAN SCHIE; YOUNG, 2000). 
No entanto, Lack e Fuchs (1994) observaram que a enzima responsável pela carboxilação do fenol foi inativa, constatando que apenas o fenilfosfato (ácido fosfórico monofenil éster) foi realmente carboxilado. Os autores demonstraram que o primeiro produto formado detectado através do fenol foi o fenilfosfato e que, concomitante ao consumo deste, havia formação de 4 - hidroxibenzoato $(4-\mathrm{OHBz})$. O experimento foi realizado in vitro, sob condições desnitrificantes, com a linhagem Pseudomonas. A Figura 3.2 exibe o esquema de formação do 4 - OHBz.

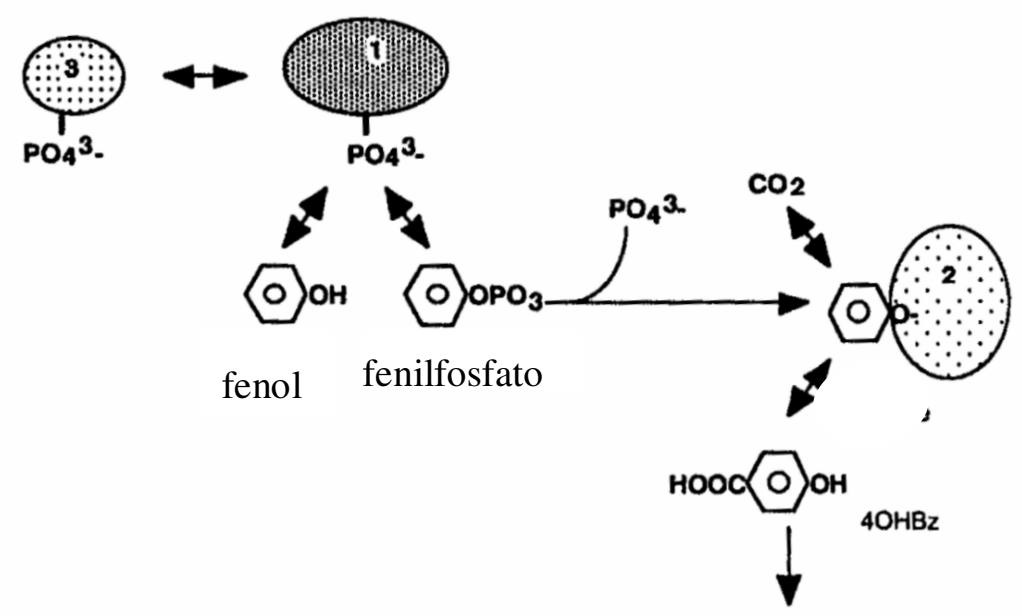

Fonte: (VAN SCHIE; YOUNG, 2000).

Figura 3.2 - Esquema da rota metabólica anaeróbia da degradação do fenol

Os principais intermediários produzidos pela maioria dos substratos aromáticos são: benzoil - CoA, resorcinol e floruglucinol. Assim, após a carboxilação do fenol, através da ativação da coenzima A, é iniciada a eliminação redutiva do hidroxi - substituinte para a forma de benzoil - CoA (REINEKE, 2001).A rota da degradação do benzoato (Figura 3.3), segue basicamente cinco fases: (1) tioesterificação da CoA, (2) hidratação/desoxigenação, (3) redução do anel, (4) quebra do anel e (5) $\beta$-oxidação da abertura do anel para acetil - CoA (VAN SCHIE; YOUNG, 2000). 


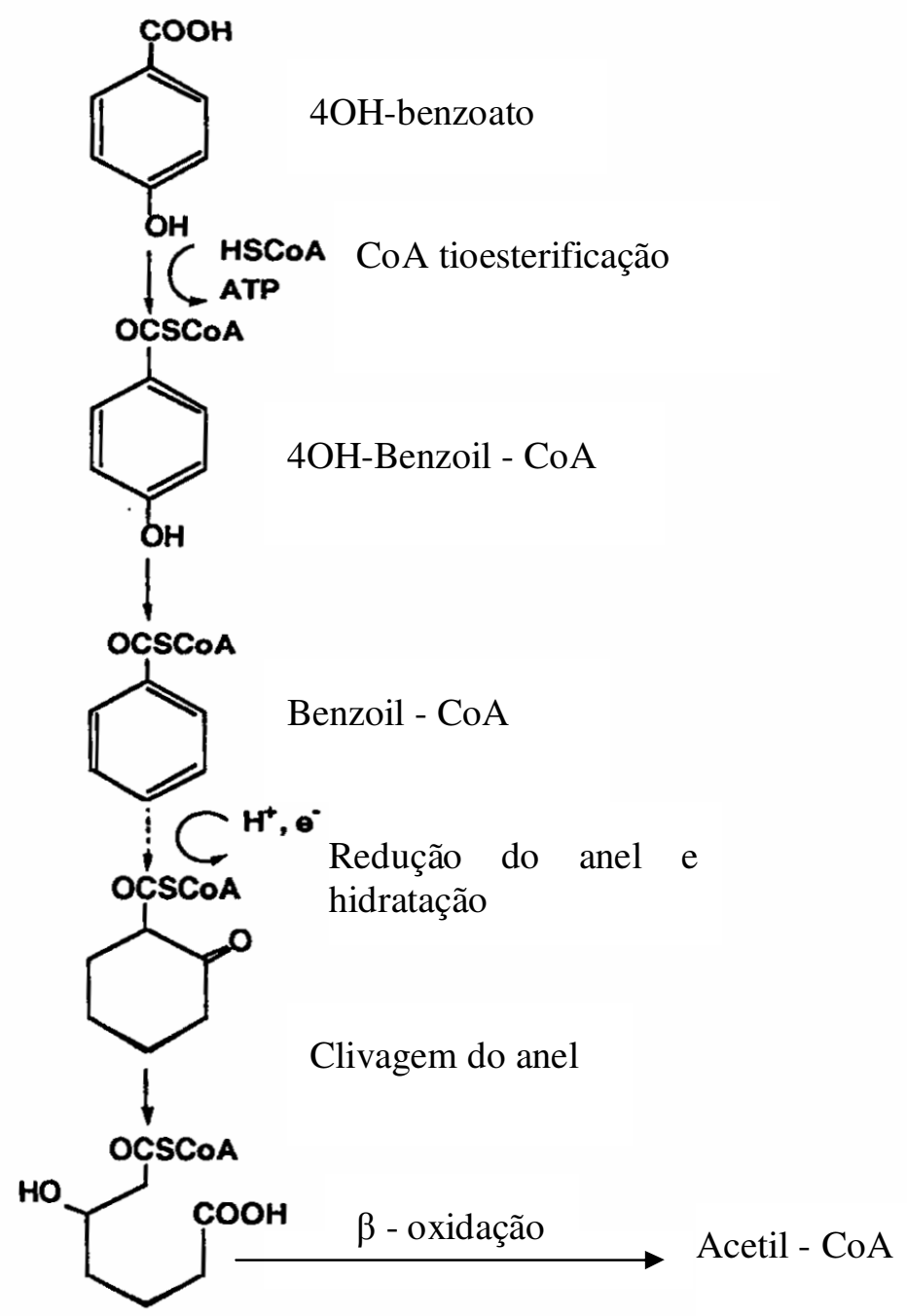

Fonte: (VAN SCHIE; YOUNG, 2000).

Figura 3.3 - Degradação do 4 - Hidroxibenzoato

Em suma, a tioesterificação do grupo carboxil é um mecanismo muito importante como ponto de entrada e transferência de elétrons. Contudo, ainda que a redução do benzoil CoA seja facilitada pela tioresterização da $\mathrm{CoA}$, o processo requer introdução de energia através de duas moléculas de ATP, uma para cada elétron introduzido. Os microrganismos redutores de nitrato podem recuperar energia através da ativação do substrato e pela redução do anel aromático favorecendo a clivagem do anel, o qual pode ser totalmente oxidado a $\mathrm{CO}_{2}$ (REINEKE, 2001). 


\subsection{MICRORGANISMOS ENVOLVIDOS NA DEGRADAÇÃO DO FENOL}

Apesar do fato de que o fenol pode estar presente em grande parte dos solos e sedimentos, poucos microrganismos capazes de degradar fenol foram isolados e caracterizados. Os microrganismos aeróbios têm sido descritos desde 1908, porém, apenas em 1986 foi encontrado o primeiro relato de bactéria responsável pela degradação do fenol em ambiente estritamente anaeróbio, denominada de Desulfobacterium phenolicum (VAN SCHIE; YOUNG, 1998).

Boopathy (1995) utilizando fenol como única fonte de carbono e energia, fez o isolamento de Bactérias Redutoras de Sulfato (BRSs). Durante o metabolismo do fenol, o produto final foi ácido acético, no qual para cada mol de fenol degradado dois moles de ácido foram produzidos. Como o ácido acético não foi totalmente degradado para $\mathrm{CO}_{2}$, o autor concluiu que as BRSs não tinham habilidade de degradar completamente compostos aromáticos como fenol, utilizando sulfato como aceptor final de elétrons.

São conhecidas diversas espécies de microrganismos que fazem redução do íon férrico, a maioria das subclasses $\gamma$ e $\delta$ de Proteobacteria. Após isolamento da Geobacter metallireducens, foi verificada oxidação para o fenol, tolueno, p-cresol, aldeídos aromáticos, álcoois e benzoato, no qual, $\mathrm{Fe}^{3+}$ é reduzido para $\mathrm{Fe}^{2+}$ (HEIDER; FUCHS, 1997).

Zhang et al. (2005) através dos grânulos formados na degradação metanogênica do fenol, realizaram a caracterização microbiológica, utilizando técnicas como Reação Polimérica em Cadeia (PCR), amplificação, Desnaturação do Gradiente em Gel por Eletroforese (DGGE), clonagem, seqüenciamento de DNA e Hibridização por Fluorescência In Situ (FISH). Os autores observaram que o lodo era composto de $26 \pm 6 \%$ de Eubacteria e $74 \pm 9 \%$ de metanogênicas, as quais, $54 \pm 6 \%$ eram acetotróficas Methanosaetaceae, $14 \pm 3 \%$ 
e $3 \pm 2 \%$ eram hidrogenotróficas sendo, Methanomicrobiales e Methanobacteriaceae, respectivamente.

Rodrigues (2006) estudou a viabilidade do uso do fungo Aspergillus niger em reator biológico para o tratamento de água residuária sintética contendo fenol. O trabalho foi realizado com dois tipos de reatores: em batelada e contínuos com escoamento ascendente. No experimento em batelada, foram utilizados 5 reatores de controle (RC), 5 com fungos (RF) e 5 com fungos e glicose (RFG), verificando-se o uso de glicose (5 g. $\left.\mathrm{L}^{-1}\right)$, como substrato primário, e a remoção do fenol pelos fungos. Estes apresentaram maior desenvolvimento nos reatores contendo glicose (RFG), alcançando-se remoção de $100 \%$ de fenol, no quinto e último dia de experimento. Nestes reatores, a velocidade média de consumo de fenol foi quase o dobro da desenvolvida nos reatores sem glicose (RF). A redução de DQO foi superior nos reatores contendo glicose (RFG) com 93\%. Não houve remoção significativa de fenol nos reatores de controle. Nos RF, as maiores remoções de fenol e matéria orgânica foram registradas no quinto dia e foram, respectivamente, de $48 \%$ e $27 \%$. As maiores remoções de fenol em relação à de matéria orgânica indicam, possivelmente, a presença de compostos intermediários da degradação do fenol. Os reatores contínuos, cada um com volume total de 4,45 L e com meios suportes de manta de polipropileno (R1) e espuma de poliuretano (R2), foram mantidos sob as mesmas condições operacionais, durante 399 dias, divididos em três tempos de detenção hidráulica: 8 h, dividido em duas fases de alimentação (Fase I alimentação complementada com glicose e Fase II - alimentação sem complementação de glicose); 4 h e 6 h. As maiores remoções de fenol ocorreram durante o tempo de detenção hidráulica (TDH) de $8 \mathrm{~h}$, tanto com, quanto sem a presença de $0,5 \mathrm{~g} \cdot \mathrm{L}^{-1}$ de glicose no afluente, obtendo-se, na Fase I, remoções médias de fenol de 99,5\% $\pm 2(\mathrm{R} 1)$ e de $98 \% \pm 5(\mathrm{R} 2)$ e, na Fase II, 99,6\% \pm 1(R1) e $92 \% \pm 23$ (R2). No tempo de detenção hidráulica de 4 h, a remoção média de fenol ficou em torno de $50 \%$, em ambos os reatores. Com o tempo de detenção 
hidráulica de 6 h, houve melhora na eficiência de remoção, atingindo $72 \% \pm 35$ (R1) e $78 \% \pm$ 25 (R2). Análises microscópicas revelaram que os fungos cresceram bem nos suportes empregados, porém, o uso de espuma de poliuretano provocou maiores problemas operacionais. Apesar dos bons resultados de remoção de matéria orgânica e de fenol, houve crescimento excessivo de biomassa no interior dos reatores contínuos, o que resultou na colmatação do leito, indicando necessidade de se procurar melhor ajuste nutricional do meio para controlar a geração de biomassa.

O primeiro relato sobre o isolamento de microrganismos responsáveis pela degradação de fenol sob condições desnitrificantes foi apresentado por Bakker ${ }^{1}$ (1977), que obteve um crescimento mínimo da biomassa utilizando fenol como única fonte carbono.

Tschech e Fuchs (1987) obtiveram sucesso no isolamento de dois tipos de bactérias responsáveis pela degradação anaeróbia do fenol. Utilizando nitrato como aceptor final de elétrons, as Pseudomonas sp. K 172 e S 100, os autores observaram que havia aumento na velocidade de consumo do substrato com adição de bicarbonato. O processo foi inibido com a presença de oxigênio.

Van Schie e Young (1998) obtiveram cultura pura através do isolamento de microrganismos de sedimentos anaeróbios situados em três localidades geográficas distintas, utilizando fenol como fonte de carbono e energia sob condições desnitrificantes. Foram identificados três tipos de microrganismos sendo PH 002, CR 23 e FL 05, todos do gênero Azoarcus, já reconhecido anteriormente pela habilidade de fixar nitrogênio.

Shinoda et al. (2000) identificaram duas linhagens de microrganismos que degradavam fenol em condições desnitrificantes, Azoarcus sp dos tipos CC - 11 e CC - 26, que foram isoladas após enriquecimento de culturas incubadas por 1 e 3 anos, respectivamente. As duas linhagens necessitavam de íons de ferro para crescer, no entanto, o

\footnotetext{
${ }^{1}$ BAKKER, G. Anaerobic degradation of aromatic compounds in the presence of nitrate. FEMS Microbiology Letters, v. 1, p. 103 - 108, 1977.
} 
tipo CC - 26 cresceu melhor que o tipo CC - 11, sob limitadas concentrações de ferro. A linhagem CC - 26 cresceu com fenol, benzoato, além de outros compostos aromáticos. Análises filogênicas mostraram que essas linhagens eram semelhantes à Magnetospirillum sp., pertencentes a subclasse $\alpha$ da classe Proteobacteria, sendo esta a primeira linhagem envolvida na degradação de compostos aromáticos sob condições desnitrificantes integrante desse grupo.

\subsection{ACEPTORES DE ELÉTRONS}

Todos os organismos necessitam de energia para realizar reações de oxidação e redução. Nos microrganismos, os elétrons são removidos dos doadores de elétrons e transferidos para região intracelular. $\mathrm{O}$ transporte se divide em duas classes: livremente por difusão, através do citoplasma celular ou por ações enzimáticas onde são realizadas ligações com a membrana citoplasmática (RITTMANN; MCCARTY, 2001).

A transferência por difusão inclui as coenzimas nicotidamina-adenina dinucleotide (NAD+) e nicotidamina-adenina dinucleotide fosfato (NADP+). A coenzima NAD+ está relacionada com a geração de energia (catabolismo) e a NADP+ com as reações de biossíntese (anabolismo). As transferências feitas através de ligações com a membrana citoplasmática envolvem NADH dehidrogenase, flavoprotéinas, citocromos e quinonas (RITTMANN; MCCARTY, 2001).

Nos estudos de biodegradação, o cálculo do balanço de massa do consumo dos aceptores de elétrons, versus a biodegradação de compostos orgânicos, é uma importante ferramenta, pois pode dar idéia de como estes compostos estão sendo mineralizados, ou seja, 
se estão sendo utilizados para o crescimento da biomassa ou apenas transformados para metabólitos intermediários (BROHOLM et al., 2000).

Fermentação é um processo que não requer oxigênio ou a presença de qualquer outro aceptor de elétrons como $\mathrm{NO}_{3}^{-}, \mathrm{Mn}_{4}{ }^{+}, \mathrm{Fe}^{3+}, \mathrm{SO}_{4}{ }^{2-}$, ou $\mathrm{CO}_{2}$. Depende, principalmente, da capacidade do microrganismo usar parte da molécula orgânica como aceptor de elétrons. Durante a fermentação de um composto orgânico, há redução do nucleotídio piridina (NADH) e adenosina trifosfato (ATP) que é produzido na rota metabólica (a energia que é capturada em forma de ATP, é utilizada pela célula tanto para síntese como para manutenção celular) (REINEKE, 2001).

O metabolismo de compostos orgânicos através do mecanismo respiratório é mais eficiente do que conversões fermentativas. Durante o metabolismo oxidativo, o substrato orgânico é convertido em dióxido de carbono e parte dele é assimilada dentro do material celular. A oxidação de substratos orgânicos com oxigênio (usualmente, aceptor de elétrons predileto dos microrganismos) ou nitrato conduz a produções significativas de ATP (REINEKE, 2001).

Londry e Fedorak (1992) realizaram estudo sobre a formação de ácido benzóico a partir do fenol e de isômeros de cresol sob condições anaeróbias com diversos aceptores de elétrons. $\mathrm{O} p$ - cresol foi submetido à oxidação pelo grupo metil em culturas incubadas com os quatro aceptores listados na Tabela 3.3. O $m$ - cresol foi transformado através da para carboxilação com microrganismos redutores de sulfato e metanogênicos. $\mathrm{O} o$ - cresol foi submetido à oxidação pelo grupo metil por redutores de sulfato e pela para - carboxilação sob condições metanogênicas. Assim, os autores afirmaram que esses mecanismos indicam formação do ácido benzóico, através do fenol e do cresol, e que a presença deste ácido poderia facilitar a ativação da tioesterificação da CoA e posterior redução e clivagem do anel. 
Tabela 3.3 - Formação de ácidos benzóico através de fenol e isômeros de cresol.

\begin{tabular}{|c|c|c|c|c|}
\hline Aceptor de elétrons & Fenol & $p$-cresol & $m$-cresol & $o$-cresol \\
\hline $\mathrm{NO}_{3}^{-}$ & $\begin{array}{c}\text { para - } \\
\text { carboxilação }\end{array}$ & $\begin{array}{c}\text { oxidação grupo } \\
\text { metil }\end{array}$ & ND & ND \\
\hline $\mathrm{SO}_{4}{ }^{2-}$ & ND & $\begin{array}{c}\text { oxidação grupo } \\
\text { metil }\end{array}$ & $\begin{array}{c}\text { para - } \\
\text { carboxilação }\end{array}$ & $\begin{array}{c}\text { oxidação grupo } \\
\text { metil }\end{array}$ \\
\hline $\mathrm{CO}^{2}$ & $\begin{array}{c}\text { para - } \\
\text { carboxilação }\end{array}$ & $\begin{array}{c}\text { oxidação grupo } \\
\text { metil }\end{array}$ & $\begin{array}{c}\text { para - } \\
\text { carboxilação }\end{array}$ & $\begin{array}{c}\text { para - } \\
\text { carboxilação }\end{array}$ \\
\hline $\mathrm{Fe}_{3}^{+}$ & $\begin{array}{c}\text { para - } \\
\text { carboxilação }\end{array}$ & $\begin{array}{c}\text { oxidação grupo } \\
\text { metil }\end{array}$ & ND & ND \\
\hline
\end{tabular}

Fonte: (LONDRY; FEDORAK, 1992)

ND - Não Detectado

\subsection{DESNITRIFICAÇÃO}

Além dos esgotos domésticos, vários processos industriais contribuem com a produção de compostos nitrogenados tais como: produção de fertilizantes, manufaturação de explosivos, lavagem de gases industriais (onde, há absorção de NOx), recuperação de combustíveis nucleares (CHEN; LIN, 1993). As indústrias de laticínios, alimentícias, agricultura e farmacêutica, também são consideravelmente responsáveis pela produção desses compostos (FOGLAR; BRIŠKI, 2003).

Em águas residuárias, os compostos nitrogenados mais comumente encontrados são: nitrogênio orgânico ( $\mathrm{N}$ - orgânico), nitrogênio amoniacal (classificados em: íon amônio; $\mathrm{NH}_{4}{ }^{+}$ e gás amoníaco; $\left.\mathrm{NH}_{3}\right)$, nitrito $\left(\mathrm{N}-\mathrm{NO}_{2}\right)$, nitrato $\left(\mathrm{N}-\mathrm{NO}_{3}\right)$.

O lançamento de águas residuárias contendo nitrogênio pode causar sérios problemas ambientais, bem como, eutrofização, consumo de oxigênio e toxicidade para vida aquática, 
sobretudo, se o tratamento desses efluentes for incompleto ou precário (LUOSTARINEN et al., 2006).

A maioria dos processos biológicos que realiza a remoção de nitrogênio consiste basicamente em: amonificação (conversão do nitrogênio orgânico em amônia), nitrificação (amônia é oxidada a nitrato via nitrito) seguida de desnitrificação, na qual, nitrato é reduzido para nitrogênio molecular.

Os microrganismos envolvidos na nitrificação são quimiolitotróficos, pois fazem a oxidação da amônia para nitrato sob condições estritamente aeróbias. Este processo consiste em oxidações sucessivas, divididas em dois estágios; amônia para nitrito (oxidação da amônia) e nitrito para nitrato (oxidação do nitrito). As reações simplificadas podem ser vistas nas equações 3.1 e 3.2 , respectivamente.

Em cada etapa, estão envolvidos diferentes microrganismos que utilizam amônia ou nitrito com fonte de energia e oxigênio molecular como aceptor final de elétrons. Os que oxidam a amônia para nitrito são predominantemente membros do gênero Nitrosomonas. Contudo Nitrosococcus, Nitrosopira, Nitrosovibrio e Nitrolobus são igualmente capazes de realizar o processo. Estes organismos são geneticamente diversos, mas geralmente estão associados a subdivisão beta do grupo Proteobacteria.

Os organismos oxidadores do nitrito a nitrato pertencem principalmente ao gênero Nitrobacter. Entretanto outros gêneros como Nitrospira, Nitrospina, Nitroscoccus e Nirtrocystis, também são hábeis para realizar esta oxidação, estes microrganismos estão ligados à subdivisão alfa do grupo Proteobacteria.

$$
\begin{aligned}
& 2 \mathrm{NH}_{4}^{+}+3 \mathrm{O}_{2} \stackrel{\text { Nitrosomonas }}{\longrightarrow} 3 \mathrm{NO}_{2}^{-}+4 \mathrm{H}^{+}+2 \mathrm{H}_{2}+\text { energia } \\
& 2 \mathrm{NO}_{2}^{-}+\mathrm{O}_{2} \stackrel{\text { Nitrobacter }}{\longrightarrow} 2 \mathrm{NO}_{3}^{-}+\text {energia }
\end{aligned}
$$


Os microrganismos incorporam amônia durante o crescimento. No caso de águas residuárias com baixas concentrações de amônia ou nitrogênio orgânico, mas que contenham nitrato ou nitrito, é realizada a redução assimilativa desses compostos para amônia, a fim de que seja realizada a síntese celular. Por outro lado, o excesso de amônia pode causar efeitos deletérios nos corpos receptores, justificando assim, os limites de concentração estabelecidos pelas legislações ambientais (GRADY, Jr.; DAIGGER; LIM, 1999).

No Brasil, os padrões de lançamento estabelecidos pela CONAMA 357 (2005), limitam o valor máximo da concentração de nitrogênio amoniacal total em $20 \mathrm{mg} \cdot \mathrm{L}^{-1}$ - N, para lançamento de efluentes em corpos d'água. Para águas pertencentes a classe I (destinadas ao abastecimento para consumo humano e/ou à proteção das comunidades aquáticas), as concentrações de nitrato e nitrito, não podem exceder 10 e $1 \mathrm{mg} . \mathrm{L}^{-1}$ - N, respectivamente.

A contaminação dos corpos d'água com nitratos é um problema crônico. O nitrato é o principal precursor da metahemoglobina (cianose infantil) ou popularmente chamada de síndrome do bebê azul. A síndrome é causada pela redução do nitrato a nitrito, através de microrganismos situados no trato gastrintestinal infantil. $\mathrm{O}$ íon nitrito produzido oxida o Ferro II das moléculas de hemoglobina para Ferro III, que é incapaz de trocar oxigênio, podendo resultar em anoxia ou morte. A maioria dos casos de cianose infantil está relacionada com uso da água em concentrações superiores a $10 \mathrm{mg} \cdot \mathrm{L}^{-1}$. Com relação ao fato do nitrato ser ou não carcinogênico, há indicativos de que o consumo de altas concentrações de nitrato pode provocar câncer gástrico.

Altas concentrações de nitratos causam danos ao crescimento de culturas aquáticas que, por sua vez, implicam em prejuízos de cunho ambiental e comercial, pois comprovadamente, afetam espécies como as de polvo, camarão, enguia e trutas. Quanto aos benefícios da desnitrificação destacam-se: capacidade de tamponamento nos corpos 
receptores (há acréscimo de alcalinidade) e possível eliminação concomitante de diferentes fontes de carbono orgânico (RIJN; TAL; SCHREIER, 2006).

Em sistemas com recirculação, a nitrificação implica em consumo de alcalinidade (cerca de $7 \mathrm{mg} \mathrm{CaCO}_{3}$ para cada $\mathrm{mg}$ de $\mathrm{N}-\mathrm{NH}_{4}{ }^{+}$oxidada a nitrato). Condições ácidas impactam negativamente sistemas biológicos, e em função disso, rotineiramente há necessidade de suplementação de alcalinidade, sendo bastante utilizado bicarbonato de cálcio ou de sódio, para regularização do potencial hidrogeniônico $(\mathrm{pH})$ e de alcalinidade do sistema (RIJN; TAL; SCHREIER, 2006).

Embora microrganismos desnitrificantes não sejam essencialmente suscetíveis a oscilações dos valores do $\mathrm{pH}$, valores fora da faixa ótima (entre 7 e 8) podem acarretar em acúmulo de intermediários (nitrito, óxido nítrico e óxido nitroso). Em águas com baixos valores de alcalinidade, o pH pode ser estabilizado com o processo de desnitrificação, tendo em vista que há liberação de $\mathrm{OH}^{-}$no processo de remoção de nitrato. A equação 3.3 demonstra de forma simplificada, a geração da base supracitada, utilizando acetato, como fonte de carbono e energia (RITTMANN; MCCARTY, 2001).

$$
\mathrm{CH}_{3} \mathrm{COOH}+1,6 \mathrm{NO}_{3}^{-}+0,8 \mathrm{H}_{2} \mathrm{O} \rightarrow 0,8 \mathrm{~N}_{2}+2 \mathrm{H}_{2} \mathrm{CO}_{3}+1,6 \mathrm{OH}^{-}
$$

A equação 3.3 mostra que o incremento de 1,6 mol de $\mathrm{OH}^{-}$, corresponde a 1,6 mol de $\mathrm{N}-\mathrm{NO}_{3}$ reduzido. Em termos de massa, a alcalinidade é incrementada em $(50 / 14)=3,57 \mathrm{~g}$ $\mathrm{CaCO}_{3}$ por g. $\mathrm{N}-\mathrm{NO}_{3}$ consumido.

Akunna, Bizeau e Moletta (1993) realizaram testes em batelada, tendo sido avaliada a redução de nitrato e nitrito na presença de cinco tipos de fontes de carbono: glicose, glicerol, ácido acético, ácido lático e metanol. Houve acúmulo de amônia quando os substratos eram glicose e glicerol. Para todos os outros, houve desnitrificação com sucesso. Os autores 
constataram que houve $100 \%$ de remoção de nitrato e de nitrito, quando os doadores de elétrons eram ácidos lático e acético, cujas taxas de desnitrificação médias foram entre 23 e 27 g.N - NOx/g.SSV.h. Quanto ao metanol, os autores observaram pequena taxa de redução de N - NOx, indicando ausência (ou quantidade muito baixa) de microrganismos capazes de realizar desnitrificação.

Lee e Welander (1996) estudaram o efeito de quatro diferentes fontes de carbono sendo ácido acético, metanol, amido hidrolizado e um xarope contendo glicose, frutose e sacarose. O estudo foi realizado em batelada, com e sem adição de extrato de levedura. Os autores observaram que a desnitrificação poderia ser obtida com todas as fontes de carbono. $\mathrm{O}$ acetato proporcionou maior taxa de crescimento de Pseudomonas alcaligenes e o metanol a maior taxa de desnitrificação. O amido hidrolizado e o xarope proporcionaram maior produção de lodo, embora baixas taxas de desnitrificação em função de não haver apenas estímulo de microrganismos desnitrificantes, mas também de fermentativos e produtores de nitrito (Enterobacter asburiae, Klebsiella ozaenae). Quanto à influência da presença de extrato de levedura, não foi observada aumento significativo na desnitrificação, mas pode ter contribuído com baixo acúmulo de nitrito quando as fontes de carbono eram os carboidratos.

Karim e Gupta (2002) analisaram o efeito de diferentes fontes de carbono para biotransformação de nitrofenóis, na qual o nitrato foi empregado como aceptor de elétrons. O estudo foi realizado em escala de bancada em quatro reatores anaeróbios de manta de lodo UASB (R1, R2, R3 e R4), usando três fontes de carbono. O reator R1 foi usado como controle e os reatores R2, R3 e R4 foram alimentados com 30 mg.L ${ }^{-1}$ de 4 - nitrofenol (4 - NF) e 2,4 dinitrofenol (2,4 - DNF), respectivamente. Inicialmente, os reatores foram alimentados com acetato, seguidos de glicose e metanol. Quando comparado com acetato e glicose, o metanol teve melhor desempenho, como fonte de carbono para 4 - NF e 2,4 - DNF, ao passo que 2 NF não sofreu influência significativa com mudanças de substratos. O tempo de detenção 
hidráulica e a relação $\mathrm{DQO} / \mathrm{N}-\mathrm{NO}_{3}$ foi de 24 horas e 10, respectivamente. A remoção de $\mathrm{N}$ $\mathrm{NO}_{3}$ foi acima de $99 \%$, e a remoção de DQO para os reatores alimentados com nitrofenóis variou entre $85,7 \%$ e $97,7 \%$.

Gusmão (2005) avaliou o potencial de uma cultura pura desnitrificante, na biodegradação dos compostos de BTEX, através da operação de dois reatores anaeróbios de leito fixo preenchido com espumas de poliuretano. Células da cultura apresentaram coloração Gram negativa, com morfologia de cocos (diplococos e cocobacilos). A cultura foi capaz de crescer, sob condições desnitrificantes, utilizando diferentes substratos. A cultura não apresentou capacidade de crescer sob condições sulfetogênicas. Velocidades de crescimento ( $\mu$ ) de $0,046 \mathrm{~h}^{-1}$ e $0,050 \mathrm{~h}^{-1}$ e tempos de geração $(\mathrm{Tg})$ de 15,1 horas e 13,9 horas foram obtidos para as células crescidas em benzeno e etilbenzeno, respectivamente. Em todas as condições de alimentação às quais os reatores foram submetidos, houve remoção da matéria orgânica, nitrato e dos hidrocarbonetos. A menor eficiência de remoção de hidrocarbonetos foi de 89,4\%, obtida durante a alimentação dos reatores com benzeno. A matéria orgânica (DQO) foi removida com eficiência média de $87,1 \%$. A eficiência média de remoção de nitrato foi de 94\%. O sequenciamento das amostras revelou que o biofilme do RAHLF1 foi formado, principalmente, por espécies de Paracoccus, Pseudomonas e Bacteroides, enquanto que no RAHLF2, alimentado com etilbenzeno, observaram-se espécies dos gêneros: Paracoccus, Pseudomonas, Xanthomonas e Variovorax.

Iamamoto (2006) operou um reator em batelada seqüencial com biomassa em suspensão, que foi submetido a concentrações de N-amoniacal de 125, 250 e $500 \mathrm{mg}$ N/L, com concentração de oxigênio dissolvido (OD) no reator de $2 \mathrm{mg} \mathrm{O} \cdot \mathrm{L}^{-1}$, em ciclos de $2 \mathrm{~h} / 2 \mathrm{~h}$ de anóxico/aeróbio. Em todas as fases, o reator foi operado em batelada alimentada. $\mathrm{Na}$ condição de $125 \mathrm{mg} \mathrm{N} . \mathrm{L}^{-1}$, obteve-se eficiência de remoção de $87 \%$ de N, sendo o nitrato o principal produto da nitrificação. $\mathrm{Na}$ condição de $250 \mathrm{mg} \mathrm{NL}^{-1}$, obteve-se eficiência de 
remoção de $\mathrm{N}$ de $84 \%$, com predominância de nitrito como principal produto da nitrificação e com ocorrência de nitrificação e desnitrificação simultânea durante os dois primeiros ciclos aeróbios. Na condição de $500 \mathrm{mg} \mathrm{N} . \mathrm{L}^{-1}$, as condições de concentração de OD de $2 \mathrm{mg} \mathrm{O} \mathrm{L}^{-1}$ e aeração intermitente a cada $2 \mathrm{~h}$ não foram suficientes para promover a remoção total de nitrogênio amoniacal. Foram feitas alterações: ciclos de $2 \mathrm{~h}$ anóxico e $9 \mathrm{~h}$ aeróbios, com concentração média de $2,8 \mathrm{mg} \mathrm{O}_{2} \mathrm{~L}^{-1}$, que resultaram em eficiências de remoção de $\mathrm{N}$ de 94\%, com predominância de nitrito. Foram isoladas cepas desnitrificantes com similaridade de 97\% para Thauera mechernichensis e Thauera sp. 27 nas condições operacionais de 125 e $250 \mathrm{mgN} \mathrm{L}^{-1}$ e de $99 \%$ para Ochrobactrum anthropi e Ochrobactrum tritici, na condição operacional de $500 \mathrm{mgN} \mathrm{L}^{-1}$. O longo tempo de operação resultou na diminuição da população de bactérias oxidantes de nitrito, podendo ter sido uma das causas que contribuiu para que se criassem condições que levariam à nitrificação via nitrito na concentração de $500 \mathrm{mg} \mathrm{N} \mathrm{L}{ }^{-1}$. O sucesso na prevenção da inibição do processo por amônia livre foi atribuído à adoção das condições operacionais do reator, que foi operado sob aeração intermitente e batelada alimentada.

Lakshimi e Setty (2007) avaliaram a transferência de massa entre líquido - sólido do processo de desnitrificação em um reator anóxico de leito fluidificado, que teve a biomassa imobilizada em esferas de plástico. Os autores avaliaram a taxa de desnitrificação sob diferentes condições operacionais. Os resultados dos experimentos foram utilizados para simular um modelo para avaliar o coeficiente de transferência de massa usando os valores das concentrações de biomassa na superfície do biofilme. Os autores concluíram que o aumento da taxa de recirculação fazia com que a taxa de transferência de massa diminuísse independentemente da concentração inicial de nitrogênio e que até uma determinada taxa de carregamento de nitrogênio, houve acréscimo na espessura do biofilme, mas que após ultrapassar essa taxa de carregamento a espessura diminuiu continuamente. 


\subsection{REMOÇÃO DE FENOL SOB CONDIÇÕES DESNITRIFICANTES}

As características da fonte de carbono têm influência significativa no processo de desnitrificação, sobretudo, quanto aos principais parâmetros do processo, como: taxa de desnitrificação, atividade desnitrificante, produção de lodo e composição da microflora (LEE; WELANDER, 1996).

Durante a biodegradação, algumas fontes de carbono são oxidadas para dióxido de carbono; no processo, há liberação de elétrons para redução ou formação de hidrogênio. Sob condições estritamente anaeróbias, a metanogênese utiliza os elétrons e as moléculas de hidrogênio liberadas para formação de metano. Na presença de nitrato, microrganismos desnitrificantes o reduzem para $\mathrm{N}_{2}$, podendo usar vários tipos de substratos, a fim de serem supridos de elétrons e de hidrogênio. Assim, microrganismos desnitrificantes competem com metanogênicos por acetato e hidrogênio, como ilustrado na Figura 3.4 (FANG; ZHOU, 1999).

Fang e Zhou (1999) realizaram estudo com intuito de verificar interação entre desnitrificação e a metanogênese, utilizando fenol (100 mg. $\left.\mathrm{L}^{-1}\right)$ e $m$ - cresol (200 mg. $\left.\mathrm{L}^{-1}\right)$ como substratos e nitrato como aceptor de elétrons, variando suas concentrações. O experimento foi realizado em reator UASB. A metanogênese ocorreu apenas quando a relação DQO/N - $\mathrm{NO}_{3}$ foi maior que 3,34. Quando a relação foi 5,23, cerca de $98 \%$ de fenol foi removido, mas apenas $60 \%$ de $m$ - cresol foi degradado. Através dos dados observados, os autores puderam concluir que a atividade metanogênica é afetada pela presença de nitrato, de maneira que quanto maior a concentração de $\mathrm{N}^{-\mathrm{NO}_{3}}{ }^{-}$, menor foi a produção de metano. 


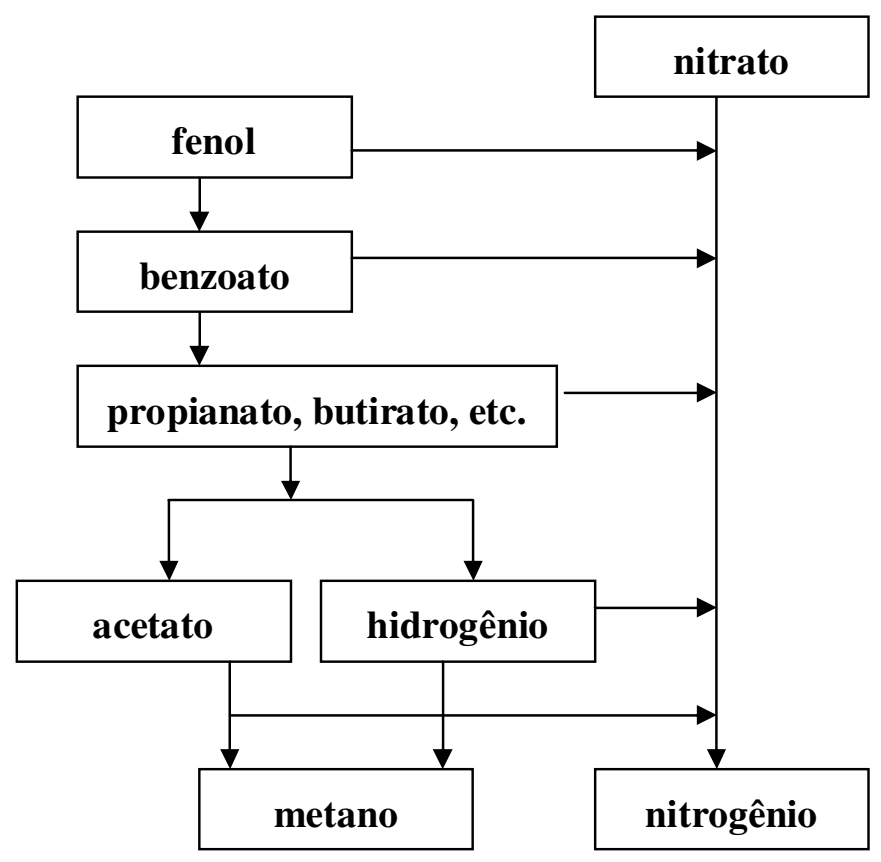

Figura 3.4 - Interação entre metanogênese e desnitrificação na degradação do fenol.

Aun (2001) avaliou uma unidade piloto de lodos ativados que realizava nitrificação (tanque de aeração) e desnitrificação (reator anóxico), em que havia alimentação contínua com água residuária sintética semelhante as que são produzidas em indústrias de coque. A água residuária continha, basicamente, fenol (1000 mg. $\left.\mathrm{L}^{-1}\right)$ como principal fonte de carbono, cloreto de amônio (750 N.L $\mathrm{L}^{-1}$ ), além de hidrocarbonetos aromáticos e alguns micronutrientes inorgânicos, ambos em concentrações bem menores. O nitrogênio amoniacal presente no sistema era nitrificado no tanque de aeração e o nitrato formado era lançado no reator anóxico com auxílio do lodo retornado do decantador secundário.

O objetivo do trabalho foi obtenção da taxa de desnitrificação da unidade, a partir de um reator anóxico, alimentado com a mesma água residuária que foi empregada na estação piloto. A pesquisa foi dividida em três fases, as duas primeiras com emprego de lodo aeróbio e a última, com lodo dos reatores anóxicos, ambos originados na unidade piloto. A primeira fase foi a avaliação dos efeitos do fenol sobre a biomassa; a segunda teve como objetivo a avaliação da taxa de decaimento do nitrato no sistema e a determinação do valor ótimo da 
relação Alimento/Microrganismo (A/M). A terceira fase foi a reprodução do sistema piloto com mais fidelidade, a partir dos testes realizados na segunda fase.

A conclusão do trabalho foi que relações A/M maiores que $0,10 \mathrm{~kg}$.fenol. $\mathrm{kg}^{-1} \cdot \mathrm{SSV}^{-1}$. $\operatorname{dia}^{-1}$ não eram adequadas, pois o sistema apresentava instabilidade, inclusive acúmulo de fenol. O sistema apresentou estabilidade com utilização de lodos anóxicos, cujas taxas de decaimento de nitrato eram de 0,4 a $0,6 \mathrm{~kg} \mathrm{~N}-\mathrm{NO}_{3} \cdot \mathrm{kg}^{-1} \cdot \mathrm{SSV}^{-1} \cdot \mathrm{dia}^{-1}$. Com utilização dos lodos aeróbios, houve acúmulo de nitrato nos efluentes (300 mg N $\left.-\mathrm{NO}_{3} \mathrm{~L}^{-1}\right)$ e o reator também apresentava acúmulo de nitrito (até $50 \mathrm{mg} \mathrm{N}-\mathrm{NO}_{2} \mathrm{~L}^{-1}$ ) afetando substancialmente a desnitrificação. As faixas ótimas de concentração de nitrato para desnitrificação estavam situadas entre 10 e $80 \mathrm{mg} \mathrm{N}-\mathrm{NO}_{3} \mathrm{~L}^{-1}$.

Dombroski (2003) realizou um trabalho semelhante ao apresentado por Aun (2001), simulando água residuária de coqueria em sistemas de lodos ativados de lodo único. Durante a partida do sistema, ainda em processo de adaptação da biomassa visando nitrificação, foram empregadas relações $\mathrm{A} / \mathrm{M}$ em torno de $0,010 \mathrm{~kg} \cdot \mathrm{N}-\mathrm{NH}_{3} \cdot \mathrm{kg} \cdot \mathrm{SSV}^{-1}{ }_{\text {aeróbio.d }}{ }^{-1}$. Não houve acúmulo de fenol para concentrações médias de nitrato afluente em torno de $15 \mathrm{mg} . \mathrm{N}_{-} \mathrm{NO}_{3} . \mathrm{L}^{-}$ ${ }^{1}$. Ao longo da operação contínua do sistema, o reator apresentou desempenho estável com relação a eficiência de remoção de fenol e de DQO (96,1 a 99,6 \% e 76,0 a 87,7\%, respectivamente).

Vale salientar que a autora operou o reator com fração anóxica de 0,4 do volume total do reator, TDH entre 0,8 e 1,1 dias. Foram testadas várias idades do lodo, de maneira que estas variaram entre 29 e 60 dias. Para estas condições extremas, o sistema apresentou eficiência de remoção entre 40,3 e 58,7\% de nitrogênio; 99,9\% de fenol; 92,4 a 96,0\% de DQO e valores superiores a 99,1\% de nitrogênio amoniacal. Observou-se uma relação $\mathrm{DQO}_{\text {removida }} / \mathrm{N}-\mathrm{NO}_{3}$ removido $=4,20 \pm 0,12$, enquanto para a relação $\mathrm{DQO}_{\text {afluente }} / \mathrm{N}-\mathrm{NO}_{3 \text { afluente }}=$ 
$3,26 \pm 0,07$, o que demonstrou que a remoção de nitrogênio foi limitada pela disponibilidade de fonte de carbono na água residuária bruta.

Sarfaraz et al. (2004) conduziram estudos para avaliar a remoção de fenol em condições anóxicas, em Reator de Batelada Seqüencial (SBR), com diferentes ciclos de operação e concentrações de fenol. Os resultados apresentados mostram que, quando as concentrações afluentes de fenol foram em torno de $1050 \mathrm{mg} \cdot \mathrm{L}^{-1}$, a eficiência na remoção de fenol foi superior a $80 \%$, com ciclos de operação correspondente a 6 horas, o que implica em taxa de carregamento equivalente a 6,4 $\mathrm{kg}$. DQO. $\mathrm{m}^{-3} \cdot \mathrm{d}^{-1}$. Em média, $1 \mathrm{~g}$ de nitrato consumiu 3,4 g de DQO (contabilizando apenas a contribuição do fenol removido). A fração de DQO que contribuiu efetivamente para crescimento celular foi em torno de $11 \%$.

Eiroa et al. (2005) avaliaram a biodegradação do fenol e do formaldeído durante o processo de desnitrificação. Os estudos foram conduzidos em batelada e em reator contínuo anóxico, ambos em escala de bancada. Testes em batelada investigaram a biodegradação do formaldeído como fonte única de carbono $\left(260 \mathrm{mg} . \mathrm{L}^{-1}\right)$ e com a presença do fenol, com concentrações variando entre 30 a $180 \mathrm{mg} \cdot \mathrm{L}^{-1}$. A taxa de biodegradação inicial foi de $0,5 \mathrm{~g}$ $\mathrm{CH}_{2} \mathrm{O} \mathrm{g} \mathrm{SSV}^{-1}$. $\mathrm{d}^{-1}$. Quanto ao fenol, a biodegradação foi observada com concentrações entre 30 e $180 \mathrm{mg} \cdot \mathrm{L}^{-1}$. O processo de desnitrificação foi inibido com concentrações de fenol acima de $360 \mathrm{mg} \cdot \mathrm{L}^{-1}$. Estudos foram igualmente conduzidos em reator UASB, com eficiência de remoção de formaldeído em torno de $99,5 \%$, para todas as taxas de carregamento aplicadas que foram na faixa de 0,89 a $0,14 \mathrm{~g}$ DQO $\left(\mathrm{CH}_{2} \mathrm{O}\right) \cdot \mathrm{L}^{-1} \mathrm{~d}^{-1}$. A taxa de carregamento de fenol aumentou de 0,3 para 1,3 g DQO $\left(\mathrm{C}_{6} \mathrm{H}_{6} \mathrm{O}\right) \cdot \mathrm{L}^{-1} \mathrm{~d}^{-1}$. As eficiências de remoção de fenol foram cerca de 90,6 \%, com concentrações de fenol afluente entre 27 e 755 mg. $\mathrm{L}^{-1}$. A eficiência diminuiu quando a concentração afluente de fenol aumentou para $1010 \mathrm{mg} \cdot \mathrm{L}^{-1}$. As porcentagens de desnitrificação foram em torno de $98,4 \%$ para concentrações afluentes de até 
$755 \mathrm{mg} . \mathrm{L}^{-1}$. Após o incremento da concentração de fenol para $1010 \mathrm{mg} . \mathrm{L}^{-1}$, a remoção de nitrogênio decresceu, em função do efeito inibitório do fenol.

Zhu et al. (2006), após realizarem enriquecimento gradual de cultura anaeróbia por 110 dias, fizeram a transferência do meio adaptado para um reator UASB, com temperatura mantida a $25^{\circ} \mathrm{C}$, cujas concentrações de fenol e de $\mathrm{N}-\mathrm{NO}_{3}$ variaram até $600 \mathrm{mg} \cdot \mathrm{L}^{-1}$ e 430 mg. $\mathrm{L}^{-1}$, respectivamente. Após o fim do enriquecimento (dia 110), 93,3\% do fenol e $98 \% \mathrm{~N}$ $\mathrm{NO}_{3}{ }^{-}$foram removidos, com Tempo de Detenção Hidráulica (TDH) de 20,25 horas. A remoção de $1 \mathrm{~g}$ de $\mathrm{N}-\mathrm{NO}_{3}$ necessitou de cerca de 3,19 g de DQO. Testes em batelada mostraram que a presença de cresol, nitrofenol e monoclorinado de fenol (MCP) causou efeitos prejudiciais à cultura enriquecida, inibindo sua capacidade de tratamento.

Os autores dividiram a operação do sistema em 6 fases. Na transição da terceira para quarta fase, a concentração de fenol aplicada foi de $400 \mathrm{mg} \cdot \mathrm{L}^{-1}$, o TDH foi diminuído implicando em um acréscimo na taxa de carregamento. A taxa de carregamento de fenol aumentou de $0,15 \mathrm{~kg}$.fenol. $\mathrm{m}^{-3} \cdot \mathrm{dia}^{-1}$ para $0,25 \mathrm{~kg} \cdot$ fenol.m $\mathrm{m}^{-3} \cdot \mathrm{dia}^{-1}$ (relação DQO/ N-NO 3 igual a 3,31), o fenol acumulou rapidamente, de maneira que a concentração no efluente passou de 28,6 mg. $\mathrm{L}^{-1}$ para $351,2 \mathrm{mg} . \mathrm{L}^{-1}$ (queda de eficiência de $92 \%$ para $17,5 \%$ ), e o N-NO 3 de 24,5 mg.L $\mathrm{L}^{-1}$ para 330,9 mg.L $\mathrm{L}^{-1}$ (eficiência de $92 \%$ para zero).

Queiroz (2006) estudou a remoção biológica do nitrogênio pela via simplificada (nitritação), utilizando fenol como fonte de carbono na etapa anóxica (desnitrificação) em um sistema de lodos ativados com biomassa em suspensão. Para tanto, operou reator piloto (volume útil de 20 litros) em bateladas sequienciais alimentado com 5 (cinco) litros de água residuária sintética. A investigação foi caracterizada pela utilização do fenol $(1.000 \mathrm{mg}$ $\mathrm{C}_{6} \mathrm{H}_{5} \mathrm{OH} . \mathrm{L}^{-1}$ ) e pelo aumento gradual da concentração de nitrogênio amoniacal no despejo líquido sintético (200; 300 e $500 \mathrm{mg} \mathrm{N} / \mathrm{L})$, buscando as condições que permitissem a predominância do $\mathrm{N}-\mathrm{NO}_{2}$, ao final da fase aeróbia dos ciclos de tratamento e utilização do 
fenol pelos microrganismos heterotróficos para redução do nitrogênio oxidado durante a fase anóxica. Para a presente pesquisa, as condições para predominância do $\mathrm{N}-\mathrm{NO}_{2}$ na massa líquida do reator ao final da etapa aeróbia foram: $\mathrm{pH}=8,3$ associado à extensão do período aeróbio do ciclo de tratamento que garantisse concentração mínima de amônia livre (> 0,3 mg $\left.\mathrm{NH}_{3} \mathrm{~L}^{-1}\right)$ no reator. Com estas condições, a relação $\mathrm{N}-\mathrm{NO}_{2} /\left(\mathrm{N}-\mathrm{NO}_{2}+\mathrm{N}-\mathrm{NO}_{3}\right)$ variou entre 89 e $99 \%$. Mantendo uma concentração de $1,0 \mathrm{mg} \mathrm{O}_{2} \mathrm{~L}^{-1}$ no reator durante a fase aeróbia e tempo de detenção hidráulica de três dias, as eficiências de remoção de $\mathrm{N}-\mathrm{NH}_{3}$ variaram entre: 89 e 98\%, com concentrações no afluente próximas a $200 \mathrm{mg} \mathrm{N} / \mathrm{L}$ (nove ciclos de tratamento); 95 e 98\%, para concentrações no afluente da ordem de $300 \mathrm{mg}$ N/L (cinco ciclos de remoção) e 95 e $97 \%$, com concentrações no afluente próximas a $500 \mathrm{mg} \mathrm{N} / \mathrm{L}$ (três ciclos de tratamento). Durante o experimento as temperaturas estiveram entre 23,5 e $33^{\circ} \mathrm{C}$ e as concentrações de

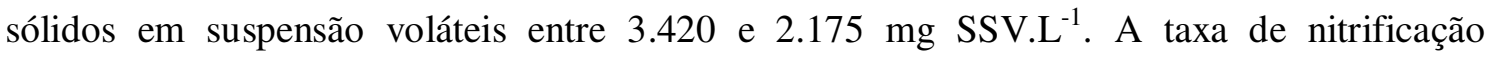
específica variou entre 0,01 e $0,05 \mathrm{~kg} \mathrm{~N}-\mathrm{NH}_{3} / \mathrm{kg}$ SSV. dia. Concentrações máximas de

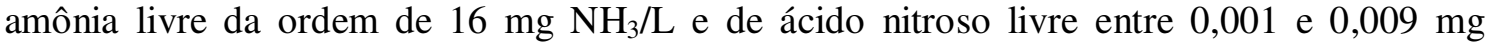
$\mathrm{HNO}_{2} \mathrm{~L}^{-1}$ inibiram a oxidação biológica do nitrogênio. Fenol, em concentrações no afluente próximas a $1.000 \mathrm{mg} . \mathrm{L}^{-1}$, mostrou-se adequado como única fonte de carbono para remoção de nitrogênio, via nitrito, para concentrações afluentes da ordem de 200 e 300 mg N/L. As eficiências de remoção do nitrogênio oxidado variaram entre 97 e 100\%, utilizando taxas de aplicação volumétricas próximas a $0,03 \mathrm{~kg}$ fenol $/ \mathrm{m}_{3}$.hora. As taxas de desnitrificação específicas variaram entre 0,01 e $0,05 \quad \mathrm{~kg} \quad \mathrm{~N}-\mathrm{NO}_{2} \cdot \mathrm{kg}^{-1} \mathrm{SSV}^{-1} \cdot \mathrm{dia}^{-1} ;$ a relação alimento/microrganismo (A/M) esteve compreendida entre 0,06 e $0,13 \mathrm{~kg}^{-1}$.fenol.SSV ${ }^{-1} \cdot \mathrm{dia}^{-1}$, a relação fenol ${ }_{\text {removido }}$ por $\mathrm{N}$ - $\mathrm{NOx}_{\text {removido }}$ variou entre 2,1 e 3,2 g.fenol removido $_{\text {por }} \mathrm{g} \mathrm{N}-\mathrm{NOx}$ removido e as eficiências de remoção do fenol, durante a etapa anóxica, estiveram compreendidas entre 37 e 67\%. Taxas de aplicação volumétricas da ordem de 0,07 kg.fenol. $\mathrm{m}^{-3}$.hora ${ }^{-1}$ inibiram a desnitrificação biológica. Os três ciclos de tratamento da etapa 
conduzida com concentração de $500 \mathrm{mg} \mathrm{N} . \mathrm{L}^{-1}$ no afluente foram marcados pela inibição da desnitrificação e acúmulo de fenol, causados pelas elevadas concentrações de $\mathrm{N}-\mathrm{NO}_{2}(80$ a 98

mg N $-\mathrm{NO}_{2} \mathrm{~L}^{-1}$ ) na massa líquida do reator. Ainda durante essa etapa, a coleta de amostra na fase anóxica dos ciclos de remoção para realização de ensaios exploratórios, associando cromatografia gasosa e espectrometria de massa, detectaram a formação de 2 e 4 - nitrofenol no conteúdo do reator piloto.

\subsection{RELAÇÃO C/N}

Sob condições ótimas de operação, o processo biológico de desnitrificação, em meio anóxico, converte mais de $95 \%$ de nitrato em nitrito e este em gás nitrogênio. Quando as condições ambientais não são favoráveis, o processo pode ser incompleto, ou seja, a desnitrificação pode gerar produtos intermediários indesejáveis $\left(\mathrm{N}-\mathrm{NO}_{2}, \mathrm{~N}_{2} \mathrm{O}\right)(\mathrm{CHIU}$; CHUNG, 2003).

Diversos fatores podem afetar o processo, tais como: idade do lodo, TDH, carregamento orgânico, tipos de fontes de carbono, oxigênio dissolvido (OD), pH, e temperatura. Dentre todos estes parâmetros, o que mais contribui com a formação de $\mathrm{N}_{2} \mathrm{O}$ é a relação entre carbono e nitrogênio (CHIU; CHUNG, 2003).

Usualmente, no processo de desnitrificação, altas concentrações de carbono no afluente são favoráveis para conversão de nitrato ou nitrito em gás nitrogênio. Entretanto, elevadas concentrações de carbono podem também ser um aspecto negativo, pois se houver muito mais carbono do que os microrganismos necessitam para realizar a desnitrificação, este excesso de carbono poderá não ser consumido pelos microrganismos que podem vir a ser 
descartados no efluente, que implica no aumento das concentrações de DQO na saída do sistema, fato que é sempre indesejável (CHIU; CHUNG, 2003).

Teoricamente, a redução de $1 \mathrm{~g}$ de $\mathrm{N}-\mathrm{NO}_{3}$ para $\mathrm{N}_{2}$ requer 2,86 $\mathrm{g}$ de DQO; no entanto, os estudos mostram que, na maioria das vezes, este valor é maior em função do requerimento de carbono orgânico extra para crescimento celular (ZHU et al., 2006). O coeficiente 2,86 vem das equações 3.4 e 3.5;

$$
\begin{aligned}
& \mathrm{O}_{2}+4 \mathrm{H}^{+}+4 e^{-} \rightarrow 2 \mathrm{H}_{2} \mathrm{O} \\
& \mathrm{NO}_{3}^{-}+6 \mathrm{H}^{+}+5 e^{-} \rightarrow 0,5 \mathrm{~N}_{2}+3 \mathrm{H}_{2} \mathrm{O}
\end{aligned}
$$

As equações 3.4 e 3.5 mostram que: $(32 / 4) /(14 / 5)=2,86 \mathrm{mg} \mathrm{O}_{2}$ por $\mathrm{mg}$ de $\mathrm{N}-\mathrm{NO}_{3}$. Diversas relações entre carbono e nitrogênio têm sido reportadas com valores situados entre 3,4 a 5,3 (CHEN; LIN, 1993; FANG; ZHOU, 1999; SARFARAZ et al., 2006).

Este valor se refere a desnitrificação completa, ou seja, quando o produto final é nitrogênio gasoso. Caso haja liberação de produtos intermediários como $\left(\mathrm{N}_{2} \mathrm{O}^{-}, \mathrm{NO}, \mathrm{N}_{2} \mathrm{O}\right)$, o valor da relação diminui.

Embora a maneira mais usual de apresentar a relação entre carbono e nitrogênio seja em termos de DQO, alguns autores preferem referenciar apenas o carbono relacionado à fonte principal do mesmo, em virtude de algumas composições de águas residuárias conterem outras fontes de carbono que, de maneira geral, são facilmente biodegradáveis e/ou se apresentam em pequenas concentrações.

Her e Huang (1995) realizaram testes em batelada com quatro fontes de carbono (metanol, ácido acético, glicose e ácido benzóico), com objetivo de avaliar o efeito das diferentes relações $\mathrm{C} / \mathrm{N}$ sobre a eficiência de desnitrificação e sobre as relações entre 
metanogênese e desnitrificação. Os autores observaram que, para valores semelhantes de $\mathrm{C} / \mathrm{N}$, a eficiência da desnitrificação foi significativamente menor para o ácido benzóico, quando comparado às outras três fontes de carbono não-aromáticas, ou melhor; o valor mínimo de $\mathrm{C} / \mathrm{N}$ para desnitrificação completa foi maior para o composto aromático do que para as demais fontes de carbono.

A relação mínima de $\mathrm{C} / \mathrm{N}$ aumentou conforme o acréscimo do peso molecular das fontes de carbono, sugerindo assim que, além da interferência da estrutura química, a massa molecular está correlacionada com a eficiência de desnitrificação. A atividade desnitrificante do lodo poderá ser inibida completamente se a concentração de ácido benzóico ultrapassar 1090 mg.L $\mathrm{L}^{-1}$, mesmo quando operado com relações de C/N comprovadamente eficazes.

Santos (2003) avaliou comparativamente o desempenho de reatores desnitrificantes em batelada, usando etanol, metanol e gás metano como doadores de elétrons. Foram testadas diferentes relações carbono - nitrogênio para o etanol e o metanol, cujos valores testados foram 1,0, 0,75 e 0,5. A melhor razão testada foi a correspondente a 1. Houve desnitrificação completa pra todas as fontes de carbono empregadas, contudo, o etanol se mostrou como o composto mais eficiente para o processo. Quanto ao metano, a desnitrificação foi realizada na presença e na ausência de oxigênio. Ambas tentativas tiveram êxito, embora as velocidades das reações foram mais baixas quando comparadas aos outros compostos testados Além destes testes, foram realizados ensaios de purificação, com lodo dos reatores anóxicos alimentados com metano, a fim de se obterem culturas puras, tanto de microrganismos desnitrificantes utilizadores de metano, como de consórcios bacterianos compostos por organismos metanotróficos e desnitrificantes. Os resultados destes ensaios mostraram predomínio de bacilos com coloração gram-negativa.

Ruiz, Jeison e Chamy (2006) avaliaram o desempenho de 5 reatores UASB, inoculados com grânulos metanogênicos, tendo empregado acetato de sódio como fonte de 
carbono. No estudo, foram realizados vários testes com diferentes relações $\mathrm{DQO} / \mathrm{N}-\mathrm{NO}_{3}$, a fim de avaliar a atividade metanogênica e desnitrificante do lodo.

Os autores concluíram que a relação entre carbono e nitrogênio influencia significativamente a atividade da biomassa. Para valores de $\mathrm{DQO} / \mathrm{N}-\mathrm{NO}_{3}$ menores que 5 , a estrutura granular do lodo não foi preservada, dando lugar a um lodo floculento, com baixa velocidade de sedimentação, o qual dificultou a operação dos reatores, tendo em vista a recorrente necessidade de limpeza.

\subsection{REATORES DE LEITO FLUIDIFICADO}

Nas últimas décadas, diversos estudos têm sido realizados sobre as mais variadas possibilidades de configurações de reatores bioquímicos, que se utilizam de processos anaeróbios, não só contribuindo com aperfeiçoamento de técnicas clássicas, como também no desenvolvimento de novas concepções de reatores (GAVRILESCU, 2002).

Sensibilidade e baixa taxa de crescimento dos microrganismos anaeróbios podem ser consideradas importantes fatores de risco em sistemas anaeróbios. O emprego de reatores de alta-taxa, ao invés de sistemas convencionais, tem sido amplamente utilizado, pois de maneira geral, possuem menores TDH e maiores tempos de retenção celular (TRC) (GAVRILESCU, 2002).

Diversas configurações de reatores anaeróbios de alta taxa vêm sendo desenvolvidas para tratamento de águas residuárias. Dentre essas, o reator anaeróbio de leito fluidificado tem sido considerado como um avanço tecnológico (SEN; DEMIRER, 2003). Reatores tipo RALF têm sido empregado com sucesso no tratamento de águas residuárias com diferentes 
composições, inclusive em efluentes dificilmente biodegradáveis (GEORGIO; AIVASIDIS, 2006; MOTELEB et al., 2002).

Reatores de leito fluidificado apresentam uma série de vantagens no tratamento de água residuárias, quando comparados com outros tipos de processos biológicos (BLANCO; ENCINA; POLANCO, 1995). A Tabela a seguir mostra as faixas de variação de alguns parâmetros de operação do RALF comparadas a sistemas anaeróbios tradicionais.

Tabela 3.4 - Faixas de variação de parâmetros operacionais de alguns reatores anaeróbios

\begin{tabular}{ccccc}
\hline Processo & $\begin{array}{c}\text { DQO } \\
\text { afluente }\left(\mathrm{mg}^{-1} \mathrm{~L}^{-1}\right)\end{array}$ & $\begin{array}{c}\text { TDH } \\
(\mathrm{h})\end{array}$ & TCO (kg.DQO.m $\left.{ }^{-3} \cdot \mathrm{dia}^{-1}\right)$ & $\begin{array}{c}\text { DQO } \\
\text { removida (\%) }\end{array}$ \\
\hline Contato anaeróbio & $1500-5000$ & $2-10$ & $0,480-2403$ & $75-90$ \\
UASB & $5000-15000$ & $4-12$ & $4005-12014$ & $75-85$ \\
Leito fixo & $10000-20000$ & $24-28$ & $0,961-4,806$ & $75-85$ \\
Leito fluidificado & $5000-10000$ & $5-10$ & $4,806-9,611$ & $80-85$ \\
\hline
\end{tabular}

Fonte: (GAVRILESCU, 2002).

O RALF consiste em um recipiente cilíndrico preenchido com meio suporte inerte que é fluidificado através das taxas de alimentação e/ou recirculação. O separador trifásico localizado no topo do reator permite separação de líquido, biogás e sólidos. Quando o biofilme adere ao meio suporte, a densidade da partícula decresce (facilitando sua ascensão). Simultaneamente, a turbulência gerada pela fluidificação provoca o desprendimento do biofilme, a recirculação permite o retorno de parte dessa biomassa livre para o sistema, podendo ser aderida novamente ao meio suporte. Assim a densidade do meio é controlada e a homogeneidade garantida (HOLST; TRUC; PUJOL, 1997).

O reator de leito fluidificado tem recebido considerável atenção para o tratamento de águas residuárias. Quando comparado com sistemas que possuem retenção de biomassa, esses 
reatores possuem várias vantagens, como alta concentração de biomassa, idade de lodo mais elevada, baixos valores de TDH, altas taxas de remoção volumétrica e relativamente requer menores áreas.

A biomassa adere e cresce no meio suporte inerte, formando um biofilme, onde é consumido o substrato que está no reator. Muitos materiais têm sido utilizados com sucesso como meio suporte para imobilização da biomassa, como areia, basalto e carvão ativado. Quando a densidade do suporte é alta como areia e basalto, se faz necessário utilizar partículas com diâmetros menores para se estabelecer uma adequada fluidificação. As características do suporte (porosidade, rugosidade e carga elétrica) são muito importantes para os primeiros estágios da formação do biofilme (em muitas situações o meio suporte é testado fora do reator, antes de ser dado início a operação contínua do sistema) (ALVES; MELO; VIEIRA, 2002).

Durante a operação contínua do reator, o desempenho e a estabilidade dependem da estrutura formada do biofilme em torno do suporte. Além dos parâmetros já mencionados, a natureza e a concentração do substrato podem afetar o crescimento e a composição da biomassa. Sob altas taxas de carregamento orgânico (TCO), a acumulação do biofilme é alta, afetando assim, a estrutura formada (ALVES; MELO; VIEIRA, 2002).

Os biofilmes são sistemas heterogêneos, nos quais os microrganismos são envolvidos em uma matriz de substâncias poliméricas extracelulares, parecidas com gel, sendo $98 \%$ da massa devido, principalmente, à água e sais. A elevada produção de polímeros extracelulares insolúveis pode causar a colmatação dos leitos, ou então problemas com a floculação do lodo, impedindo desta forma, que os sistemas atinjam a eficiência necessária para o tratamento (MIQUELETO, 2006).

Margaritis e Pace (1986) afirmam que a quantidade de substrato convertida pelas células em polímero depende da composição do meio de crescimento. Geralmente, meios 
contendo razões elevadas de $\mathrm{C} / \mathrm{N}$ favorecem a produção de exopolisacarídeos. Mengistu et al. (1994) relatam que o déficit de um nutriente essencial, como o nitrogênio, por exemplo, pode limitar o crescimento celular ao passo que a energia proveniente do excesso de carbono é usada para a biossíntese de polissacarídeos.

Hidalgo e Encina (2002) avaliaram o crescimento do biofilme em um RALF, sob condições mesofílicas, empregando biólito como meio suporte e ácido acético como fonte única de carbono. A expansão do leito foi mantida em torno de $40 \%$. Observou-se que a diminuição da expansão provocou um aumento de biomassa no reator; no entanto, houve diminuição da taxa da remoção da matéria orgânica. Isto pode ser explicado por um fenômeno de limitação de transferência de massa.

Rabah e Dabah (2004a) investigaram a concentração de biomassa e as características do biofilme em dois reatores anaeróbios de leito fluidificado. A fonte de carbono foi metanol (3000 mg. $\left.\mathrm{L}^{-1}\right)$ e a fonte de nitrogênio foi nitrato de potássio $\left(1000 \mathrm{mg} \mathrm{N}-\mathrm{NO}^{3} \cdot \mathrm{L}^{-1}\right) . \mathrm{O}$ reator foi preenchido com areia de granulometria uniforme com $0,84 \mathrm{~mm}$ de diâmetro médio. Foram avaliados os efeitos da variação de dois parâmetros: a velocidade superficial e o aumento da taxa de carregamento orgânico. A média da concentração da biomassa decresceu conforme o acréscimo da velocidade superficial que variou entre $45-65 \mathrm{~m} \cdot \mathrm{h}^{-1}$, para todas taxas de carregamento de nitrogênio aplicadas $\left(6,8,12\right.$ e 16 kg.N.m ${ }^{-3}$ leito.d $\left.{ }^{-1}\right)$.

A adesão e o crescimento da biomassa influenciaram no tamanho e na densidade das biopartículas, que contribuíram com uma maior segregação no leito. Testes de atividade metanogênica foram conduzidos empregando ácido acético, propiônico e butírico. Estes testes indicaram que a atividade total era mais elevada nas amostras coletadas nos níveis superiores do reator. Isto pode ser explicado pelos valores de densidade menores do biofilme nestes pontos e menor interferência dos fenômenos de limitação de transferência de massa. Com porcentagem de fluidificação mais baixa (25\%), houve aumento de biomassa, indicando que 
porcentagens de expansão mais elevadas provocam cisalhamento e dificultam o desenvolvimento do biofilme. Para porcentagens menores que $10 \%$, houve diminuição da atividade microbiana, acúmulo de ácidos voláteis no sistema, com redução do $\mathrm{pH}$ e diminuição da remoção da matéria orgânica.

Nos reatores em que a biomassa é suspensa, onde o TDH é elevado, a sobrecarga no sistema pode provocar esmaecimento da biomassa. Isto, por sua vez, conduz à perda de eficiência. Reatores de leito fixo, expandido e fluidificado podem suportar TCOs mais elevadas. Em comparação com um (Reator Tanque de Mistura Completa) CSTR, reatores com biomassa aderida são mais estáveis. A Tabela 3.5 apresenta os valores de taxas de carregamento recomendadas para várias configurações de reatores. O RALF aparentemente é capaz de suportar a taxa de carregamento máxima comparada a outros reatores de alta taxa.

Cuenca et al. (2006) avaliaram o desempenho de um RALF na remoção hidrocarbonetos aromáticos (benzeno, etil - benzeno, tolueno, e o xileno) comuns no combustível diesel, que provocam sérios danos ambientais quando lançados em corpos receptores. A água residuária sintética foi preparada com concentrações de 100, 200 e 300 mg.L $\mathrm{L}^{-1}$, sendo o diesel a única fonte do carbono. O meio suporte foi constituído de carvão ativado e as remoções de DQO estiveram situadas entre 61,9 e $84,1 \%$. 
Tabela 3.5 - Características de diferentes tipos de reatores.

\begin{tabular}{ccccccc}
\hline $\begin{array}{c}\text { Tipo de } \\
\text { reator }\end{array}$ & $\begin{array}{c}\text { Tempo de } \\
\text { partida } \\
(\mathrm{d})\end{array}$ & $\begin{array}{c}\text { Recirculação } \\
\text { do efluente }\end{array}$ & $\begin{array}{c}\text { Separador } \\
\text { de sólido } \\
\text { gás }\end{array}$ & $\begin{array}{c}\text { Meio } \\
\text { suporte }\end{array}$ & $\begin{array}{c}\text { TCO típica } \\
(\mathrm{kg} . \text { DQO.m }\end{array}$.dia $\left.^{-1}\right)$ & $\begin{array}{c}\text { TDH } \\
(\mathrm{d})\end{array}$ \\
\hline CSTR & - & Não & Não & $\begin{array}{c}\text { Não } \\
\text { essencial } \\
\text { Não }\end{array}$ & $0,25-3$ & $10-60$ \\
Contato & - & Não & Não & $\begin{array}{c}\text { essencial } \\
\text { Não } \\
\text { essencial }\end{array}$ & $10-30$ & $0,25-4$ \\
UASB & $4-16$ & Não & Essencial & $12-15$ \\
$\begin{array}{c}\text { Filtro } \\
\text { anaeróbio }\end{array}$ & $3-4$ & Não & Beneficia & Essencial & $1-40$ & $0,5-12$ \\
Leito & $3-4$ & Sim & Não & Essencial & $1-50$ & $0,2-5$ \\
expandido \\
RALF
\end{tabular}

Fonte: (RAJESHWARI et al., 2000)

Além do emprego do RALF para remoção de material carbonáceo, embora ainda bastante escassos, alguns estudos demonstram que o reator de leito fluidificado tem grande potencial para realizar também a desnitrificação, podendo operar com altas concentrações de nitrogênio. A Tabela 3.6 apresenta alguns estudos realizados com RALF na desnitrificação.

Tabela 3.6 - Comparação de alguns estudos sobre desnitrificação utilizando RALF.

\begin{tabular}{|c|c|c|c|c|}
\hline \multirow{2}{*}{$\begin{array}{l}\text { Forma de } \\
\text { nitrogênio }\end{array}$} & \multirow{2}{*}{$\begin{array}{c}\text { Temperatura } \\
\left({ }^{\circ} \mathrm{C}\right)\end{array}$} & \multirow{2}{*}{$\begin{array}{c}\text { Carbono - metanol } \\
\left(\mathrm{mg} \cdot \mathrm{L}^{-1}\right)\end{array}$} & \multicolumn{2}{|c|}{ Taxa de desnitrificação } \\
\hline & & & g.N.g ${ }^{-1} \cdot S S V^{-1} \cdot d^{-1}$ & kg.N.m $\mathrm{m}^{-3}$.leito $\mathrm{d}^{-1}$ \\
\hline $\mathrm{N}-\mathrm{NO}_{3}$ & $18-23$ & $5-100$ & - & $5,4-20,70$ \\
\hline $\mathrm{N}-\mathrm{NO}_{3}$ & - & $6.6-30$ & $0,033-0,243$ & $0,69-3,28$ \\
\hline $\mathrm{N}-\mathrm{NO}_{3}$ & 30 & $15-300$ & $0,141-2,575$ & $3,23-18,70$ \\
\hline $\mathrm{N}-\mathrm{NO}_{3}$ & 20 & 20 & 0,10 & 3,5 \\
\hline $\mathrm{N}-\mathrm{NO}_{3}$ & - & $676-1500$ & - & $11,8-17,7$ \\
\hline $\mathrm{N}-\mathrm{NO}_{3}$ & 23 & 1000 & 0,41 & 12 \\
\hline
\end{tabular}

Fonte: (RABAH; DAHAB, 2004b) 
Hwang et al. (2006) empregaram reator de leito fluidificado para desnitrificação, empregando etanol como doador de elétrons. Após a inoculação, houve desenvolvimento do biofilme no meio suporte, o qual era constituído por partículas de carvão ativado. Após quatro meses de operação do sistema com TDH de aproximadamente 48 horas, foram observadas mudanças significativas na comunidade microbiana. As fases anteriores foram caracterizadas como período de seleção, acompanhado de pequena diversidade com predominância de Azoarcus. Algumas modificações nas condições operacionais tais como pH e concentração de nutrientes limitantes, incrementaram rapidamente a diversificação de espécies, com desenvolvimento de seqüências como Dechloromonas, Pseudomonas, e Hydrogenophaga. Apenas depois de 60 dias do início da operação do reator, com desenvolvimento da biomassa o reator passou a apresentar estabilidade operacional.

\subsubsection{Remoção de fenol em reator de leito fluidificado}

Costa (1994) avaliou o desempenho do reator anaeróbio de leito fluidificado preenchido com carvão ativado para tratamento de água residuária contendo fenol. O reator foi construído em tubo de PVC, com $164 \mathrm{~cm}$ de comprimento e $49 \mathrm{~mm}$ de diâmetro interno, e com um decantador de $46 \mathrm{~cm}$ de comprimento e $49 \mathrm{~mm}$ de diâmetro interno. Foi feita a caracterização porosimétrica do carvão $(1,00-2,38 \mathrm{~mm})$, avaliando os efeitos do meio suporte sobre o sistema. A autora constatou que a capacidade de adsorção do carvão foi alterada de acordo com as características do adsorbato, e que a capacidade de adsorção do fenol pelo carvão ativado variava com a concentração de carvão, o tempo de contato e com o pH da solução. A eficiência de remoção de fenol variou de 65,7 a 99\% e de DQO variou de 
50,3 a 94\%. A carga orgânica aplicada variou de 0,37 a $9,79 \mathrm{~kg} \cdot$ DQO. $\mathrm{m}^{-3} \cdot \mathrm{dia}^{-1}$ e o TDH de 0,05 a 0,16 dias.

Sancinetti (2004) estudou a degradação de fenol em reator anaeróbio de leito fluidificado. Foram realizados testes preliminares em batelada, a fim de verificar o desempenho de diferentes inóculos na degradação do fenol. Foi feita comparação entre lodo proveniente de abatedouro de aves, imobilizado em espuma de poliuretano e empregado para tratamento da vinhaça, com lodo proveniente de resíduo de suinocultura (sem prévia adaptação ao fenol). O lodo de suinocultura apresentou melhores resultados, passando posteriormente por etapa de adaptação ao fenol. Ensaios em batelada também auxiliaram na obtenção dos parâmetros cinéticos de consumo de fenol. O estudo cinético mostrou que a maior velocidade de reação foi obtida para a concentração de fenol de $355 \mathrm{mg} \cdot \mathrm{L}^{-1}$. No RALF o meio suporte empregado para imobilização da biomassa foi constituído de partículas de poliestireno $(2,2 \mathrm{~mm})$. Foram avaliadas concentrações de fenol de $50 \mathrm{mg} . \mathrm{L}^{-1}$ a $300 \mathrm{mg} . \mathrm{L}^{-1} \mathrm{com}$ tempo de detenção hidráulica de 24h, parâmetros tais como, concentração de fenol, DQO, alcalinidade, ácidos voláteis, $\mathrm{pH}$ e temperatura, auxiliaram a avaliação do desempenho do sistema. O estudo verificou eficiência de remoção de fenol superior a 95\% e remoção de DQO acima de $85 \%$. As observações em microscópio eletrônico de varredura mostraram adesão satisfatória dos microrganismos e a análise em microscópio ótico indicou presença de bacilos retos, ovalados, víbrios, espiralados e cocos, além da presença de morfologias semelhantes a Methanosaeta sp. em todas as fases de operação do reator.

Sader (2005) estudou a formação de biofilme em partículas poliméricas usadas como meio suporte em reatores anaeróbios de leito fluidificado. Foram testados 3 suportes poliméricos: poliestireno, PET e PVC, os quais sofreram tratamento ácido adequado, com intuito de favorecer a adesão microbiana. Os reatores foram inoculados com lodo proveniente de reator UASB que tratava resíduo de suinocultura, adaptado à degradação do fenol por 150 
dias. A concentração de fenol variou de 100 a $400 \mathrm{mg} . \mathrm{L}^{-1}$ na alimentação de cada sistema, apresentando resultados de remoção de fenol de 97\%, 98\% e 97,5\% e remoção de DQO de $84 \%, 88,5 \%$ e $87 \%$, respectivamente, para os reatores com poliestireno, PET e PVC, os quais operaram com tempo de detenção hidráulica de 22 h, 10,6 h e 20,4 h, respectivamente. A quantificação de polímeros extracelulares mostrou melhores resultados para as partículas de PVC que apresentou 0,2 mg.Carboidrato por g.Partícula e 0,06 mg.Proteína por g.Partícula. No entanto, deformações nessas partículas prejudicaram o desempenho do reator, definindo como melhor suporte as partículas de PET.

Amorim (2007) estudou a viabilidade do uso de reator anaeróbio de leito fluidificado (RALF) operado sob condições de aumento progressivo da carga orgânica no tratamento de água residuária sintética contendo fenol como única fonte de carbono. O reator foi construído em acrílico com altura de $190 \mathrm{~cm}$ e diâmetro interno de $5 \mathrm{~cm}$, e volume total de $4192 \mathrm{~cm}^{3}$. O meio suporte foi constituído por partículas de poliestireno $(2,2 \mathrm{~mm})$. O inóculo utilizado foi lodo de abatedouro de suínos, o tempo de detenção hidráulica (TDH) foi 24 h, o RALF foi operado a $30 \pm 1{ }^{\circ} \mathrm{C}$ durante 182 dias. A adaptação do inóculo ocorreu no próprio reator, tendo permitido uma partida rápida com duração de apenas 14 dias. As concentrações de fenol tratadas foram de $50 \mathrm{mg} . \mathrm{L}^{-1}$ a $700 \mathrm{mg} . \mathrm{L}^{-1}$, com taxas de carregamento orgânico aplicadas de 0,09 a $1,29 \mathrm{~kg} \cdot$ fenol. $\mathrm{m}^{-3} \cdot \mathrm{dia}^{-1}$. O pH variou entre 6,59 e 8,21 para todo o sistema. As concentrações de alcalinidade a bicarbonato (AB) afluente e efluente foram $180 \mathrm{mg} . \mathrm{L}^{-1} \mathrm{e} 294$ mg.L $\mathrm{L}^{-1}$, respectivamente. Foram constatadas eficiências de remoção de fenol e de DQO superiores a $90 \%$ e $88 \%$, respectivamente. De maneira geral, os resultados mostraram a potencialidade do sistema proposto em degradar efluentes contendo fenol. 


\subsection{CONSIDERAÇÕES FINAIS DA REVISÃO BIBLIOGRÁFICA}

Entre as diversas propostas apresentadas observa-se o emprego de culturas puras e mistas na degradação de fenol. Para o primeiro tipo, há maior probabilidade em se elucidar a rota metabólica envolvida no processo de redução do anel aromático, que, uma vez identificada, vem a enriquecer os estudos a cerca destes compostos. Por outro lado, para tratamento de efluentes, em escala de bancada ou especialmente em escala piloto, torna-se praticamente inviável o isolamento destes microrganismos, de forma que, ao mesmo tempo em que o estudo se aproxima de uma situação real, se incrementam as variáveis que controlam o processo.

A complexidade do processo está relacionada principalmente com a quantidade de variáveis existentes, que são inúmeras; ao exemplo do tipo de aceptor de elétrons (LONDRY; FEDORAK, 1992), para o caso da escolha ser o nitrato, o processo denomina-se desnitrificação e um importante parâmetro a ser determinado é a fonte de carbono (AKUNNA; BIZEAU; MOLETTA, 1993; LEE; WELANDER, 1996; KARIM; GUPTA, 2002), que pode ser ou não acompanhada de co-substratos (EIROA et al., 2005), o estabelecimento da relação entre carbono e nitrogênio, é de vital importância para que se tenha êxito, tanto na desnitrificação, quanto na remoção de matéria orgânica (HER; HUANG, 1995; SANTOS, 2003; RUIZ; JEISON; CHAMY, 2006).

Alguns estudos mostram a utilização de fenol como fonte de carbono no processo de desnitrificação, verificando aspectos como a interação desnitrificação e a metanogênese (FANG; ZHOU 1999), e a realização simultânea da nitrificação (tanque de aeração) e desnitrificação de (AUN, 2001; DOMBROSKI, 2003; QUEIROZ, 2006). Outros estudos procuram avaliar os resultados da remoção de fenol e nitrogênio em um determinado tipo de 
reator anóxico, tal qual o estudo realizado por Sarfaraz et al. (2004) em um Reator de Batelada Seqüencial (SBR), ou o apresentado por Zhu et al. (2006), em um reator tipo UASB.

Desta forma, observa-se o emprego de reatores descontínuos, que, ao passo que oferecem vantagem por apresentarem maior flexibilidade operacional, onde, conforme haja necessidade, é possível maior variabilidade na duração de cada etapa ou fase. Contudo, ao passo que os reatores em batelada oferecem este benefício, se contrapõe ao fato de que, o lançamento de efluentes não se dá de forma intermitente, inclusive em indústrias, de forma que os sistemas contínuos se adequam melhor, sobretudo os sistemas de alta taxa.

Nas duas últimas décadas têm-se realizado estudos no tocante a remoção de fenol em reatores de alta taxa, a exemplo do reator de leito fluidificado, no qual foram testados alguns parâmetros importantes como os efeitos das variantes de um único meio suporte (carvão ativado) sobre o sistema (COSTA, 1994), a implicação nos resultados de eficiência de degradação de fenol conforme tipo de inóculo (SANCINETTI, 2004), o emprego de diversos tipos de meios suporte (poliestireno, PET e PVC) (SADER, 2005), alteração do tipo de adaptação e partida, concomitante a observância de colapso do sistema conforme o aumento progressivo das concentrações de fenol no sistema (AMORIM, 2007). Entretanto, nenhum destes estudos contemplou a realização do processo de desnitrificação, simultânea a remoção de fenol, tal qual, está entre os objetivos do presente trabalho. 


\section{MATERIAL E MÉTODOS}

\subsection{REATOR ANAERÓBIO DE LEITO FLUIDIFICADO}

O reator foi construído em acrílico transparente, cuja espessura média era de $5 \mathrm{~cm}$, com dimensões equivalentes a $190 \mathrm{~cm}$ de altura e $5,3 \mathrm{~cm}$ de diâmetro interno, totalizando em um volume total de $4192 \mathrm{~cm}^{3}$, dos quais cerca de $44 \%\left(1831 \mathrm{~cm}^{3}\right)$ foram ocupados pelo meio suporte, na situação de leito fixo. O reator foi dotado de cinco amostradores intermediários ao longo do seu comprimento que distam em $20 \mathrm{~cm}, 40 \mathrm{~cm}, 70 \mathrm{~cm}, 110 \mathrm{~cm}$ e $160 \mathrm{~cm}$, da base do reator. A Figura 4.1 mostra um esquema ilustrativo do aparato experimental (sem escala) do sistema que compõe a instalação piloto do reator anaeróbio de leito fluidificado.

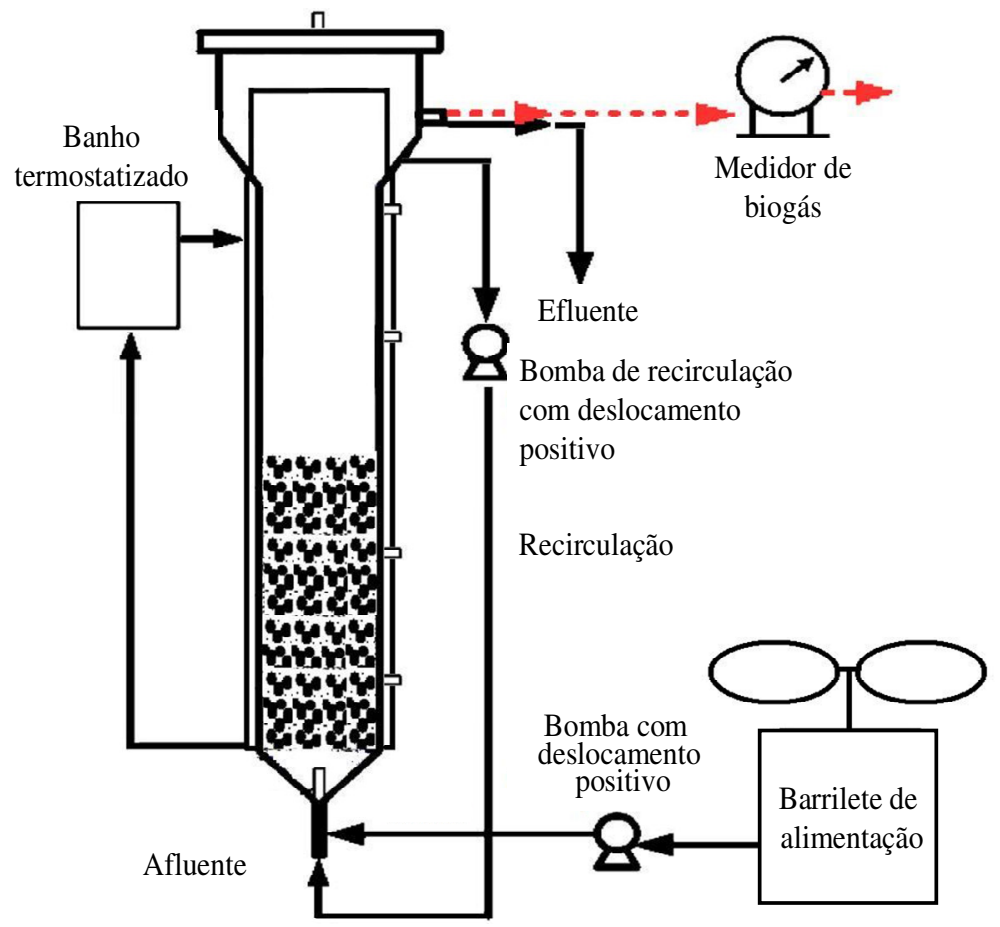

Figura 4.1 - Esquema ilustrativo do aparato experimental. 
A temperatura do sistema foi controlada por banho ultratermostatizado (Marconi, modelo 184), através de encamisamento, no qual a temperatura foi mantida a $30 \pm 1{ }^{\circ} \mathrm{C}$. A Figura 4.2 mostra o reator em funcionamento.

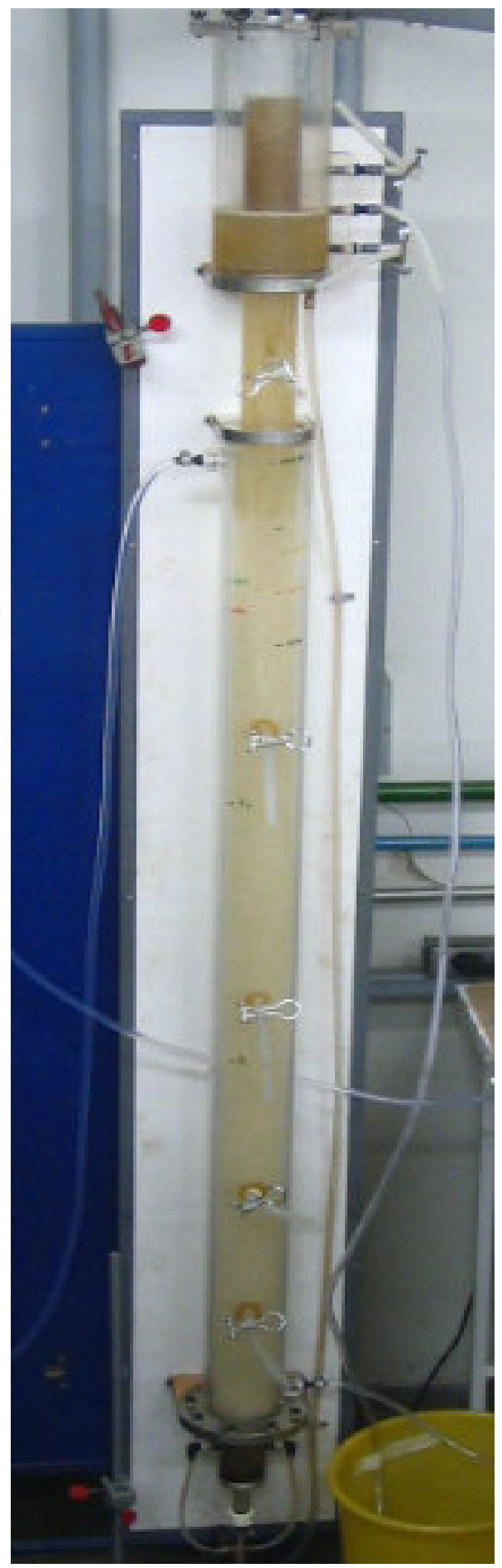

Figura 4.2 - Reator anaeróbio de leito fluidificado. 
A Figura 4.3 mostra em detalhes o headspace, onde foi realizada captação do biogás e coleta do efluente. A Figura 4.4 exibe o barrilete de alimentação, mantido através de balões de látex preenchidos de $\mathrm{N}_{2}$ (a fim de garantir o meio anóxico).

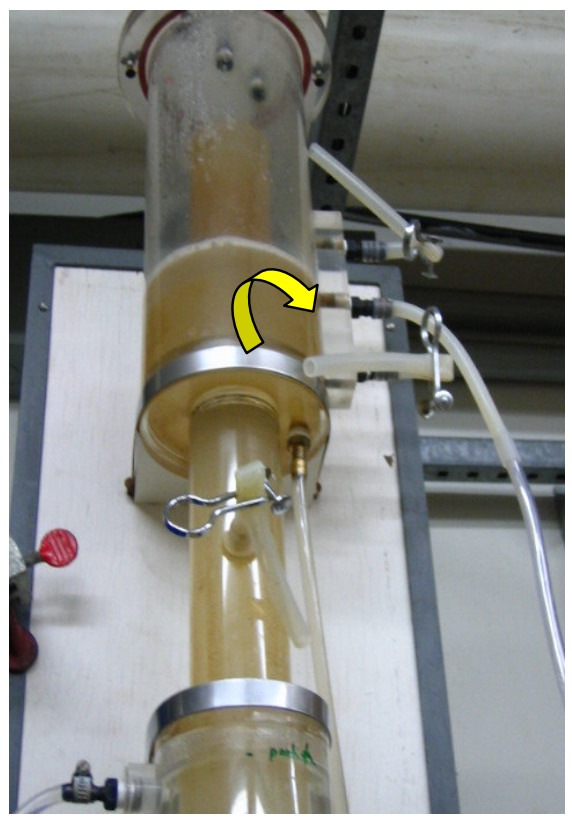

Figura 4.3 - Ponto de coleta do biogás e do efluente, indicado pela seta no headspace.

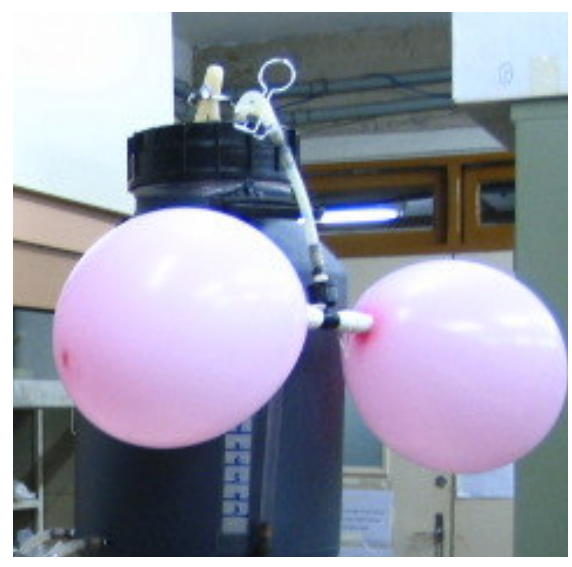

Figura 4.4 - Barrilete de alimentação. 


\subsection{INÓCULO}

O inóculo utilizado no reator de leito fluidificado, foi proveniente de reator UASB, localizado na UNESP de Jaboticabal, que atua no tratamento de água residuária de suinocultura.

\section{3. $\quad$ SUPORTE PARA IMOBILIZAÇÃO DA BIOMASSA}

O meio suporte para imobilização da biomassa era constituído por poliestireno (Figura 4.5), caracterizado por Martinelli (2003), com dimensões de 2,2 x 2,2 mm (comprimento por diâmetro), densidade de 1,05 g. $\mathrm{cm}^{-3}$ e velocidade mínima de fluidificação de $0,74 \mathrm{~cm} \cdot \mathrm{s}^{-1}$.

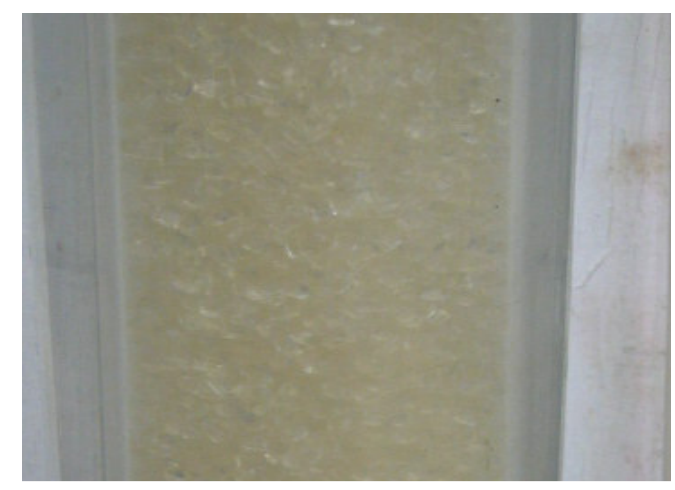

Figura 4.5 - Partículas de poliestireno no reator de leito fluidificado.

As partículas de poliestireno foram previamente ativadas de acordo com Tavares (1992), com o intuito de aumentar a rugosidade e a porosidade da superfície do material, 
facilitando a aderência da biomassa no meio suporte. O procedimento consistiu em submergir as partículas em solução sulfocrômica por cerca de 40 minutos. Em seguida o material foi lavado com água em abundância e mergulhado em ácido nítrico concentrado por 50 minutos, onde novamente foi lavado por várias vezes. Ao final destes processos as partículas permaneceram em estufa de secagem a $50{ }^{\circ} \mathrm{C}$. O processo completo foi repetido por quatro vezes.

\section{4. ÁGUA RESIDUÁRIA SINTÉTICA}

A água residuária foi preparada empregando fenol como principal fonte de carbono, e nitrato de potássio como fonte de nitrogênio, cuja relação foi estabelecida baseando-se no trabalho de Thomas et al. (2002), que utilizou 5 mols de $\mathrm{KNO}_{3}$ por mol de fenol, permitindo assim, que a relação de carbono orgânico proveniente do fenol e $\mathrm{N}-\mathrm{NO}_{3}$ fosse de aproximadamente 1. A seguir, a Tabela 4.1 mostra a composição da solução nutriente e a Tabela 4.2 a composição da solução traço de metais. Vale ressaltar que, na Tabela 4.1, observa-se adição de $2 \mathrm{~mL}$ de solução traço de metais por litro de solução nutriente, de maneira que a Tabela 4.2, apresenta a concentração das substâncias traço por litro de solução preparada, não sendo, portanto, a concentração final no barrilete, já que apenas $2 \mathrm{~mL}$ eram utilizados, diluindo assim, as concentrações citadas na Tabela 4.2. 
Tabela 4.1 - Composição da solução nutriente.

\begin{tabular}{cll}
\hline \multicolumn{1}{c}{ Solução } & \multicolumn{1}{c}{ Substância } & Concentração \\
\hline & $\mathrm{KH}_{2} \mathrm{PO}_{4}$ & $4 \mathrm{~g} . \mathrm{L}^{-1}$ \\
& $\mathrm{MgSO}_{4}$ & $0,1 \mathrm{~g} . \mathrm{L}^{-1}$ \\
Solução nutriente & Extrato de levedura & $0,5 \mathrm{~g} \cdot \mathrm{L}^{-1}$ \\
& Solução traço de metais & $2 \mathrm{~mL} . \mathrm{L}^{-1}$ \\
\hline
\end{tabular}

Tabela 4.2 - Composição da solução traço de metais

\begin{tabular}{ccc}
\hline \multicolumn{1}{c}{ Solução } & \multicolumn{1}{c}{ Substância } & Concentração \\
\hline & $\mathrm{FeSO}_{4} \cdot 7 \mathrm{H}_{2} \mathrm{O}$ & $1,36 \mathrm{~g} . \mathrm{L}^{-1}$ \\
& $\mathrm{Na}_{2} \mathrm{MoO}_{4} \cdot 2 \mathrm{H}_{2} \mathrm{O}$ & $0,24 \mathrm{~g} . \mathrm{L}^{-1}$ \\
& $\mathrm{CuSO}_{4} \cdot 5 \mathrm{H}_{2} \mathrm{O}$ & $0,25 \mathrm{~g} . \mathrm{L}^{-1}$ \\
Solução traço de metais & $\mathrm{ZnSO}_{4} \cdot 7 \mathrm{H}_{2} \mathrm{O}$ & $0,58 \mathrm{~g} . \mathrm{L}^{-1}$ \\
& $\mathrm{NiSO}_{4} \cdot 6 \mathrm{H}_{2} \mathrm{O}$ & $0,11 \mathrm{~g} . \mathrm{L}^{-1}$ \\
& $\mathrm{MgSO}_{4} \cdot \mathrm{H}_{2} \mathrm{O}$ & $1,01 \mathrm{~g} . \mathrm{L}^{-1}$ \\
& $\mathrm{H}_{2} \mathrm{SO}_{4}$ & $1 \mathrm{~mL} \cdot \mathrm{L}^{-1}$ \\
\hline
\end{tabular}

A solução nutricional foi preparada baseada na proposta de Sarfaraz et al. (2004), tendo sida promovida a modificação na concentração de extrato de levedura. Os autores adicionaram 1 g.L. $\mathrm{L}^{-1}$ e, neste experimento, foi empregado 0,5 g. $\mathrm{L}^{-1}$, valor este também utilizado por Amorim (2007).

Durante a operação do reator, as concentrações de fenol (principal fonte de carbono) foram aumentadas progressivamente para concentrações que variaram entre 52 a $518 \mathrm{mg} . \mathrm{L}^{-1}$, bem como as concentrações de nitrato de potássio (principal fonte de nitrogênio) que inicialmente era $45 \mathrm{mg} . \mathrm{L}^{-1}$ evoluindo para $362 \mathrm{mg} . \mathrm{N}-\mathrm{NO}_{3} \mathrm{~L}^{-1}$ no estágio final de operação 
do sistema. Vale ressaltar que todos os outros componentes da água residuária sintética permaneceram inalterados durante todo experimento.

\subsection{ADAPTAÇÃO DO INÓCULO À ÁGUA RESIDUÁRIA E INÍCIO DA OPERAÇÃO}

Um dos maiores desafios na utilização de processos anaeróbios é a partida do sistema, que pode levar até meses, dependendo da estratégia adotada. Isto ocorre porque o metabolismo anaeróbio é lento, sendo necessário um período de adaptação dos microrganismos ao substrato, caso o inóculo empregado não tenha sido submetido em contato com a fonte de carbono imposta. A formação e o desenvolvimento do biofilme são fatores preponderantes para o sucesso do tratamento (YANGA et al., 2004).

A estratégia de partida e a adaptação adotada neste trabalho foram realizadas de maneira semelhante à utilizada por Amorim (2007), que consistiu, basicamente, no ajuste das condições fluidodinâmicas do reator, sendo que a velocidade mínima de fluidificação das partículas de poliestireno foi $0,74 \mathrm{~cm} \cdot \mathrm{s}^{-1}$ e a velocidade aplicada foi de $0,962 \mathrm{~cm} \cdot \mathrm{s}^{-1}(1,3$ vezes maior). Esta velocidade ascensional foi imposta através de uma bomba de recirculação (ECOSAN - Bomba dosadora), cuja vazão variou de 10 a 200 L.h ${ }^{-1}$ e pressão de 6 kg.cm ${ }^{-2}$.

Com adição de $1000 \mathrm{mg}$ de meio suporte, o reator atingiu altura de leito fixo igual a $83 \mathrm{~cm}$. Após a bomba dosadora de recirculação ser acionada, com vazão de $76 \mathrm{~L} \cdot \mathrm{h}^{-1}$, o leito atingiu altura correspondente a $132 \mathrm{~cm}$.

Após os ajustes hidrodinâmicos, o reator foi esvaziado e a mangueira de sucção da bomba de recirculação foi conectada a um barrilete, com água residuária sintética contendo 50 
mg.L ${ }^{-1}$ de fenol, 38 mg.L $L^{-1}$ de $\mathrm{N}-\mathrm{NO}_{3}$ e $10 \%$ de lodo (percentual relacionado ao volume total do reator, ou seja, aproximadamente $420 \mathrm{~mL}$ de lodo) para inoculação. A saída do efluente no topo do reator foi igualmente conectada ao barrilete permitindo a recirculação da água residuária e do inóculo no reator. O headspace do barrilete foi purgado com $\mathrm{N}_{2}(100 \%)$. A Figura 4.6 ilustra como foi funcionamento do reator durante o período de adaptação.

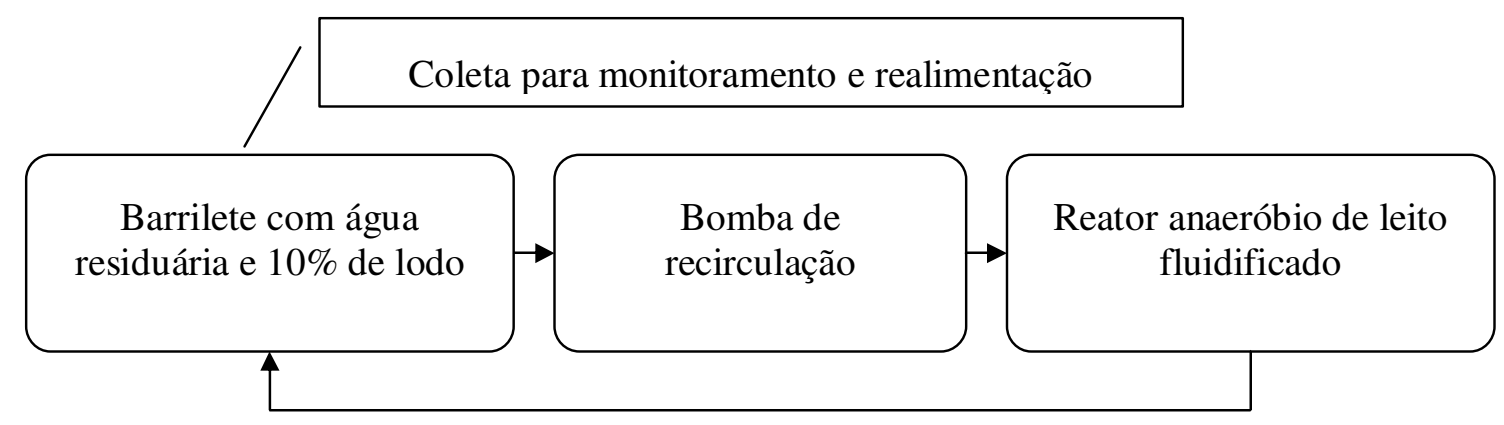

Figura 4.6 - Fluxograma da água residuária, referente ao período de adaptação.

Durante o processo de adaptação (14 dias), o reator foi operado em circuito fechado, funcionando semelhantemente a um reator de batelada alimentada, pois, além de permanecer em recirculação, frequentemente os valores das concentrações de fenol e $\mathrm{N}-\mathrm{NO}_{3}$ eram monitorados, e à medida que estes diminuíam eram novamente repostos, juntamente com a solução nutricional, admitindo que esta também havia sido degradada.

Após o término do período de adaptação, foi dado início à primeira fase, com alimentação contínua no reator. A vazão média de alimentação foi em torno de $176 \mathrm{~mL} \cdot \mathrm{h}^{-1}$, realizada através de uma bomba dosadora da marca Dositec, este valor foi estabelecido através da consideração de que o TDH foi pré-estabelecido com valor de 24 horas, considerando um volume total do reator de $4192 \mathrm{~cm}^{3}$.

Para melhor compreensão da análise dos dados, a operação do reator foi dividida em cinco fases (Tabela 4.2), que foram alteradas principalmente em função das concentrações de fenol e de nitrato, e dos respectivos resultados de eficiências de remoção. 
Tabela 4.3 - Fases de operação do RALF

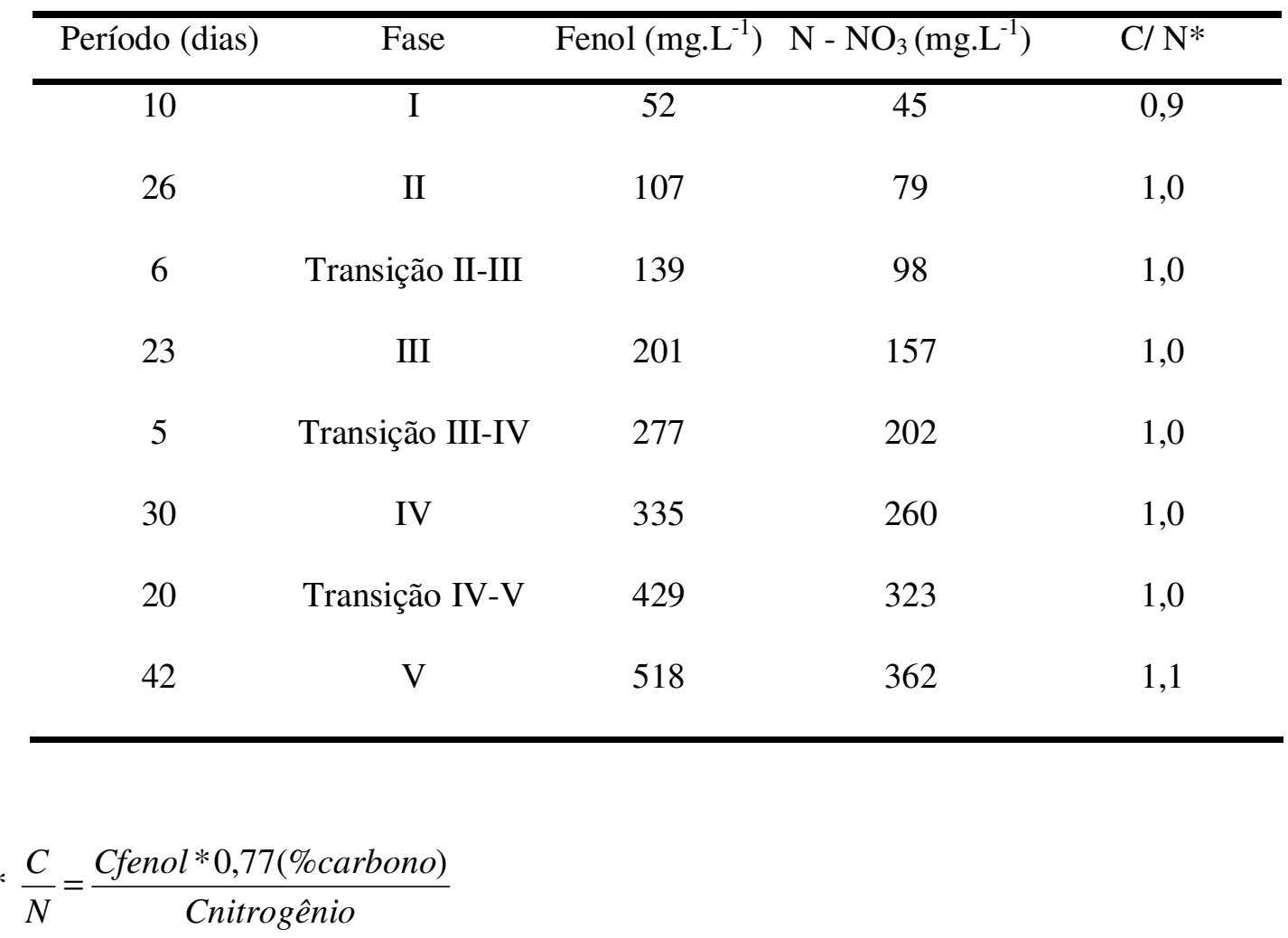

Onde:

$\mathrm{C} / \mathrm{N}$ - relação entre o carbono proveniente do fenol e o nitrogênio proveniente do nitrato de potássio;

Cfenol - concentração de fenol afluente;

0,77 - percentual de carbono em um mol de fenol;

Cnitrogênio - concentração de nitrogênio afluente.

\subsection{MÉTODOS ANÁLITICOS}

O monitoramento do sistema foi efetuado através de análises físico-químicas, realizadas periodicamente. As análises de $\mathrm{pH}$, DQO, Sólidos Voláteis Totais (SVT), Sólidos 
Suspensos Voláteis (SSV), $\mathrm{N}-\mathrm{NO}_{2}$ e $\mathrm{N}-\mathrm{NO}_{3}$ foram realizadas de acordo com APHA: Standard Methods for the Examination of Water and Wastewater (1995).

A concentração de fenol foi medida através do método da CETESB L5.125 Determinação de fenóis em águas - Método colorimétrico da 4 amino - antipirina. (CETESB, 1990). O método fotométrico direto para compostos fenólicos tem precisão para obtenção de valores superiores a $1,0 \mathrm{mg} \cdot \mathrm{L}^{-1}$.

A análise de Ácidos Voláteis Totais (AVT) foi feita seguindo a metodologia proposta por Dilalo e Albertson (1961), enquanto a avaliação de Alcalinidade Bicarbonato (AB) foi determinada conforme metodologia modificada por Ripley et al. (1986).

\subsubsection{Caracterização microbiológica do biofilme anaeróbio}

A morfologia das bactérias e a análise estrutural do biofilme foram avaliadas em microscópio eletrônico de varredura (Digital Scanning Microscope DSM 960, ZEISS), do Instituto de Física de São Carlos da Universidade de São Paulo.

A metodologia adotada para preparação dos suportes para MEV foi adaptada para biofilmes microbianos por Araújo (1995). 


\subsubsection{Determinação da produção de metano}

A produção de biogás no reator foi medida por deslocamento de líquido (solução de $\mathrm{NaOH})$ em dispositivo externo e coletado em recipiente graduado.

A concentração de metano foi verificada através da técnica de cromatografia gasosa com detector de ionização de chama (FID), utilizando um cromatógrafo modelo GC-17A da marca Shimadzu. As condições de operação foram:

- Cromatógrafo gasoso Shimadzu - 17A;

- Detector - FID;

- Coluna GC - $30 \mathrm{~m}$ x 0,32 mm (diâmetro interno) x 0,25 $\mu \mathrm{m}$ de espessura de biofilme;

- Temperatura do injetor $=90{ }^{\circ} \mathrm{C}$; temperatura do detector $=370{ }^{\circ} \mathrm{C}$;

- Temperatura do forno $=250{ }^{\circ} \mathrm{C}$. O fluxo do gás de arraste $\left(\mathrm{H}_{2}\right)$ foi de $2,0 \mathrm{~mL} \cdot \mathrm{min}^{-1}$. 


\section{RESULTADOS E DISCUSSÃO}

\subsection{ADAPTAÇÃO DA BIOMASSA A ÁGUA RESIDUÁRIA SINTÉTICA}

Após a partida do reator de leito fluidificado, uma parte da biomassa em suspensão que estava em recirculação foi perdida. Este fenômeno está correlacionado à velocidade de utilização do substrato empregado e a produção de biogás. Entretanto, a quantidade de biomassa perdida não impede uma rápida partida e o acúmulo de biomassa em um sistema de alta taxa, como o reator de leito fluidificado. Neste caso específico, a fluidificação gera atrito mecânico, causado pela colisão das partículas. No entanto, é improvável que este mecanismo prejudique de maneira significativa o balanço estabelecido para o crescimento dos microrganismos e o metabolismo da manutenção celular (SHIEH; HSU, 1996), em função das diversas vantagens que esta configuração de reator apresenta, as quais já foram citadas anteriormente.

A Figura 5.1 apresenta as variações das concentrações de fenol, durante o período de adaptação, do inóculo à água residuária. Durante o período de adaptação, o consumo total de uma concentração em torno de $50 \mathrm{mg} . \mathrm{L}^{-1}$ de fenol levou, em média, 48 horas.

Apesar das mudanças nas condições nutricionais, este tempo necessário para degradação dessa concentração inicial foi semelhante ao observado por Amorim (2007). Esse fato pode ser um indicador da eficácia da estratégia de adaptação da biomassa à água residuária que foi realizada no próprio reator, já que tanto o inóculo utilizado pelo autor, como o empregado neste trabalho, não eram adaptados para degradação de compostos aromáticos. 


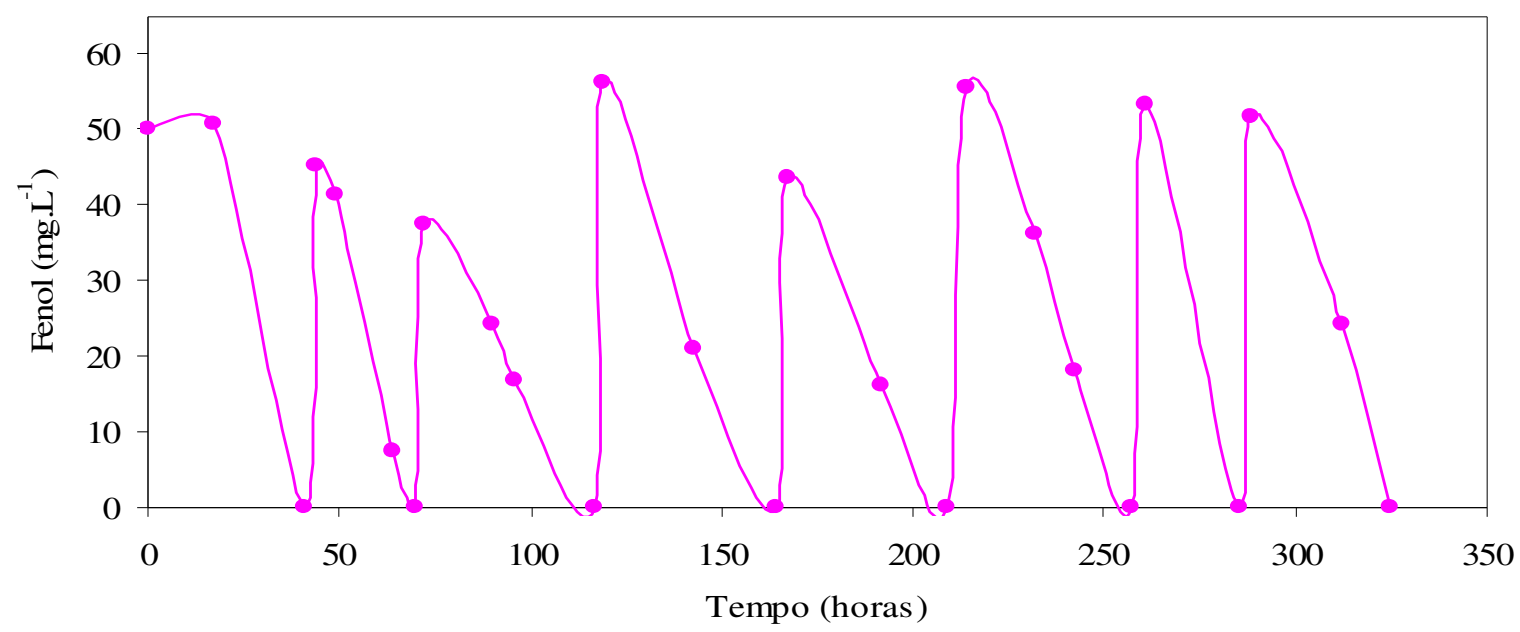

Figura 5.1 - Variação da concentração de fenol durante o período de adaptação.

Hwang et al. (2006) também utilizaram esta estratégia para adaptação da biomassa à água residuária. Os autores inocularam um reator UASB com cultura desnitrificante contendo $6 \mathrm{mM}$ de nitrato de sódio e $340 \mathrm{mg} . \mathrm{L}^{-1}$ de DQO (cuja fonte de carbono era o etanol). O reator foi mantido em recirculação, sem adição de doador de elétrons ou nitrato, por aproximadamente 48 horas. Após 8 horas de inoculação, foi observado formação de gás na superfície do reator, que os autores sugeriram ser atividade desnitrificante.

A alta atividade observada pelos autores, com a formação de biogás após curto tempo de inoculação, pode ser atribuída ao fato de que a cultura utilizada já era desnitrificante e a fonte de carbono facilmente biodegradável, características incomuns a este trabalho.

A Figura 5.2 mostra o comportamento da concentração de nitrogênio sob a forma de nitrato, que durante o período de adaptação, foi em média, $37 \mathrm{mg} \cdot \mathrm{L}^{-1}$. A redução de nitrato foi basicamente concomitante ao consumo do fenol, indicando o equilíbrio entre o doador e o aceptor final de elétrons. 


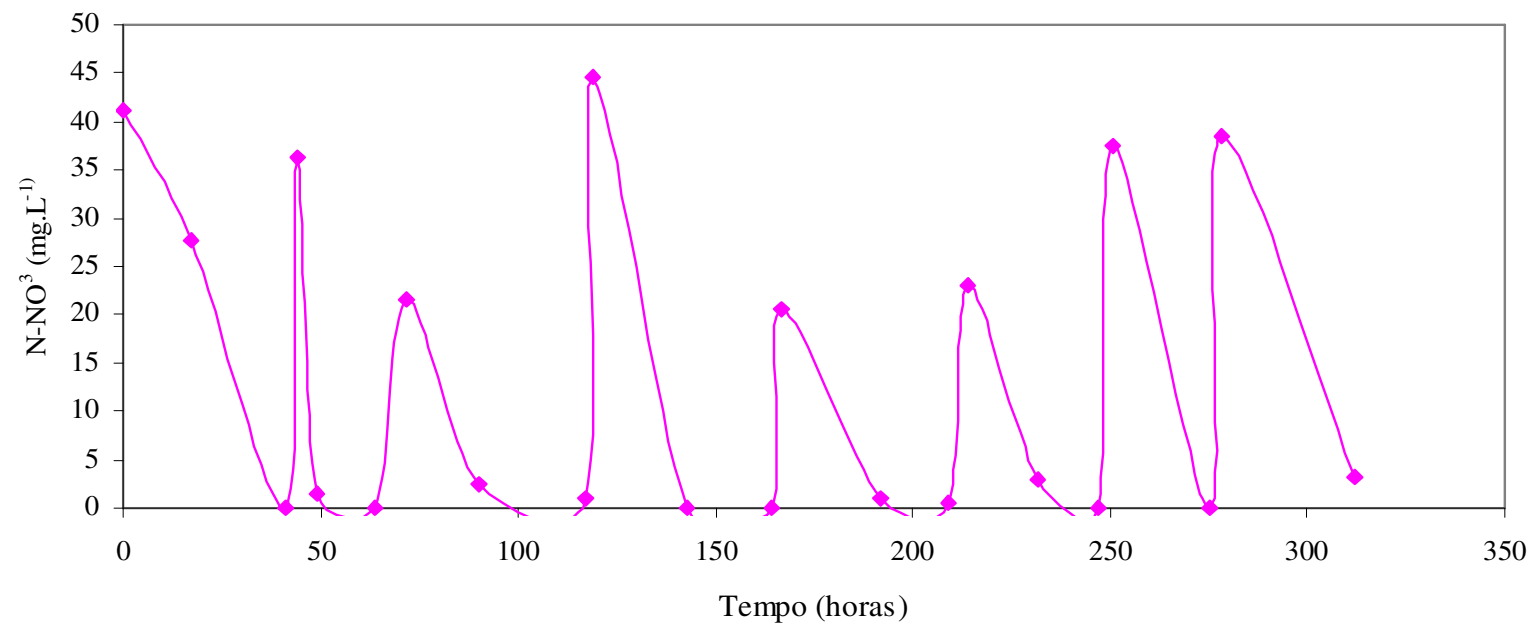

Figura 5.2 - Variação da concentração de nitrato durante o período de adaptação.

\subsection{DEGRADAÇÃO ANAERÓBIA DO FENOL EM REATOR DE LEITO FLUIDIFICADO}

Após 14 dias de adaptação, foi dada partida no sistema, com alimentação contínua. A Figura 5.3 apresenta os valores de concentração de fenol afluente, efluente e de eficiência de remoção de fenol, monitorados durante todo período de operação do sistema.

No intuito de se evitarem sobrecargas no sistema, a concentração média afluente permaneceu semelhante à do período de adaptação, ou seja, com valor médio afluente de 52 mg.L $L^{-1}$. A primeira fase teve duração de apenas dez dias, não tendo sido detectada a presença de fenol no efluente. 


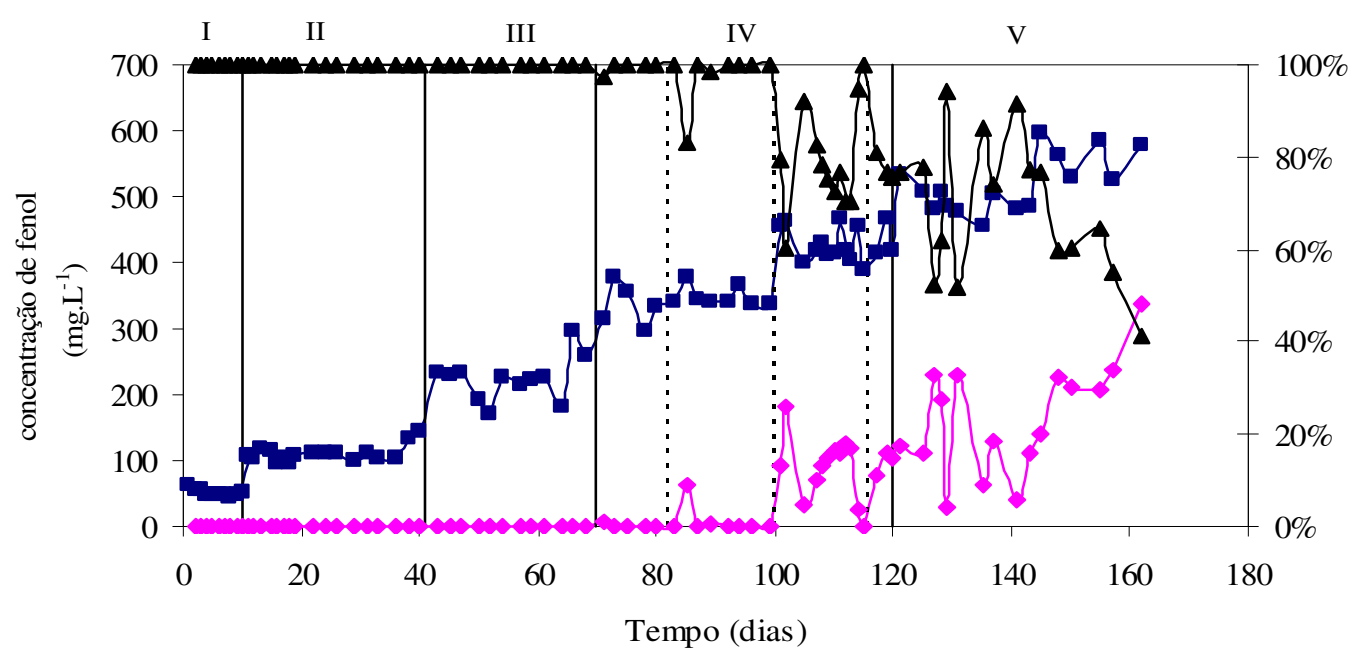

Figura 5.3 - Variação temporal das concentrações de fenol afluente (๘), efluente (»), eficiência de remoção $(\boldsymbol{\Lambda})$, mudanças de fases (-) e dias de realização de limpeza e manutenção do reator (*-").

A segunda e a terceira fase, tiveram duração de 26 e 23 dias e concentração média afluente de $107 \mathrm{mg} . \mathrm{L}^{-1}$ e $201 \mathrm{mg} . \mathrm{L}^{-1}$, respectivamente. A partir da segunda fase, as mudanças de fases ocorreram de maneira gradativa, de forma que, ao invés de duplicar a concentração de fenol inadvertidamente de $100 \mathrm{mg} . \mathrm{L}^{-1}$ para $200 \mathrm{mg} . \mathrm{L}^{-1}$, por exemplo, foram empregadas concentrações intermediárias por curtos períodos de tempo. Sendo assim, ao final da segunda fase o reator passou a ser operado durante seis dias com concentração média afluente de 140 mg.L $\mathrm{L}^{-1}$. Ao se verificar ausência de fenol no efluente durante o período de transição, uma nova fase foi iniciada. Durante o período de operação da segunda e da terceira fase, não foi detectada presença de fenol no efluente, ou seja, a eficiência de remoção de fenol foi de aproximadamente $100 \%$, durante as três primeiras fases.

Ao final da terceira fase, foi iniciada nova transição (com duração de cinco dias), com valor médio afluente de fenol equivalente a $277 \mathrm{mg} . \mathrm{L}^{-1}$, para quarta fase cuja concentração média de fenol foi de $335 \mathrm{mg} . \mathrm{L}^{-1}$. Não foi observada presença de fenol durante esta fase, exceto no $85^{\circ}$ dia. Anteriormente no dia $81^{\circ}$, o reator necessitou ser aberto para 
realização de limpeza na parte superior, ficando apenas em recirculação (sem alimentação contínua) por aproximadamente 15 horas, visando assim, sua recuperação.

Os períodos no qual o reator permaneceu exclusivamente em recirculação, tiveram como função principal cessar a alimentação com água residuária e aumentar o tempo de retenção celular (TRC), no caso de ter havido desprendimento do biofilme do meio suporte. A paralisação do sistema para realização da limpeza acarretou em remoção de parte da biomassa aderida na parte superior do reator (em função de ser uma zona com baixa turbulência) e do biofilme formado no próprio meio suporte. Essa provável perda de biomassa ativa contribuiu para diminuição da remoção da matéria carbonácea. Ao término da limpeza, o reator foi purgado com $\mathrm{N}_{2}$, no intuito de amenizar o impacto das alterações na atmosfera do sistema, e para que as características ambientais fossem restabelecidas.

Nos períodos destinados a recuperação do sistema, a concentração de fenol foi medida para verificação da sua presença no sistema; quando constatado seu consumo, a alimentação contínua era novamente iniciada. Os valores apresentados neste trabalho foram obtidos após 24 horas do reinício da alimentação contínua no sistema, pois este era o tempo necessário para o enchimento do reator, considerando uma vazão de alimentação de 176 $\mathrm{mL} \cdot \mathrm{h}^{-1}$. Desta maneira, foi garantida maior confiabilidade nos dados referentes a recuperação de eficiência na remoção de fenol do reator, que pode ser considerada rápida em se tratando da tamanha perturbação que uma operação como a limpeza provoca no sistema.

Aos 100 dias (após 30 dias de operação na quarta fase) foi iniciada outra transição (valor médio da concentração de fenol afluente de $429 \mathrm{mg} . \mathrm{L}^{-1}$ ) para quinta fase. Neste mesmo dia, houve também necessidade de uma segunda limpeza no reator, que passaram a ser recorrentes (no $116^{\circ}$ dia houve necessidade de uma terceira limpeza).

Essa dificuldade operacional pode ser atribuída à formação de biopolímeros. O lodo formado era bastante floculento, aparentemente com baixa velocidade de sedimentação e 
provocava entupimento da tela de proteção. Essa tela impedia a passagem de partículas de poliestireno para o topo do reator, caso houvesse desprendimento do leito. A presença de partículas do meio suporte no topo do reator pode ser prejudicial ao sistema, por estar livre para entrar na bomba de recirculação e assim danificá-la.

Hwang et al. (2006) observaram que grande parte do biofilme do reator de leito fluidificado cresceu nos grânulos de carvão ativado, de maneira que algumas partículas modificavam sua densidade e passavam a apresentar cor mais clara e se deslocavam para a parte superior do reator. Os autores necessitaram paralisar o sistema por duas vezes, também por um curto período de tempo, entre uma paralisação e outra. A primeira foi no $50^{\circ}$ dia de operação e a outra no $53^{\circ}$ dia. Ambas as interrupções fizeram com que o sistema passasse por períodos de recirculação; sendo 12 e 72 horas, respectivamente. Os autores optaram por instalar, no topo do reator, um dispositivo mecânico responsável pela remoção do excesso de biofilme das partículas arrastadas, de maneira que estas eram novamente introduzidas no reator.

A formação excessiva desse lodo foi igualmente constatada por Ruiz, Jeison e Chamy (2006), que observaram que para relações de DQO/N - $\mathrm{NO}_{3}$ menores que 5, havia necessidade de limpeza que também prejudicou a estabilidade e bom desempenho do sistema, enquanto que, para valores maiores da relação, (10 por exemplo), esse fenômeno não ocorria.

Em ambientes aquáticos naturais, os microrganismos se organizam na forma de biofilmes como estratégia de sobrevivência. Esses biofilmes são constituídos por uma comunidade estruturada de células aderentes a uma superfície inerte ou viva, embebidas numa matriz de substâncias poliméricas extracelulares (EPS). No entanto, há relatos de que, em tratamento biológico anaeróbio, algumas condições ambientais proporcionam a produção bastante elevada desse material polimérico, que é caracterizado por alta viscosidade e consistência gelatinosa, que implica em redução das velocidades de transferência de massa, e 
queda na eficiência de remoção de matéria orgânica. Em suma, a formação de EPS produzidos em processos de tratamento anaeróbios, é indesejável, pois acarreta em problemas operacionais que podem vir a inviabilizar o processo.

Vale ressaltar que, quando a camada desse lodo na tela de proteção não é removida, a perda de carga na bomba de recirculação aumenta e sua eficiência na expansão do leito diminui. A diminuição do leito afeta diretamente a eficiência do sistema, fato que pode ser atribuído ao aumento da taxa de carregamento orgânico no sistema. Isto ocorre porque a taxa de carregamento orgânico efetiva é diretamente proporcional à altura média do leito, onde grande parte das reações ocorre, já que a biomassa está aderida ao mesmo. Em suma, quanto menor a altura do leito, menor o tempo de contato entre o líquido a ser tratado e os microrganismos responsáveis pela degradação, já que as vazões da bomba de recirculação e da bomba de alimentação foram inalteradas. A altura do leito, bem como outras informações referentes a cada fase pode ser vista na Tabela 5.1.

Tabela 5.1 - Valores médios de concentração e remoção de fenol, vazão, TDH e altura de leito, para cada fase ou período de operação.

\begin{tabular}{cccccccc}
\hline Fase & $\begin{array}{c}\text { Fenol } \\
\left({\mathrm{mg} . L^{-1}}^{-1}\right)\end{array}$ & $\begin{array}{c}\text { Eficiência de } \\
\text { remoção }(\%)\end{array}$ & $\begin{array}{c}\text { Vazão } \\
\left(\mathrm{mL} \cdot \mathrm{h}^{-1}\right)\end{array}$ & $\begin{array}{c}\mathrm{H}_{\mathrm{f}}{ }^{\mathrm{a}} \\
(\mathrm{cm})\end{array}$ & $\begin{array}{c}\mathrm{TDH} \\
(\mathrm{h})^{\mathrm{b}}\end{array}$ & $\begin{array}{c}\mathrm{TDHe} \\
(\mathrm{h})^{\mathrm{c}}\end{array}$ & $\begin{array}{c}\text { TCF }^{\mathrm{d}} \\
\left(\mathrm{kg} . \mathrm{fenol}^{-3} \mathrm{mia}^{-1}\right)\end{array}$ \\
\hline I & 52 & $100 \pm 0$ & 170 & 137 & 25 & 18 & 0,07 \\
II & 107 & $100 \pm 0$ & 187 & 134 & 22 & 16 & 0,16 \\
III & 201 & $100 \pm 0$ & 181 & 132 & 23 & 16 & 0,30 \\
IV & 335 & $99 \pm 4$ & 180 & 128 & 23 & 15 & 0,51 \\
IV-V & 429 & $79 \pm 10$ & 175 & 114 & 24 & 14 & 0,72 \\
V & 518 & $69 \pm 15$ & 176 & 126 & 24 & 16 & 0,79 \\
\hline
\end{tabular}

a - $\mathrm{H}_{\mathrm{f}}$ : Altura média da camada do meio suporte em cada fase.

b - TDH: tempo de detenção hidráulica relativo a altura total do reator.

c - TDHe : tempo de detenção hidráulica efetivo relativo a altura da camada de meio suporte.

d - Taxa de Carregamento de Fenol aplicada, referente a altura média do leito, por fase. 
Em função dos problemas operacionais supracitados, o tempo de duração da transição para quinta fase foi maior (20 dias) quando comparado às fases anteriores. $\mathrm{O}$ valor médio de eficiência de remoção de fenol foi de $79 \%$.

Mesmo após a realização da limpeza no sistema, a altura do leito continuou decaindo. Esse fato foi devido ao esforço contínuo da bomba de recirculação, em função da alta perda de carga provocada pelo estreitamento da tela de proteção, preenchida com lodo. $\mathrm{O}$ diafragma da bomba foi danificado, necessitando substituição. Após a realização da manutenção e com altura do leito se mantendo constante, em função do longo tempo de transição, foi iniciada a quinta fase $\left(121^{\circ}\right.$ dia $)$, cujo valor médio afluente da concentração de fenol igual a $518 \mathrm{mg} \cdot \mathrm{L}^{-1}$. Neste momento da pesquisa, a eficiência de remoção de fenol estava em torno de $80 \%$. Logo, foi a primeira mudança de fase na qual, o sistema não estava com remoção máxima da concentração de fenol aplicada.

Como a degradação de qualquer que seja o composto não se limita apenas à avaliação das faixas de concentrações a serem testadas, é interessante que a discussão seja feita também em torno de um outro importante parâmetro, a taxa de carregamento de fenol (TCF) aplicada. Este parâmetro engloba outras medidas cruciais do sistema, já citadas anteriormente, incluindo ainda; vazão aplicada e TDHe, que variam de sistema para sistema. O conhecimento da TCF aplicada é especialmente importante para que fique mais clara a comparação do trabalho atual com outros trabalhos que promoveram remoção de fenol através de tratamento biológico.

De posse da vazão média de alimentação, que foi monitorada ostensivamente, e da altura média ocupada pelo leito em cada fase, o TDH efetivo é calculado, e é possível então, conhecer a TCF aplicada correspondente a cada fase (dados apresentados na Tabela 5.1).

Como pode ser observado na Figura 5.4, os valores da vazão de alimentação apresentam variações, motivadas especialmente pela entrada de ar na bomba e por oscilações 
na rede elétrica que alteram a vazão para qual foi calibrada (este problema foi amenizado com emprego de purgadores de ar). A vazão média, durante toda operação do sistema foi de $179 \pm$ $17 \mathrm{~mL} \cdot \mathrm{h}^{-1}$.

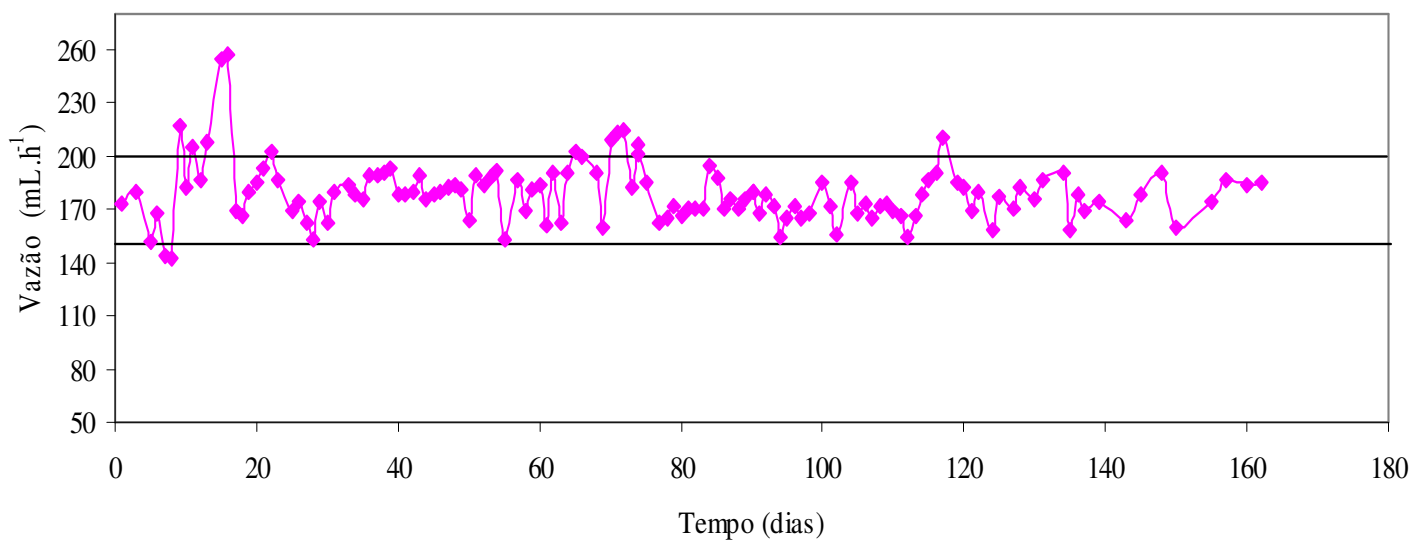

Figura 5.4 - Variação da vazão medida através da coleta do efluente (»).

A Figura 5.5 mostra o acréscimo da taxa de carregamento de fenol e a eficiência de remoção do mesmo ao longo da operação do reator. O sistema operou com TCF aplicada variando entre 0,07 e $0,79 \mathrm{~kg}$.fenol. $\mathrm{m}^{-3} \cdot \mathrm{dia}^{-1}$, para concentrações de fenol correspondentes entre 52 a $518 \mathrm{mg} . \mathrm{L}^{-1}$. Os resultados de eficiência de remoção foram satisfatórios, quando comparados a trabalhos realizados por outros autores. A Tabela 5.2 mostra, de maneira simplificada trabalhos realizados recentemente. 


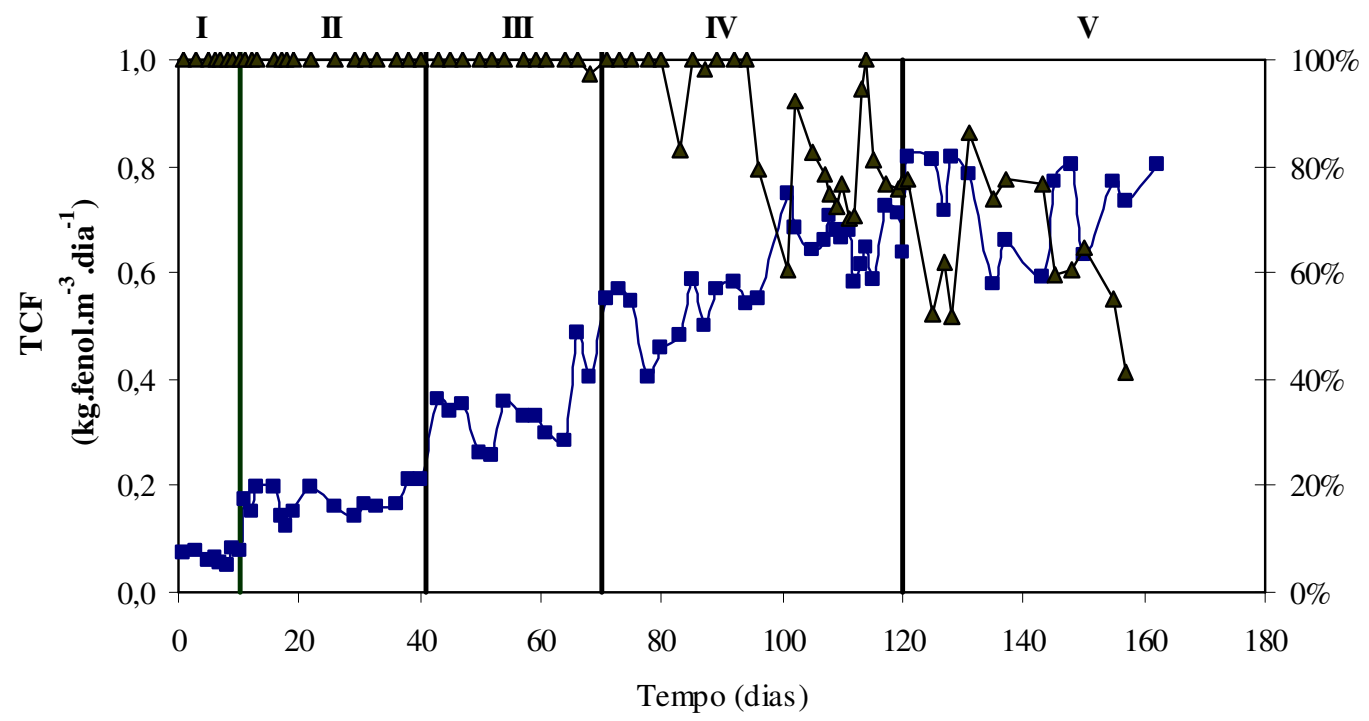

Figura 5.5 - Variação da TCF (ロ) e eficiência de redução de fenol ( $\boldsymbol{\Delta}$ ).

Tabela 5.2 - Descrição das principais características de estudos na degradação do fenol em reatores de leito fluidificado.

\begin{tabular}{|c|c|c|c|c|}
\hline Autores & Sistema & $\begin{array}{c}\text { fenol } \\
\left(\mathrm{mg} \cdot \mathrm{L}^{-1}\right)\end{array}$ & $\begin{array}{c}\mathrm{TCF}_{\text {aplicada }} \\
\left(\mathrm{kg} \cdot \mathrm{fenol} \cdot \mathrm{m}^{-3} \cdot \mathrm{dia}^{-1}\right)\end{array}$ & $\mathrm{TDH}$ \\
\hline Sancinetti (2004) & RALF & $50-500$ & $0,09-0,9$ & $24 \mathrm{~h}(213,3 \mathrm{~h})$ \\
\hline $\operatorname{Sader}^{1}(2005)$ & RALF & $100-400$ & $0,14-0,41$ & $24 \mathrm{~h}(222 \mathrm{~h})$ \\
\hline Amorim (2007) & RALF & $50-700$ & $0,09-1,29$ & $24 \mathrm{~h}(214 \mathrm{~h})$ \\
\hline Atual & RALF & $52-518$ & $0,07-0,79$ & $24 \mathrm{~h}(216)$ \\
\hline
\end{tabular}

1 - Considerando apenas os resultados obtidos com RALF preenchido com poliestireno;

2 - TDH considerando volume útil reacional.

Sancinetti (2004) aplicou praticamente a mesma taxa de carregamento de fenol, e obteve eficiências de remoção de fenol de $100 \%$, até as concentrações de $200 \mathrm{mg} \cdot \mathrm{L}^{-1}$ e de $97 \%$ para concentrações de $300 \mathrm{mg} \cdot \mathrm{L}^{-1}$. Contudo, em função de problemas operacionais durante esta fase, o sistema teve que ser aberto e esvaziado, causando sérios problemas no reator e reduzindo a eficiência média para esta concentração para $86 \%$, resultado inferior às eficiências obtidas neste trabalho. 
No entanto, para concentrações em torno de $400 \mathrm{mg} . \mathrm{L}^{-1}$, os resultados de eficiências obtidos por Sancinetti (2004) foram de praticamente 100\%, resultado superior ao encontrado neste trabalho (79\%) para esta concentração. Esta constatação pode ser atribuída ao fato de que, diante dos problemas operacionais e da perda de estabilidade do sistema, a autora optou por reduzir as taxa de carregamento e realizar modificações na composição da água residuária, visando recuperação do sistema, operações estas não realizadas neste trabalho. Para cargas limites de 0,9 kg.fenol. $\mathrm{m}^{-3} \cdot \mathrm{dia}^{-1}$, houve decaimento nos valores de eficiência, mas a autora comenta que necessitaria de um tempo maior de operação com a TCF aplicada máxima para afirmar com maior precisão a capacidade do sistema para realizar o tratamento.

Nos testes em batelada realizados por Eiroa et al. (2005), houve remoção completa do fenol com concentrações variando entre 30 e $180 \mathrm{mg} . \mathrm{L}^{-1}$, tanto com a presença quanto na ausência de formaldeído. Com concentrações de $360 \mathrm{mg} \cdot \mathrm{L}^{-1}$ mesmo, após 36 dias de tratamento, a eficiência foi de apenas 33,7\%. Com concentrações de $580 \mathrm{mg} . \mathrm{L}^{-1}$, a remoção foi completamente inibida. Os autores comentam que se a biomassa tivesse sido adaptada ao fenol previamente, provavelmente as concentrações limites de tratamento seriam mais altas.

Os autores utilizaram o lodo adaptado ao fenol nos ensaios em batelada, para realizar testes em um reator UASB, atingindo concentrações de fenol afluente de até $1010 \mathrm{mg} . \mathrm{L}^{-1}$. Quando a concentração foi igual a $755 \mathrm{mg} . \mathrm{L}^{-1}$, a remoção ficou em torno 90,6\%, com taxas de carregamento correspondentes a 0,03 e 1,0 g DQO $\left(\mathrm{C}_{6} \mathrm{H}_{6} \mathrm{O}\right) \cdot \mathrm{L}^{-1} \cdot \underline{\mathrm{d}}^{-1}$. Quando a concentração afluente foi incrementada pra $1010 \mathrm{mg} . \mathrm{L}^{-1}$, a concentração efluente chegou a $650 \mathrm{mg} . \mathrm{L}^{-1}$, evidenciando que esta concentração de fenol causou inibição ao tratamento. Os autores então, optaram por reduzir a concentração de fenol para $505 \mathrm{mg} . \mathrm{L}^{-1}$ e acrescentar formaldeído, de forma que o sistema se recuperou em poucos dias, reduzindo satisfatoriamente as concentrações de fenol no efluente. 
Desta forma, pode-se observar que, mesmo empregando um inóculo adaptado e um reator reconhecidamente hábil para o tratamento de fenol, o limite da concentração para um tratamento com êxito foi de $755 \mathrm{mg} . \mathrm{L}^{-1}$. Para concentrações de fenol superiores a $1000 \mathrm{mg} . \mathrm{L}^{-}$ ${ }^{1}$, o tratamento foi inibido, tendo que retornar para aplicações de concentrações mais baixas, evidenciando assim a toxicidade deste composto aromático.

Embora o principal objetivo do trabalho realizado por Sader (2005) não tenha sido avaliar a taxa de carregamento máxima que os três sistemas avaliados poderiam suportar, ao se comparar a faixa de variação de TCF aplicada no reator anaeróbio de leito fluidificado, onde foi empregado poliestireno como meio suporte $\left(0,14-0,41 \mathrm{~kg} \cdot \mathrm{fenol} \cdot \mathrm{m}^{-3} \cdot \mathrm{dia}^{-1}\right)$, os resultados de eficiências de remoção de fenol foram inferiores aos obtidos neste trabalho.

Esta constatação pode ser atribuída, principalmente, às modificações realizadas por Amorim (2007), no tocante à adaptação do inóculo à água residuária, além da ampliação da escala. $\mathrm{O}$ autor realizou inoculação e adaptação concomitante no próprio reator (procedimento igualmente empregado neste trabalho), com TCF aplicada variando entre 0,09 - 1,29 kg.fenol.m ${ }^{-3} \cdot \mathrm{dia}^{-1}$. Para taxas de carregamento de até $0,67 \mathrm{~kg} \cdot \mathrm{fenol} \cdot \mathrm{m}^{-3} \cdot \mathrm{dia}^{-1}$, os resultados, em termos de eficiência, foram praticamente iguais aos obtidos neste trabalho. No entanto, para TCFs aplicadas maiores que 0,67 kg.fenol. $\mathrm{m}^{-3} \cdot \mathrm{dia}^{-1}$, os resultados de eficiências encontrados nesta pesquisa foram inferiores aos do autor supracitado.

Além da comprovada toxicidade do fenol (FANG; CHAN, 1997), a depender das concentrações de fenol e da capacidade de depuração do corpo receptor, a presença de fenol também implica em consumo de oxigênio, provocando maior impacto ambiental, por desfavorecer espécies aquáticas mais exigentes com concentrações de $\mathrm{O}_{2}$. Teoricamente, o fenol consome 2,38 mol. $\mathrm{O}_{2}$ por mol. $\mathrm{C}_{6} \mathrm{H}_{5} \mathrm{OH}$. No entanto, os valores de DQO encontrados neste trabalho foram superiores em função da composição da água residuária, que recebeu adição de 0,5 g de extrato de levedura por litro de água residuária preparada. Essa 
concentração (que permaneceu constante durante todo trabalho) provocou um acréscimo no sistema de 600 mg.DQO.L ${ }^{-1}$. A Figura 5.6 mostra os valores de DQO afluente, efluente e de eficiência de redução.

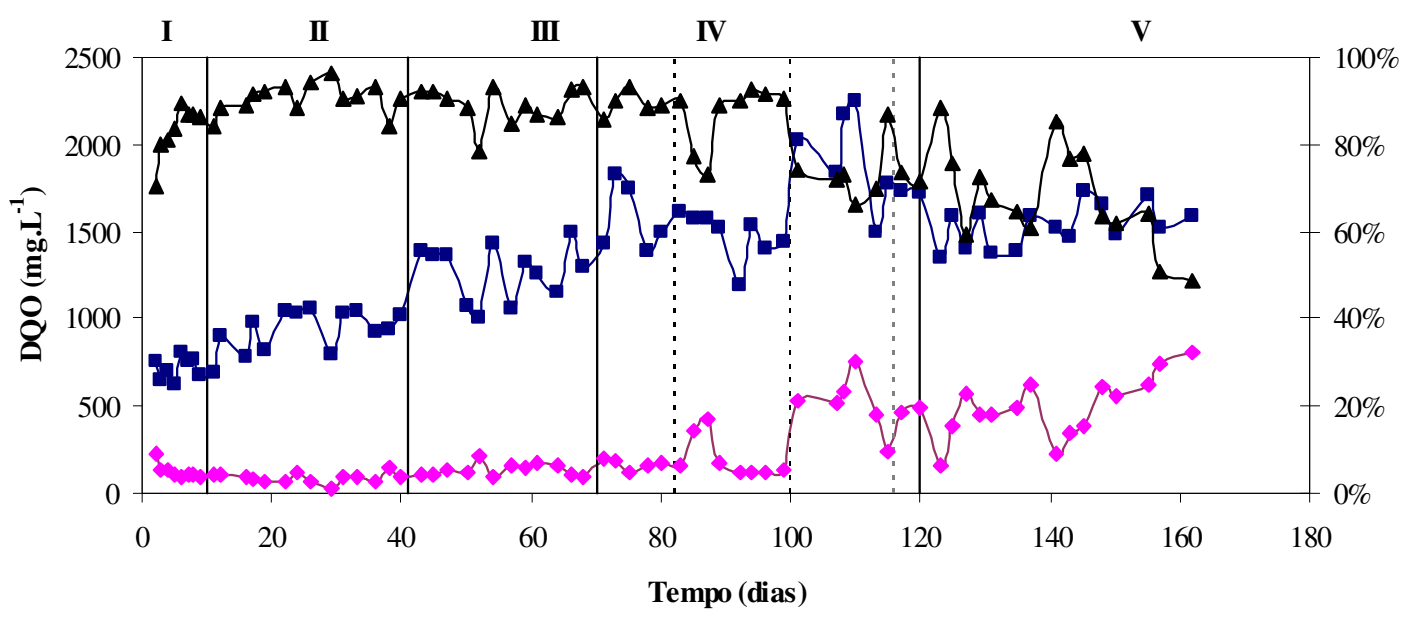

Figura 5.6 - Variação temporal das concentrações de DQO afluente (๘), efluente ( $)$, eficiência de redução de $\operatorname{DQO}(\boldsymbol{\Lambda})$, mudanças de fases (-) e dias de realização de limpeza e manutenção do reator $(\cdots)$.

Embora as concentrações de fenol na fase 5 tenham aumentado, o valor médio afluente de DQO foi inferior ao da transição da fase 4 para 5. Isso ocorreu em função da utilização de um novo frasco de extrato de levedura, que, embora tenha sido da mesma marca e com a mesma concentração daquele que estava sendo utilizado até então, apresentou contribuição em torno de $500 \mathrm{mg} . \mathrm{L}^{-1}$, ou seja, $100 \mathrm{mg} . \mathrm{L}^{-1}$ a menos que o anterior. Assim, considerando a precisão do método, o fato de que o acréscimo da concentração de fenol em relação à fase de transição não tenha sido substancial e os desvios padrões para cada fase, os resultados se mostram coerentes.

Seguramente, pode-se afirmar que os valores de DQO são correlacionados com as concentrações de fenol, de maneira que, quando há diminuição da remoção de fenol, há igualmente diminuição na redução da DQO. Os valores médios, desvios padrão de DQO afluente e das respectivas eficiências de redução estão apresentados na Tabela 5.3. 
Tabela 5.3 - Valores médios de DQO e de eficiência de redução, conforme as mudanças de fase.

\begin{tabular}{cccc}
\hline Fase & Fenol $\left(\mathrm{mg} . \mathrm{L}^{-1}\right)$ & DQO total afluente & Eficiência de redução (\%) \\
\hline I & 52 & $715 \pm 64$ & $83 \pm 6$ \\
II & 107 & $926 \pm 108$ & $92 \pm 3$ \\
III & 201 & $1240 \pm 157$ & $88 \pm 4$ \\
IV & 335 & $1519 \pm 161$ & $88 \pm 6$ \\
Transição IV-V & 429 & $1873 \pm 253$ & $73 \pm 6$ \\
V & 518 & $1529 \pm 121$ & $68 \pm 11$ \\
\hline
\end{tabular}

A determinação de DQO é igualmente importante porque raramente os estudos são realizados com uma única fonte de carbono. Desta forma, é corriqueira a utilização não só de extrato de levedura, mas também de outros co-substratos como, por exemplo, metanol (ZHU et al., 2006), sacarose (FANG; ZHOU, 1999) entre outros.

\subsection{DESNITRIFICAÇÃO}

Considerando que $1 \mathrm{~g}$ de $\mathrm{N}-\mathrm{NO}_{3}$ requer 2,86 g de DQO, torna-se coerente a comparação com trabalhos que avaliaram remoção de fenol sob condições desnitrificantes, independente da composição da água residuária.

Em função da concentração do extrato de levedura ter sido mantida constante durante todo o experimento, apesar do aumento de concentração de fenol em cada fase, a relação $\mathrm{DQO} / \mathrm{N}-\mathrm{NO}_{3}$ foi diminuindo gradativamente, como pode ser observado na Tabela 5.4, que também apresenta os valores das concentrações médias de $\mathrm{N}-\mathrm{NO}_{3}$, as relações entre carbono e nitrogênio, $\mathrm{DQO} / \mathrm{N}-\mathrm{NO}_{3}$ e as eficiências de remoção para cada fase de operação do sistema. 
Tabela 5.4 - Valores médios das concentrações de $\mathrm{N}$ - $\mathrm{NO}_{3}$, eficiência de redução de nitrogênio, relação $\mathrm{C} / \mathrm{N}-\mathrm{NO}_{3}$ e DQO/N - $\mathrm{NO}_{3}$, conforme as mudanças de fases.

\begin{tabular}{ccccc}
\hline Fase & $\begin{array}{c}\mathrm{N}-\mathrm{NO}_{3} \\
\left(\mathrm{mg} . \mathrm{L}^{-1}\right)\end{array}$ & Eficiência de remoção $(\%)$ & $* \mathrm{C} / \mathrm{N}$ & $* * \mathrm{DQO} / \mathrm{N}-\mathrm{NO}_{3}$ \\
\hline I & 45 & 94 & 0,9 & 15,9 \\
II & 79 & 89 & 1,0 & 11,7 \\
III & 157 & 86 & 1,0 & 7,9 \\
IV & 260 & 79 & 1,0 & 5,8 \\
Transição IV-V & 323 & 63 & 1,0 & 5,8 \\
V & 362 & 51 & 1,1 & 4,2 \\
\hline
\end{tabular}

* C - Carbono considerando apenas a contribuição de $\mathrm{C}_{6} \mathrm{H}_{5} \mathrm{OH}$;

** DQO medida no afluente considerando a composição da água residuária total.

A Figura 5.7 mostra o comportamento da eficiência de remoção de nitrogênio, além das concentrações afluente e efluente. A queda de eficiência de remoção de fenol em decorrência dos problemas operacionais já citados, aliado ao aumento das concentrações de fenol, afetou significativamente as remoções de $\mathrm{N}^{-\mathrm{NO}_{3}}$. No entanto, para o nitrogênio, a perda de eficiência de remoção foi maior do que para o fenol. Para taxa de carregamento máxima de fenol, a eficiência média de remoção decresceu para aproximadamente 70\%. A Tabela 5.5 mostra trabalhos recentes que realizaram remoção de fenol sob condições desnitrificantes. 


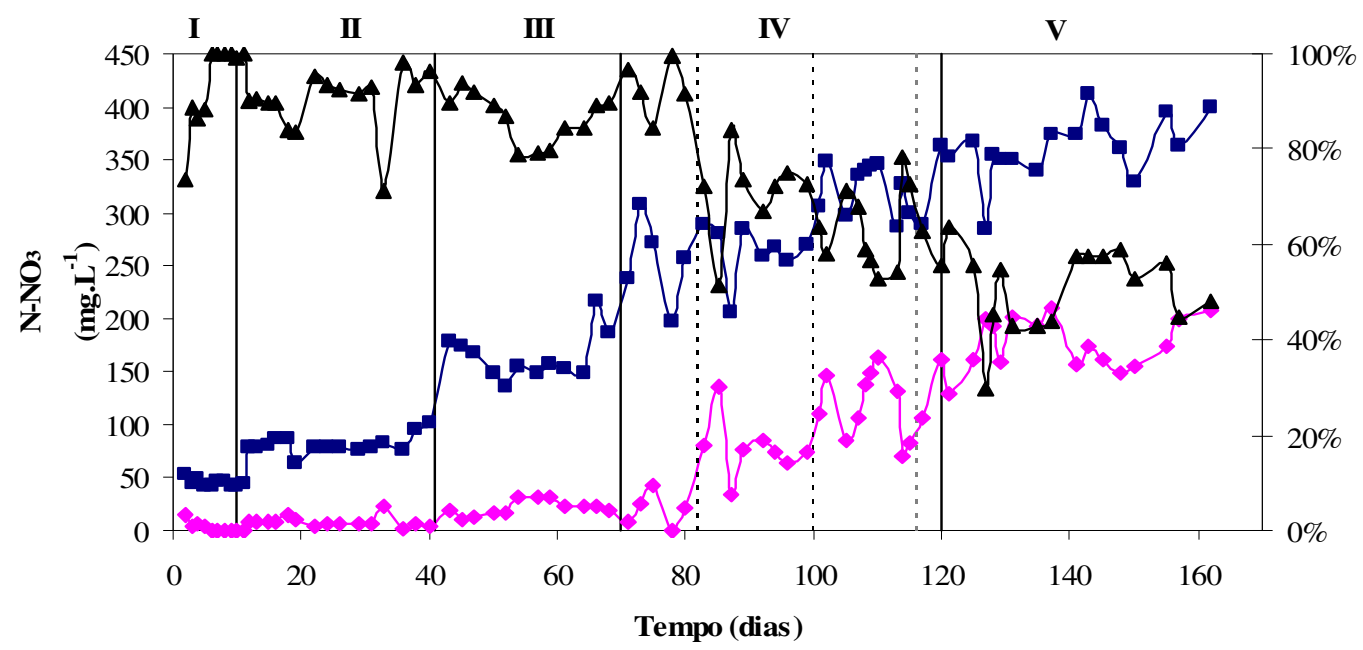

Figura 5.7 - Variação temporal das concentrações de nitrato afluente (๘), efluente ( $\bullet$ ), eficiência de remoção ( $\mathbf{\Delta})$, mudanças de fases (-) e dias de realização de limpeza e manutenção do reator (--").

Tabela 5.5 - Pesquisas envolvidas na degradação do fenol, utilizando $\mathrm{NO}_{3}$ como aceptor final de elétrons.

\begin{tabular}{ccccc}
\hline Autores & Reator & Fenol (mg.L $\left.{ }^{-1}\right)$ & $\begin{array}{c}\mathrm{TCF} \\
\left(\mathrm{kg} . f e n o l . \mathrm{m}^{-3} \cdot \mathrm{dia}^{-1}\right)\end{array}$ & DQO/N - $\mathrm{NO}_{3}$ \\
\hline Fang e Zhou (1999) & UASB & 200 & 0,2 & $2,86-5,23$ \\
Sarfaraz et al. (2004) & SBR & $550-1150$ & $2,3-4,6$ & $* 3,40$ \\
Zhu et al. (2006) & UASB & $200-600$ & $0,07-0,768$ & $3,31-6,0$ \\
Atual & RALF & $51,7-493,3$ & $0,07-0,79$ & $* 3,50$ \\
\hline
\end{tabular}

* Valor médio afluente considerando apenas DQO gerada pelo fenol, em função do extrato de levedura ser altamente biodegradável.

A taxa de carregamento de nitrogênio variou entre 0,05 e $0,5 \mathrm{~kg} \cdot \mathrm{N}-\mathrm{NO}_{3} \cdot \mathrm{m}^{-3} \cdot \mathrm{dia}^{-1}$. A média de eficiência de remoção de nitrogênio reduziu-se de 94\% (taxa de carregamento mínima) para apenas $51 \%$ (taxa de carregamento máxima). A Figura 5.8 mostra a taxa de carregamento de $\mathrm{N}-\mathrm{NO}_{3}$ em função do tempo de operação do sistema. 


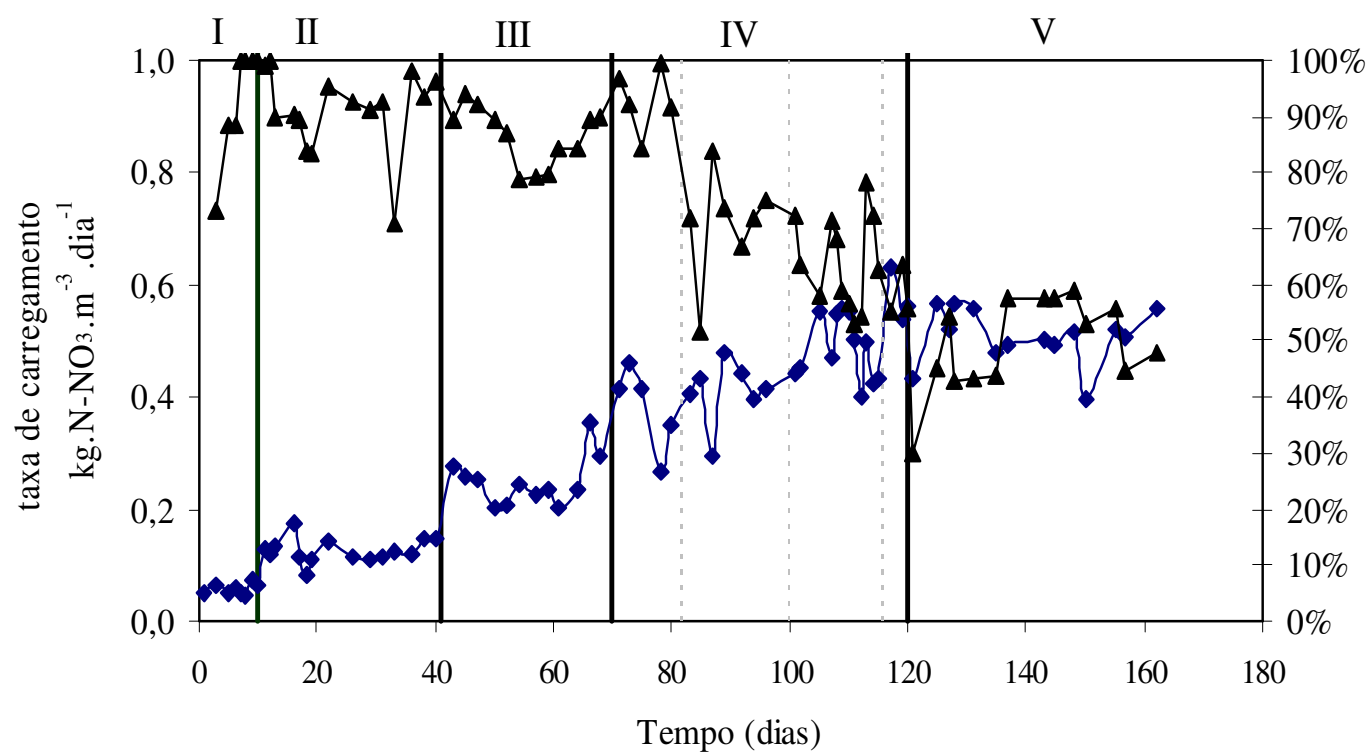

Figura 5.8 - Variação temporal da taxa de carregamento de nitrogênio aplicada afluente ( $\boldsymbol{\square})$, eficiência de remoção $(\mathbf{\Lambda})$, mudanças de fases ( - ) e dias de realização de limpeza e manutenção do reator ("*).

Lakshmi e Setty (2007) constataram que houve incremento da espessura do biofilme para taxa de carregamento de nitrogênio de até $15 \mathrm{~kg} \cdot \mathrm{m}^{-3}$. À medida que a taxa de carregamento atingiu o nível máximo $25 \mathrm{~kg} \cdot \mathrm{m}^{-3}$, houve diminuição contínua da espessura do biofilme. Os autores atribuem esse decréscimo da atividade da biomassa aos efeitos deletérios da presença de altas concentrações de nitrogênio, que implicou em redução do consumo de substrato, causando decréscimo da concentração de biomassa e conseqüentemente diminuição da espessura do biofilme.

Fang e Zhou (1999) variaram a relação DQO/ N-NO 3 entre 2,86 a 5,23 e observaram que a transferência de elétrons para desnitrificação e metanogênese dependia da relação DQO/ $\mathrm{N}-\mathrm{NO}_{3}$. Quando a relação foi igual a 3,34, os elétrons foram totalmente utilizados pela desnitrificação, fato constatado diante de ter sido cessada a produção de metano no reator UASB, quando operado sob essas condições. Quando a relação foi de 5,23, o sistema conseguiu degradar completamente as concentrações de fenol. No entanto a cultura foi inábil para degradação completa do $m$ - cresol. Os autores afirmam ainda que, para valores inferiores a 3,34, a metanogênese cessa dando lugar à desnitrificação incompleta. 
Periodicamente, por meio de medidor de gás, foram coletadas amostras do biogás e posteriormente injetadas no cromatográfico, para verificar se estava ocorrendo produção de metano. Como o valor da relação $\mathrm{DQO} / \mathrm{N}-\mathrm{NO}_{3}$ observada neste trabalho foi suficientemente semelhante a do trabalho realizado por Fang e Zhou (1999) justifica-se então, o fato de nunca ter sido detectada presença do gás metano, durante todo período de operação do sistema.

No entanto, depois dos testes realizados por Santos (2003), com três fontes de carbono (etanol, metanol e gás metano) e diferentes relações carbono - nitrogênio, a autora recomenda cautela com relação a este parâmetro. Isto porque foi observado que, mesmo testando relações idênticas $(\mathrm{C} / \mathrm{N}=1)$ para os compostos etanol e metanol, o primeiro encontrava-se em excesso para realização da desnitrificação. Esta constatação pode ser atribuída ao fato de que o etanol possui dois carbonos, podendo assim, doar mais elétrons que o metanol. Assim, a autora recomenda que, se for possível estabelecer um doador de elétrons específico, que anteriormente seja avaliada a capacidade do composto em doar elétrons, para que só então, seja determinada a quantidade de doador de elétrons a ser introduzida. Ou seja, a determinação arbitrária de uma relação pode trazer resultados indesejáveis.

Sarfaraz et al. (2004), através da operação de um SBR, obtiveram eficiência superior a $80 \%$, com taxas de carregamento consideravelmente elevadas, variando entre $2,3-4,6$ kg.fenol.m ${ }^{-3} \cdot \mathrm{dia}^{-1}$. Provavelmente, o alto desempenho do sistema foi em função do lodo e do processo de adaptação empregado. O inóculo foi proveniente de uma unidade de tratamento de efluentes de indústria de coqueria. Como o fenol é responsável por cerca $80 \%$ da DQO afluente nesse tipo de indústria, e como relativamente há considerável presença de nitrogênio, os microrganismos possivelmente estavam mais adaptados para remoção desses compostos. Além disso, o tempo de adaptação adotado por estes autores foi muito maior (6 semanas) quando comparada ao período deste trabalho (14 dias). Um outro fator que pode ter 
contribuído foi a quantidade de extrato de levedura na composição da água residuária. $\mathrm{O}$ autor utilizou o dobro da concentração empregada neste trabalho.

Hwang et al. (2006), após 30 dias do início da operação do sistema, aumentaram a taxa de carregamento de nitrato afluente de 0,7 para $1,5 \mathrm{~kg} . d i a^{-1}$, o que resultou em decréscimo na eficiência de redução de nitrogênio. Entre os dias 34 a 59, a concentração foi

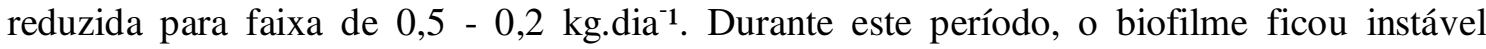
havendo flotação para a o topo do reator. Isto fez com que fossem necessárias duas limpezas, com paralisações na operação nos dias 50 - 51 e 53 - 56 para remoção da biomassa flotada.

A transição da fase 3 para fase 4 do trabalho realizado por Zhou et al. (2006), e a transição da fase 4 para fase 5 deste trabalho, proporcionaram rápido acúmulo de fenol e de $\mathrm{N}-\mathrm{NO}_{3}$ no efluente. Os autores atribuíram esse incremento substancial de fenol $\mathrm{N}-\mathrm{NO}_{3}$ no efluente ao aumento da taxa de carregamento, que inibiu fortemente a habilidade dos microrganismos para remoção desses compostos.

Vale ressaltar que, embora semelhantes às concentrações de fenol afluente e a relação $\mathrm{DQO} / \mathrm{N}-\mathrm{NO}_{3}$, as cargas aplicadas pelos autores foram inferiores (em função do TDH), no entanto, a perda de eficiência foi maior que a deste trabalho. Em contrapartida, após 20 dias, a eficiência de remoção de fenol do sistema proposto pelos autores atingiu $100 \%$, enquanto para o mesmo tempo de operação, o RALF apresentou eficiência média de 79\%, provavelmente em função dos problemas operacionais ocorridos durante este período.

Embora no final da quinta fase $\left(155^{\circ}\right.$ dia $)$ o sistema tenha apresentado concentrações de até $10 \mathrm{mg} . \mathrm{L}^{-1}$ de $\mathrm{N}-\mathrm{NO}_{2}$ no efluente, até então não havia sido detectado acúmulo de nitrito no sistema, resultados semelhantes aos trabalhos supracitados. Durante a maior parte de tempo de operação do reator, a concentração de $\mathrm{N}-\mathrm{NO}_{2}$ no efluente não passou de $5 \mathrm{mg} . \mathrm{L}^{-1}$, com concentração média de $1,5 \mathrm{mg} \cdot \mathrm{L}^{-1}$. 
Pode-se observar na Figura 5.9 que, após o efluente apresentar o valor máximo da concentração de nitrito, houve uma tendência de retorno para concentração média observada durante a operação do sistema. No entanto, o período de operação após esta ocorrência não foi suficientemente longo para afirmar que não haveria acúmulo permanente de nitrito, principalmente em se tratando de um sistema biológico anaeróbio, onde as reações são mais lentas do que os sistemas aeróbios, por exemplo.

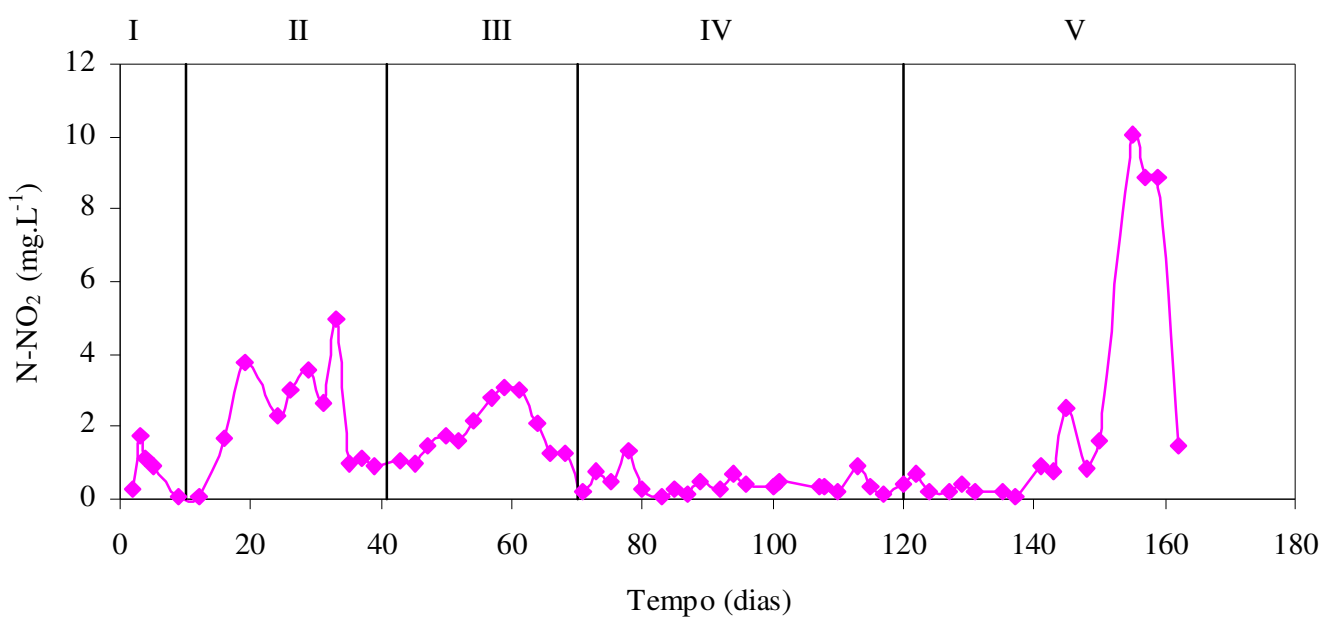

Figura 5.9 - Variação temporal das concentrações $\mathrm{N}$ - $\mathrm{NO}_{2}$ do efluente (४).

Anthonisen et al. (1976) apud Dombroski (2003) comentaram que pode haver diminuição da atividade das bactérias Nitrobacter sp. devido à presença de ácido nitroso não ionizado que provoca inibição desses microrganismos em concentrações baixas situadas entre 0,22 e 2,8 mg. $\mathrm{L}^{-1}$, ou devido à presença de amônia livre $\left(0,1\right.$ a $\left.1 \mathrm{mg} \cdot \mathrm{L}^{-1}\right)$ no sistema. Ao realizarem testes com diferentes tempos de retenção celular, os pesquisadores verificaram que para o tempo mínimo testado (20 dias) o sistema apresentou concentrações máximas de nitrito no efluente flutuando entre 4 e $12 \mathrm{mg} . \mathrm{L}^{-1}$.

Eiroa et al. (2005) comentaram que não houve acúmulo de nitrito nos testes realizados em batelada, seja empregando o fenol e/ou formaldeído como fonte de carbono e energia, exceto quando as concentrações de fenol excederam $580 \mathrm{mg} . \mathrm{L}^{-1}$. Neste momento, as 
concentrações de nitrito medidas no efluente foram de $12,2 \mathrm{mg} \cdot \mathrm{L}^{-1}$, valores muito semelhantes ao encontrados neste trabalho.

\subsection{DEMAIS PARAMETROS MONITORADOS}

Sistemas anaeróbios são altamente dependentes dos valores de $\mathrm{pH}$, de maneira que são tipicamente mantidos no limite superior para metanogênese, a fim de prevenir o crescimento de microrganismos acidogênicos, os quais podem provocar altas concentrações

de ácidos voláteis no sistema. Assim, é essencial que o reator possua capacidade de neutralizar eventual acúmulo de ácidos (RAJESHWARI; GUPTA, 2006).

No caso dos microrganismos desnitrificantes a sensibilidade não é tão acentuada. No entanto, valores de $\mathrm{pH}$ fora da faixa ótima (entre 7 - 8) podem provocar o acúmulo de compostos intermediários, que desfavorecem o processo (RITTMANN; MCCARTY, 2001).

Os valores de $\mathrm{pH}$ do afluente se apresentaram levemente ácidos e estiveram situados na faixa entre 5,68 a 6,72. No entanto, esses valores foram acrescidos pelo próprio sistema (demonstrando que o sistema teve capacidade de tamponamento) que apresentou faixa de variação para efluente entre 7,64 a 8,35, não havendo necessidade de correção com alcalinizantes. A Figura 5.10 mostra a variação de pH para afluente e efluente. 


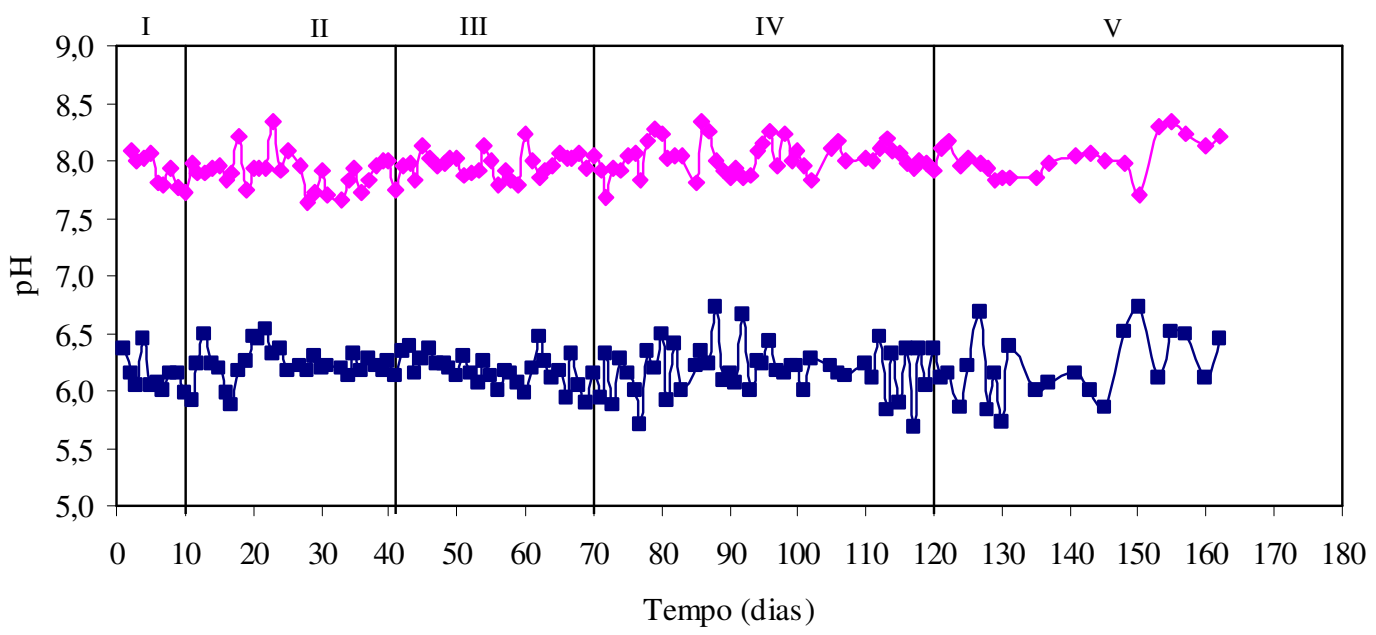

Figura 5.10 - Variação temporal do pH, afluente (๘) e efluente ( $\bullet$ ).

Os valores estão plenamente de acordo com trabalho realizado por Chen e Lin (1993), que afirmam que a faixa ótima de pH está entre 7,0 - 8,0 para desnitrificação para temperaturas compreendidas entre $30^{\circ} \mathrm{C}$ e $35^{\circ} \mathrm{C}$.

Hwang et al. (2006) comentaram que, após 40 dias de operação do reator RALF submetido a condições desnitrificantes, o pH esteve com valor situado em torno de 8 sendo elevado para 9. Os autores optaram por reduzir o $\mathrm{pH}$ para 8,5 com $\mathrm{K}_{2} \mathrm{CO}_{3}$ para precipitar o cálcio. Em seguida foi feita uma carbonatação com $\mathrm{CO}_{2}$ para reduzir o pH para 6,5. $\mathrm{O}$ objetivo deste procedimento foi evitar interferências na disponibilidade de nutrientes fundamentais para os microrganismos, a exemplo do fósforo.

O fósforo na água apresenta-se principalmente nas seguintes formas: ortofosfatos, polifosfatos e fósforo orgânico. A importância do fósforo associa-se principalmente ao fato de que é um nutriente essencial para o crescimento dos microrganismos responsáveis pela estabilização da matéria orgânica. A solubilidade das formas do fósforo é governada principalmente pelos valores do $\mathrm{pH}$ da solução. A exemplo do $\mathrm{H}_{2} \mathrm{PO}_{4}{ }^{-}$, verifica-se que a concentração máxima desta forma iônica é encontrada entre os valores de $\mathrm{pH}$ ácido situados entre 3 e 6. 
Vale ressaltar que neste presente trabalho não houve correção de $\mathrm{pH}$, de forma que cerca de $60 \%$ dos valores de $\mathrm{pH}$ medidos no efluente foram superiores a 8,0 , e que a redução da eficiência de remoção de nitrogênio e fenol, pode estar associada ao comprometimento da concentração de fósforo na água residuária.

O aumento progressivo das concentrações de fenol e nitrato não afetou, de maneira significativa, os valores de $\mathrm{pH}$ no efluente. Em contrapartida, os valores da alcalinidade aumentaram conforme as mudanças de fase. Serão apresentados apenas, dados referentes a alcalinidade a bicarbonato, em detrimento desta ser a única produzida no processo de desnitrificação. A Figura 5.11 exibe a variação temporal das concentrações de alcalinidade bicarbonato para amostras afluente e efluente.

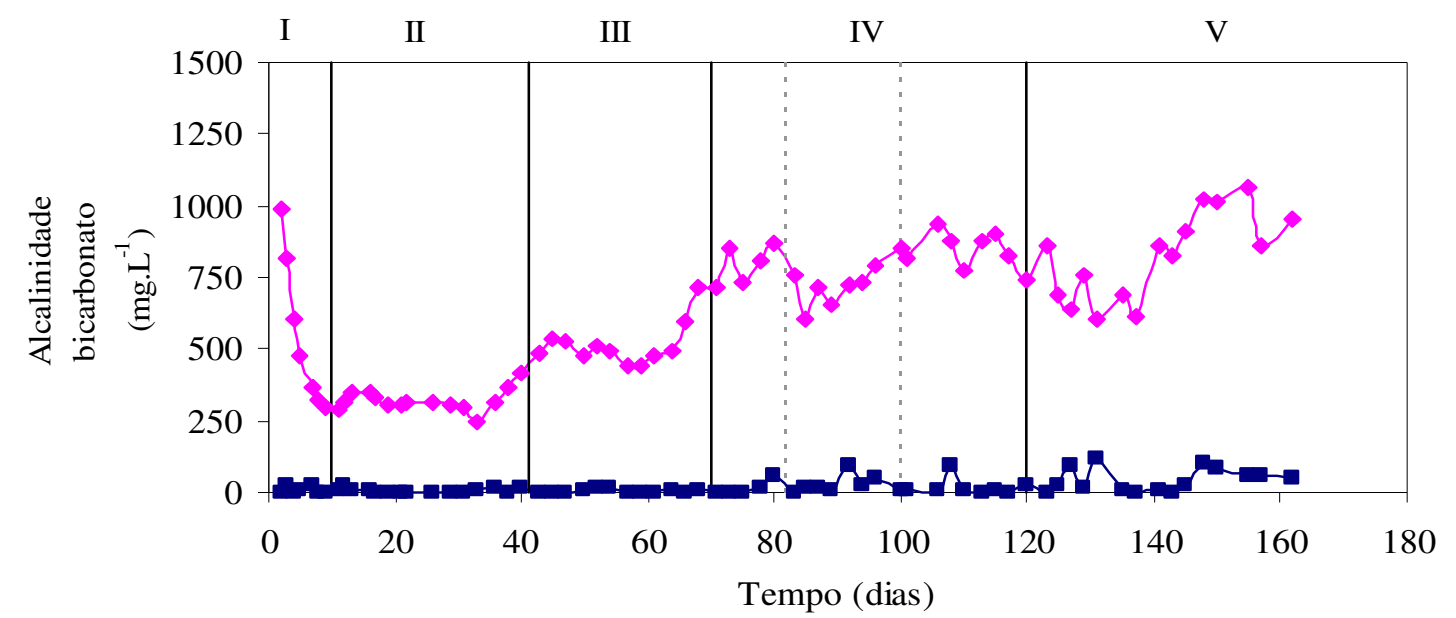

Figura 5.11 - Variação das concentrações de alcalinidade afluente (๘), efluente (»), mudanças de fases $(-)$ e dias de realização de limpeza e manutenção do reator ("*).

Após a partida do reator durante a primeira fase, houve decaimento nos valores das concentrações de alcalinidade bicarbonato (reduziu de 948 para $298 \mathrm{mg} \cdot \mathrm{CaCO}_{3} \mathrm{~L}^{-1}$ ), em função de o sistema ter estado em recirculação durante a fase de adaptação, período em que deve ter havido acúmulo das hidroxilas liberadas durante a degradação do fenol. Além disto, a 
desnitrificação também gera aumento de alcalinidade, cada mol de nitrato libera 1 mol de hidroxila (ou acréscimo de 3,57 mg.CaCO $3 . \mathrm{L}^{-1}$ por mg de $\mathrm{N}-\mathrm{NO}_{3}$ ).

Santos (2003) também verificou valores elevados de alcalinidade a bicarbonato durante a partida dos reatores estudados. A autora atribuiu este fato ao provável crescimento de organismos metanogênicos (já que o inóculo era de lodo metanogênico), que utilizam os produtos intermediários das bactérias metanotróficas, a exemplo do metanol e do ácido acético. Assim, como ainda havia o processo de adaptação da cultura desnitrificante pode ter havido vantagem competitiva dos organismos metanogênicos, de forma que houve geração de alcalinidade no sistema.

Durante a operação do sistema e sob condições estritamente metanogênicas, os valores de alcalinidade a bicarbonato, para efluentes advindos do tratamento do fenol, são praticamente constantes, como pode ser observado no trabalho realizado por Sancinetti (2004), com valor médio de $590 \mathrm{mg} \cdot \mathrm{CaCO}_{3} \mathrm{~L}^{-1}$, e por Amorim, (2007), cuja concentração média foi de $294 \mathrm{mg} . \mathrm{CaCO}_{3} \mathrm{~L}^{-1}$, durante todo experimento.

A Tabela 5.6 mostra os valores das concentrações teóricas de alcalinidade gerada pelo fenol e pelo nitrato, além dos valores de alcalinidade média por fase efetivamente medida no efluente do reator anaeróbio de leito fluidificado. 
Tabela 5.6 - Valores teóricos de alcalinidade medidos no efluente do reator.

\begin{tabular}{|c|c|c|c|c|c|c|}
\hline Fases & $\begin{array}{l}\text { fenol } \\
\text { removido } \\
\left(\mathrm{mg}^{\left.-\mathrm{L}^{-1}\right)}\right.\end{array}$ & $\begin{array}{c}\text { alcalinidade } \\
\text { fenol } \\
\left(\mathrm{mg} . \mathrm{L}^{-1}\right)\end{array}$ & $\begin{array}{c}\mathrm{N}-\mathrm{NO}_{3} \\
\text { removido } \\
\left(\mathrm{mg} . \mathrm{L}^{-1}\right)\end{array}$ & $\begin{array}{l}\text { alcalinidade } \\
\text { nitrogênio } \\
\left(\mathrm{mg}^{-1} \mathrm{~L}^{-1}\right)\end{array}$ & $\begin{array}{l}\text { alcalinidade } \\
\text { total teórica } \\
\left(\mathrm{mg} . \mathrm{L}^{-1}\right)\end{array}$ & $\begin{array}{l}\text { alcalinidade } \\
\text { medida } \\
\left(\mathrm{mg} \cdot \mathrm{L}^{-1}\right)\end{array}$ \\
\hline I & 52 & 28 & 42 & 151 & 179 & 554 \\
\hline II & 107 & 57 & 70 & 251 & 308 & 312 \\
\hline III & 201 & 107 & 135 & 482 & 589 & 473 \\
\hline IV & 332 & 176 & 205 & 733 & 909 & 755 \\
\hline IV - V & 339 & 180 & 203 & 726 & 906 & 855 \\
\hline V & 357 & 189 & 185 & 659 & 849 & 694 \\
\hline
\end{tabular}

Pode-se observar que os valores de alcalinidade medidos são normalmente menores que os teóricos (exceto na primeira e na segunda fase). Esse fato pode ser atribuído em função de uma pequena produção de ácidos voláteis no sistema, que por sua vez consome alcalinidade. A Figura 5.12 mostra os valores de ácidos voláteis totais (AVT), para amostras afluente e efluente.

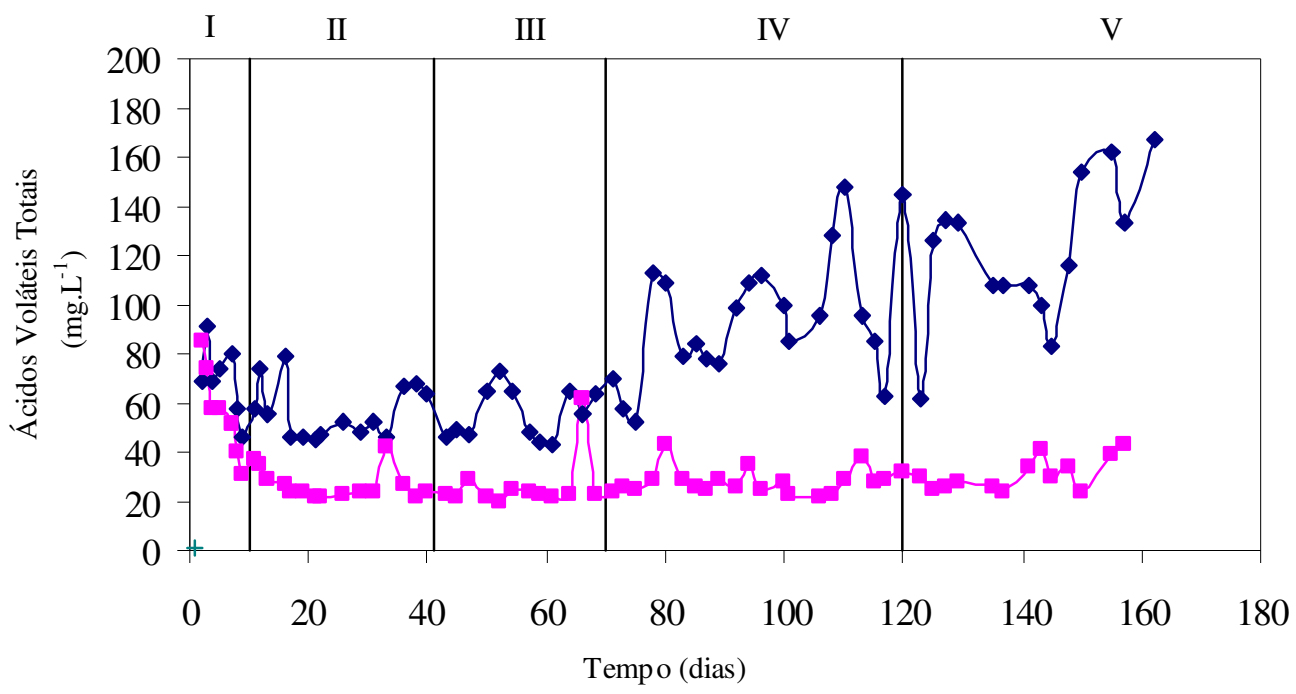

Figura 5.12 - Variação das concentrações de ácidos voláteis afluente (๘), efluente (४). 
Os valores de ácidos voláteis foram maiores para as amostras do afluente, com valor médio de $59 \mathrm{mg} . \mathrm{L}^{-1}$, para as primeiras três fases, e de $105 \mathrm{mg} . \mathrm{L}^{-1}$, para as duas últimas fases, inclusive, durante o período de transição entre estas. Esses valores apresentados para amostra afluente podem ser atribuídos a um princípio de degradação no barrilete de alimentação, já que o mesmo e o meio de cultura não foram esterilizados.

Quanto à presença de ácidos voláteis no efluente, os valores observados foram praticamente constantes durante o todo período de operação do sistema com valor médio em torno de $30 \mathrm{mg} \cdot \mathrm{L}^{-1}$.

Gusmão (2005) observou acúmulo de ácido acético no reator anaeróbio horizontal de leito fixo. A autora atribuiu esta constatação ao esgotamento do aceptor final de elétrons (nitrato), já que através dos resultados obtidos nos perfis referentes às alimentações com mxileno, etilbenzeno e BTEX, foram detectadas baixas concentrações de nitrato $\left(\mathrm{N}_{-} \mathrm{NO}_{3}{ }^{-}\right)$, no quinto ponto de amostragem do reator ( $\mathrm{L} / \mathrm{D}=20$ ), onde as concentrações desta substância foram de 6,7 mg. $\mathrm{L}^{-1}, 4,4 \mathrm{mg} \cdot \mathrm{L}^{-1}$, e $3,8 \mathrm{mg} . \mathrm{L}^{-1}$, para as alimentações com m-xileno, etilbenzeno e BTEX, respectivamente. A autora ressalta ainda que, o tempo destinado para a operação do reator, com cada um destes hidrocarbonetos, foi de cerca de 15 dias, ou seja, o tempo de operação para estas condições pode ter sido insuficiente para que as populações responsáveis pelo consumo de ácido acético se adaptassem as novas condições nos trechos finais do reator.

A escassez de aceptor final de elétrons não provocou acúmulo de ácidos neste trabalho, já que durante os primeiros 30 dias de operação (I e II fase) a eficiência média de remoção de nitrato foi de $92 \%$, com concentração média efluente de nitrogênio em torno de 6 $\operatorname{mg} \cdot L^{-1}$.

Os valores encontrados neste trabalho são semelhantes aos obtidos por Amorim (2007), onde a concentração média afluente dos AVT no RALF foi de 104 mg.L $\mathrm{L}^{-1}$, para todas 
as concentrações de fenol aplicadas (entre 50 a $700 \mathrm{mg} . \mathrm{L}^{-1}$ ). A concentração média efluente

dos AVT foi de $35 \mathrm{mg} . \mathrm{L}^{-1}$, provando que o sistema removeu os AVT, em ambos os sistemas independente do aceptor final de elétrons.

\subsection{CARACTERIZAÇÃO MORFOLÓGICA DA BIOMASSA E AVALIAÇÃO DA ADESÃO DO BIOFILME AS PARTÍCULAS DE POLIESTIRENO}

As Figuras 5.13 a 5.18 mostram imagens obtidas através da técnica de microscopia eletrônica de varredura, cujo objetivo principal é a determinação da semelhança morfológica dos microrganismos, além de observação da adesão da biomassa ao meio suporte. As imagens obtidas das Figuras 5.13 a 5.15 foram de partículas coletadas no amostrador situado a $110 \mathrm{~cm}$ da base do reator, enquanto as demais foram em pontos distintos face à realização de um perfil ao longo do comprimento do reator.

As amostras normalmente foram coletadas em períodos próximos as mudanças de fases, a fim de se avaliar as possíveis transformações pelas qual a biomassa sofreu de acordo com o tempo de operação do reator e o aumento progressivo de fenol e nitrato. 


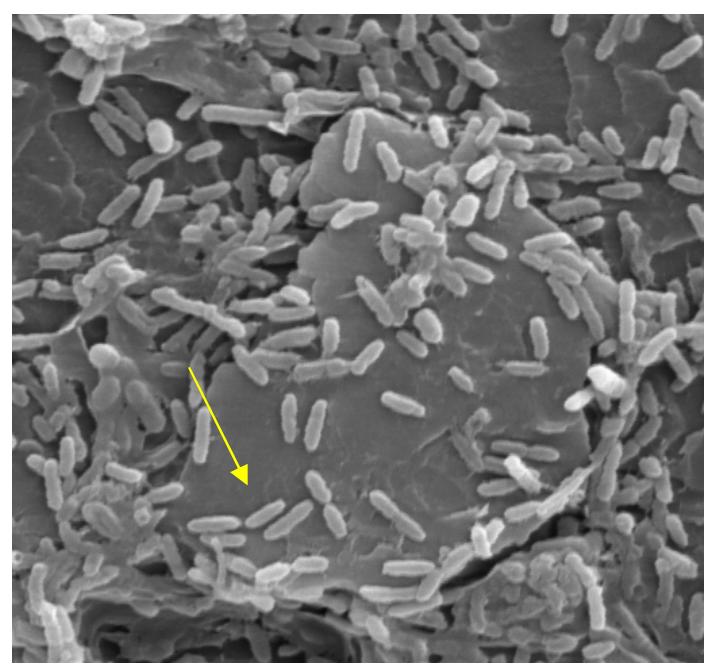

(a)

(Aumento $5000 \mathrm{x}$ )

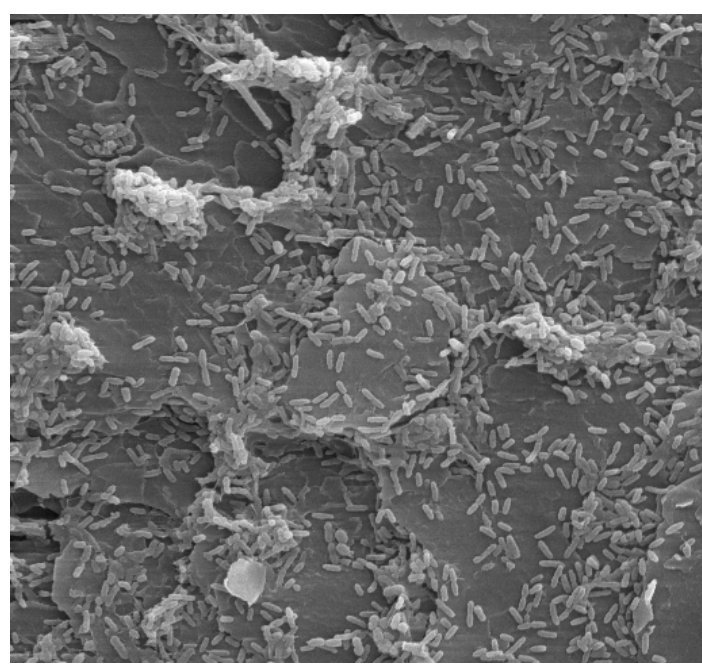

(b)

(Aumento $2000 \mathrm{x}$ )

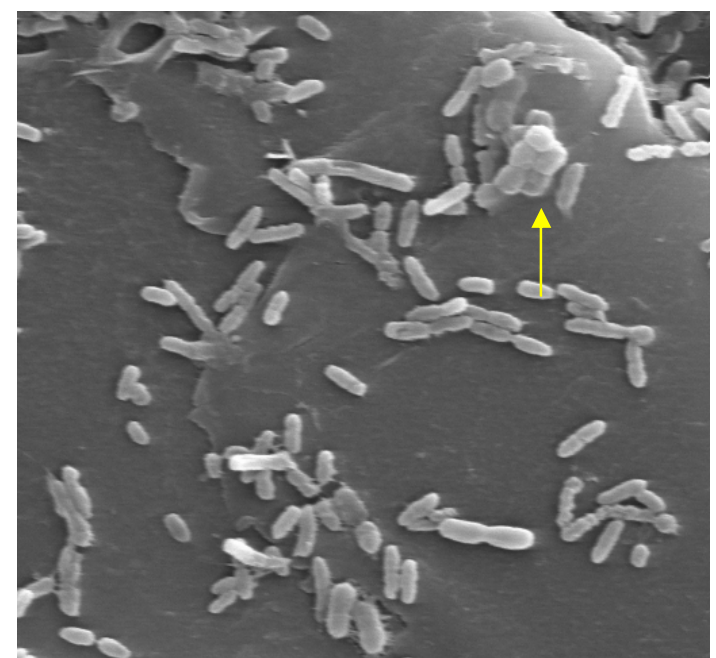

(c)

(Aumento $5000 \mathrm{x}$ )

Figura 5.13 - (a) bacilos retos; (b) imagem panorâmica mostrando biofilme bastante aderido a partícula de poliestireno; (c) cocos.

A Figura 5.13 foi obtida em exame realizado no $9^{\circ}$ dia de operação (concentração de fenol $50 \mathrm{mg} . \mathrm{L}^{-1}$ e 38 de $\mathrm{N}-\mathrm{NO}_{3}$ ), ou seja, logo após a partida do sistema.

A Figura 5.13a mostra a predominância maciça de bacilos. Embora sob curto período de adaptação e com a desvantagem do inóculo ter sido anaeróbio, a Figura 5.13b dá um 
indicativo de boa adesão da biomassa ao meio suporte. A Figura 5.13c mostra a presença de cocos, embora bem mais escassos quando comparada a população de bacilos. Este comportamento foi observado durante todo período de operação do sistema, mesmo diante das alterações das condições operacionais.

Santos (2003) observou predominância de microrganismos semelhantes às arqueas metanogênicas no lodo do inóculo. No entanto, após a adaptação e a operação dos sistemas com culturas desnitrificantes, houve alteração da morfologia dando lugar a microrganismos semelhantes a bacilos fluorescentes.

A Figura 5.14 mostra imagens obtidas ao $72^{\circ}$ dia de operação, cuja concentração média de fenol foi de $335 \mathrm{mg} . \mathrm{L}^{-1}$ e de $\mathrm{N}-\mathrm{NO}_{3}$ equivalente a $270 \mathrm{mg} . \mathrm{L}^{-1}$. Embora com concentrações de fenol e nitrato sete vezes maior do que durante o período da partida, e 86 dias após a inoculação, observa-se uma ótima aparência do biofilme. Este se encontra bastante semelhante ao início da operação mostrando que o consórcio estava bem adaptado para as mudanças nas condições operacionais.

Estas constatações só vêem a corroborar com os resultados das análises físicoquímicas realizadas no efluente durante esta fase, cuja remoção de fenol foi de aproximadamente $100 \%$ e de nitrogênio sob a forma de nitrato $80 \%$. 


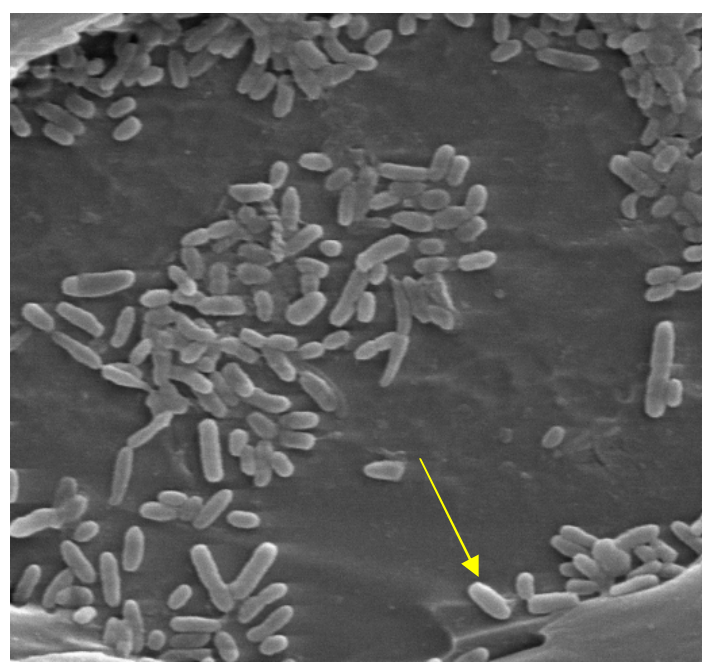

(a)

(Aumento $5000 \mathrm{x}$ )

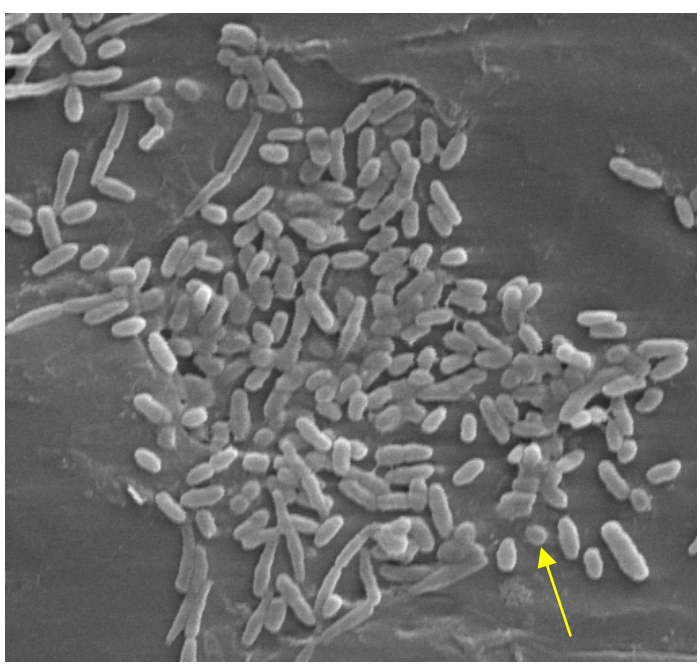

(b)

(Aumento $2000 \mathrm{x}$ )

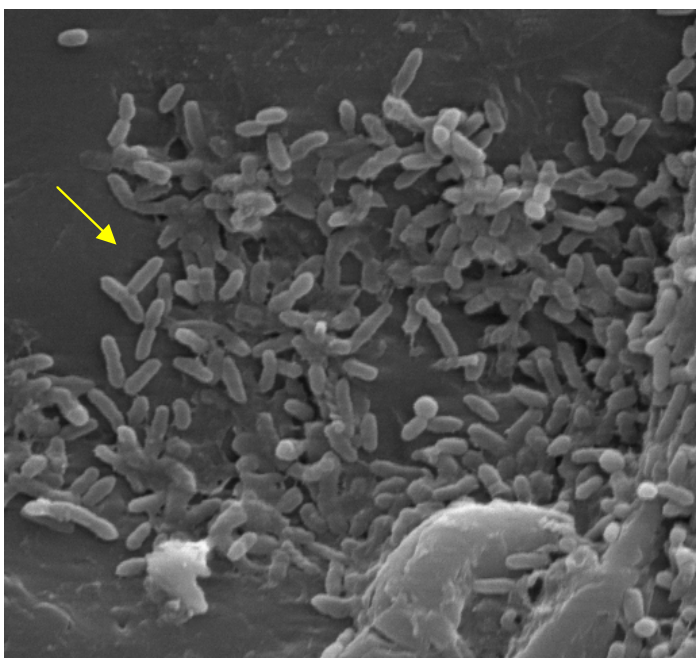

(c)

(Aumento $5000 \mathrm{x}$ )

Figura 5.14 - (a) bacilos ovalados; (b) cocos; (c) bacilos retos.

A Figura 5.15 foi obtida ao $116^{\circ}$ dia de operação com concentração média afluente de fenol de $430 \mathrm{mg} . \mathrm{L}^{-1}$ e de $323 \mathrm{mg} . \mathrm{L}^{-1}$ de $\mathrm{N}-\mathrm{NO}_{3}$. Pode-se observar que embora as morfologias continuem semelhantes as fases anteriores sendo predominantemente bacilos (5.15a) e esporadicamente cocos (5.15b), o aspecto do biofilme apresenta alteração, indicando início da formação de polímeros extracelulares. 


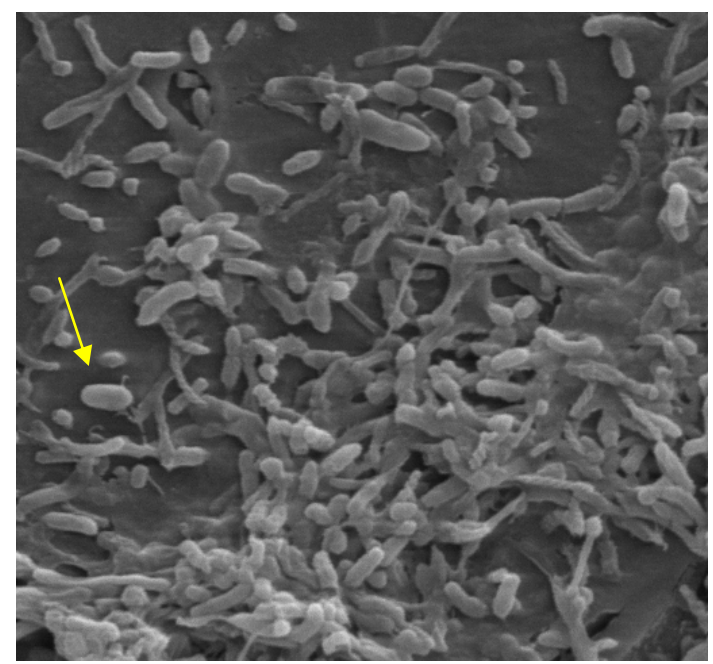

(a)

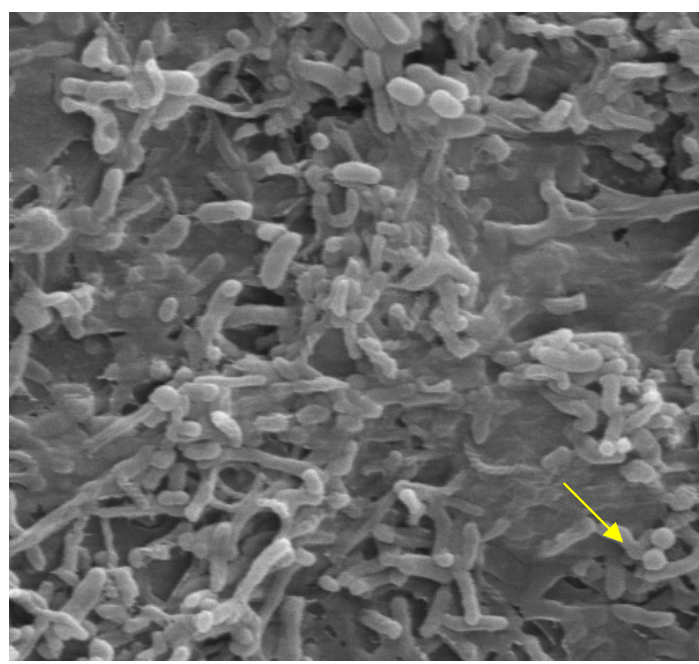

(b)

(Aumento $5000 \mathrm{x}$ )

Figura 5.15 - (a) bacilos ovalados; (b) cocos.

A Figura 5.15, mostra os microrganismos embebidos em matriz gelatinosa, fato até então não observado através das análises microbiológicas. Durante este período de operação do sistema, houve necessidade de três limpezas do reator (dias 81, 100 e 116), confirmando a alteração do biofilme concomitante ao surgimento de problemas operacionais.

No último dia de operação (dia $162^{\circ}$ ), antes do esvaziamento do reator, foi realizado um perfil microbiológico, a fim de se avaliar as morfologias de acordo com o afastamento da base do reator (zona de maior turbulência). Através de amostradores localizados ao longo do reator, foram coletadas partículas de três pontos com alturas equivalentes a 20,70 e $110 \mathrm{~cm}$.

O perfil foi realizado durante a quinta fase, quando a concentração média de fenol na entrada do sistema era de $518 \mathrm{mg} . \mathrm{L}^{-1}$, enquanto a de nitrogênio $360 \mathrm{mg} . \mathrm{L}^{-1}$. Durante esta fase foram observados os resultados mais baixos de eficiência de remoção de fenol e nitrogênio, cujos valores médios de eficiência foram de $68 \%$ para o fenol, e de apenas $51 \%$ para o nitrogênio.

A Figura 5.16 mostra as imagens obtidas de partículas coletadas a apenas $20 \mathrm{~cm}$ da base do reator. Todas as imagens mostram a presença de bacilos. No entanto, quando 
comparadas com as fotos das fases anteriores, aparentemente há diminuição da concentração de microrganismos, e mudança no aspecto do biofilme. Vale ressaltar que este ponto de coleta situa-se muito próximo ao ponto de alimentação e de recirculação do reator, sendo esta uma zona de alta turbulência, portanto, de constante desprendimento da biomassa.

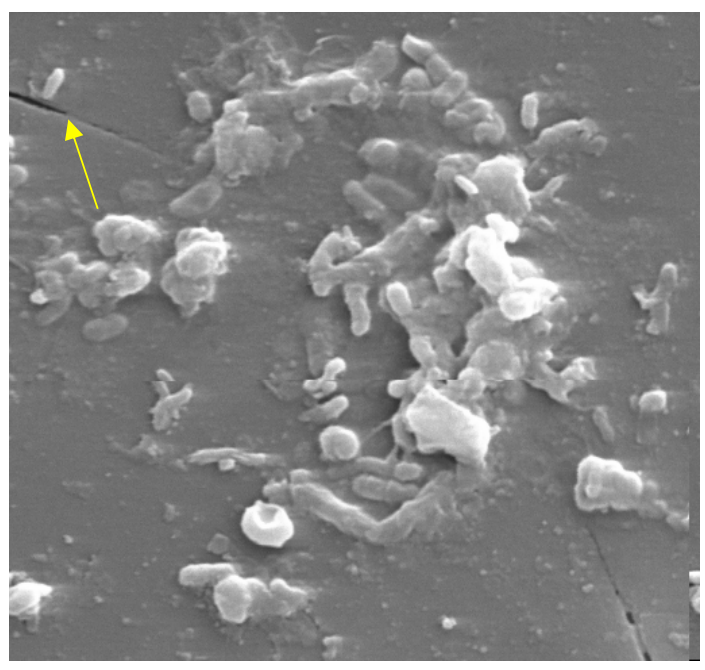

(a)

(Aumento $5000 \mathrm{x}$ )

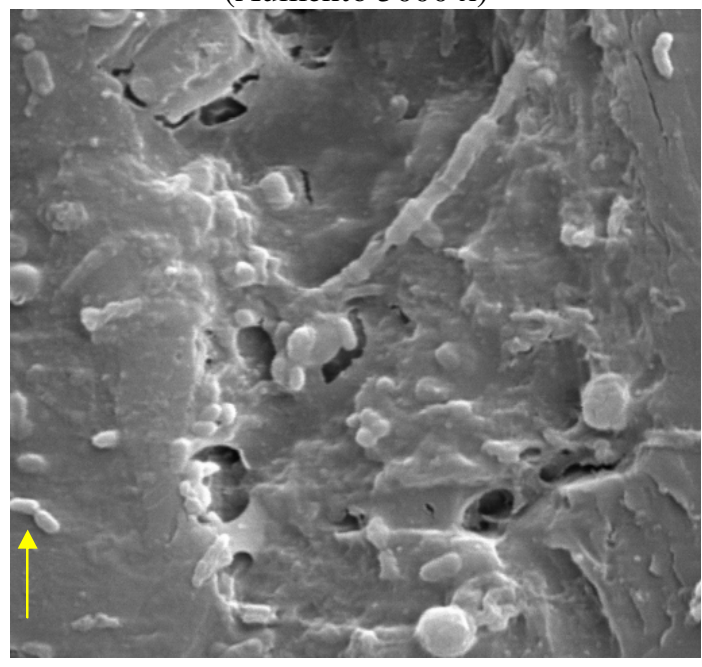

(c)

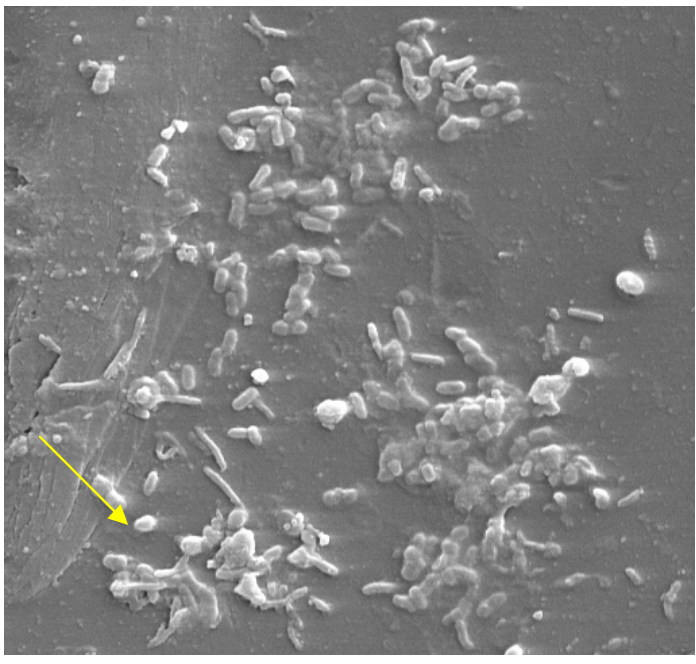

(b)

(Aumento $3000 \mathrm{x}$ )

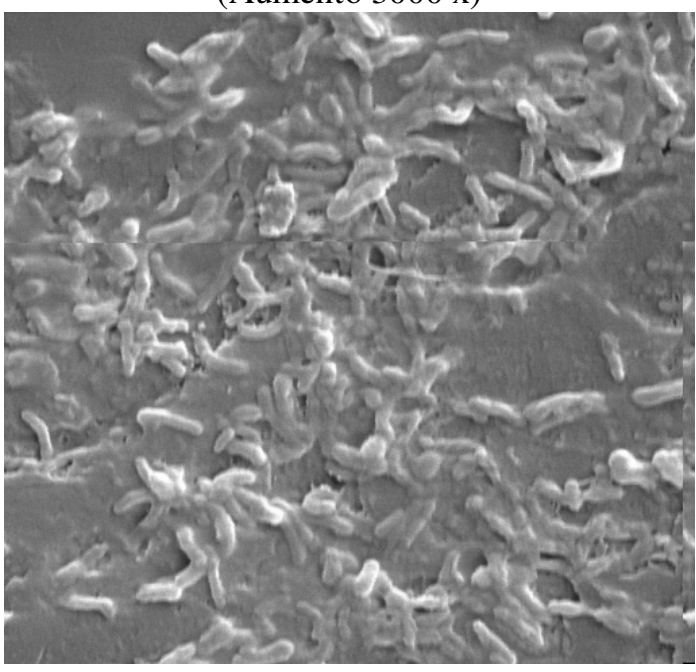

(d)

(Aumento $5000 \mathrm{x}$ )

(Aumento $5000 \mathrm{x}$ )

Figura 5.16 - (a) bacilos ovalados; (b) cocos; (c) bacilos; (d) microrganismos envolvidos em uma camada gelatinosa. 
A Figura 5.17 mostra os resultados das análises obtidas no perfil cujo ponto de coleta foi correspondente a altura de $70 \mathrm{~cm}$ da base. Aparentemente, as partículas coletadas neste ponto apresentaram maior quantidade de biofilme aderida ao meio suporte. No entanto, observou-se alteração na morfologia com a presença de espiroquetas.

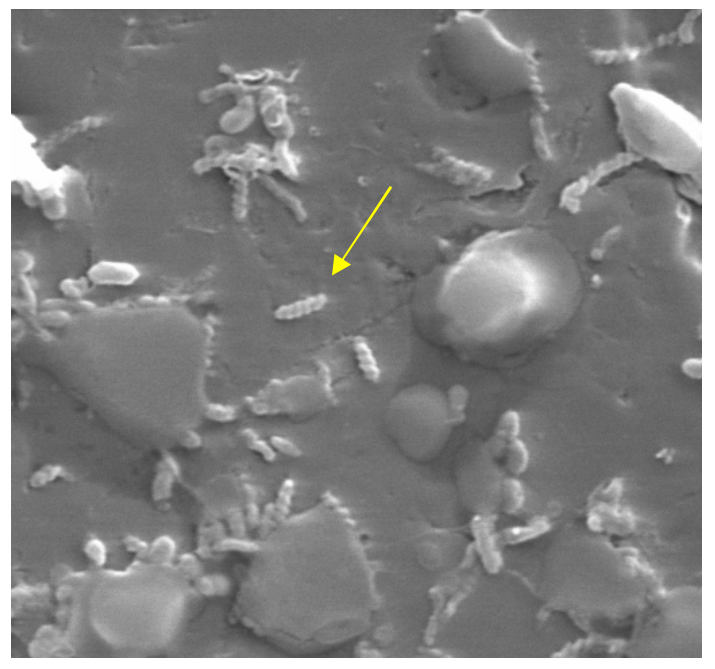

(a)

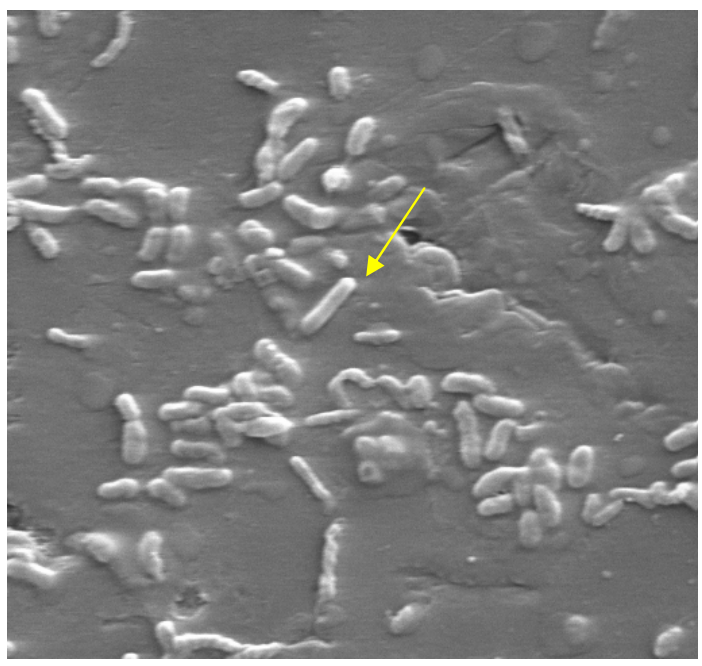

(b)

(Aumento $5000 \mathrm{x}$ )

Figura 5.17 - (a) espiroquetas; (b) bacilos.

Duarte (2006) estudou reatores anaeróbios horizontais de leito fixo (RAHLF) empregados para remoção de alquilbenzeno linear sulfonado (LAS), inoculados com lodos anaeróbios provenientes de reatores UASB usados no tratamento de esgoto sanitário (R1) e tratamento de dejetos de suinocultura (R2), respectivamente, ambos imobilizados em espuma de poliuretano. Durante a operação do sistema, houve colmatação dos leitos e bacilos e cocos fluorescentes não foram mais observados. Porém, a presença de espirilos foi constatada ao longo do reator R1. A autora atribuiu essa mudança na predominância das morfologias ao desequilíbrio dos reatores e ao longo tempo de exposição da biomassa ao LAS; ou seja, por período de 144 dias. 
Essa constatação também pode ser aplicada a este trabalho, tendo em vista os efeitos deletérios que o fenol causa em altas concentrações e principalmente por um período superior (162 dias) ao citado por Duarte (2006).

A Figura 5.18 é referente ao último ponto de coleta de partícula para o perfil, a 110 $\mathrm{cm}$ da base do reator, que mostra com clareza a existência de gradientes espaciais de microrganismos em função da diminuição substancial da turbulência, podendo ser observada uma população mais densa e, sobretudo, com grande quantidade de polímeros.

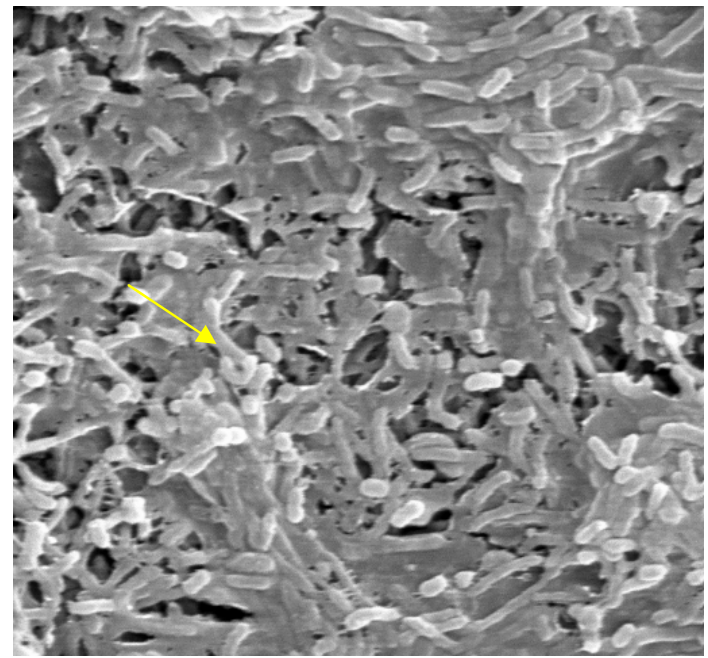

(a)

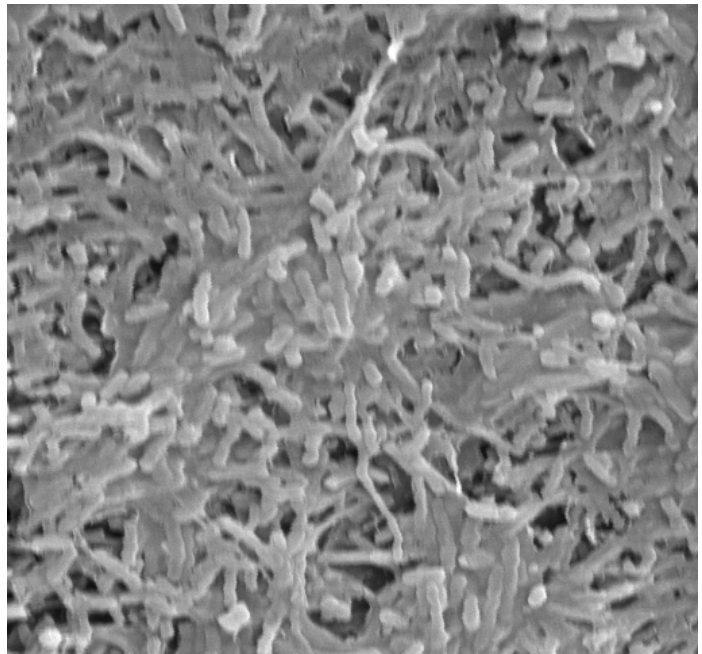

(b)

(Aumento $5000 \mathrm{x})$

(Aumento $5000 \mathrm{x}$ )

Figura 5.18 - (a) bacilos curvos e (b) microrganismos envolvidos em matriz polimérica.

Rabah e Dabah (2004b) também realizaram um perfil para avaliar a concentração da biomassa, a espessura do biofilme e a porosidade do leito ao longo da altura de um reator de leito fluidificado. Os autores observaram que a maior concentração de microrganismos estava localizada no fundo do reator e que esta decrescia conforme as partículas se afastavam da base em direção ao topo. Este fato foi atribuído ao incremento da porosidade do leito ao longo do reator que implica em poucas biopartículas por unidade de volume e consequentemente menor 
concentração de biomassa. No entanto, a espessura do biofilme aumentou do fundo para o topo indicando estratificação do leito. Esta estratificação é o resultado da variabilidade da densidade das biopartículas no reator. Assumindo que as partículas têm o mesmo tamanho, as biopartículas com biofilmes mais finos são mais densas do que as com biofilmes mais espessos, que por sua vez ocupam a parte superior do leito.

As imagens de microscopia não permitem afirmar com precisão sobre a concentração de biomassa, especialmente porque nitidamente há formação de polímeros à medida que as partículas se afastam da base. Além disto, dependendo do ângulo que a imagem é obtida pode haver grande diferença de resultados, pois o poliestireno é fabricado em fios, que, quando são cortados, apresentam maior rugosidade nas seções transversais, onde são preferencialmente ocupados pela biomassa. No entanto, a espessura do biofilme aumentou conforme descrito por Rabah e Dabah (2004b), corroborando com a hipótese de estratificação do leito.

Hwang et al. (2006) comentam que há poucos relatos sobre a flotação deste tipo de biofilme em reatores de leito fluidificado. No entanto, a experiência dos autores com sistemas de lodos ativados mostrou que o déficit de fósforo pode causar uma superprodução de polímeros extracelulares. Diante dos problemas operacionais supracitados, os autores optaram por adicionar diretamente $\mathrm{KH}_{2} \mathrm{PO}_{4}$, com concentração de fósforo correspondendo a $5 \mathrm{mg} . \mathrm{L}^{-1}$, e concomitante a adição de $\mathrm{P}$, também foi reduzida a taxa de carregamento de nitrogênio de $0,2 \mathrm{~kg} \cdot \mathrm{d}^{-1}$ para $0,1 \mathrm{~kg} . \mathrm{d}^{-1}$. Desde então, a flotação da biomassa foi eliminada e a eficiência de remoção de nitrogênio recuperada.

Além dos exames microbiológicos, houve também o monitoramento da quantidade de biomassa perdida no efluente representada pelos sólidos suspensos voláteis (SSV). Embora não representem exatamente a fração ativa da biomassa presente, os sólidos voláteis ainda têm sido utilizados de forma a atender as necessidades práticas para controle de rotina. 
A Figura 5.19 mostra a variação de SSV ao longo da operação. Durante a partida do sistema, em função do acréscimo inicial de $10 \%$ de inóculo do volume total do reator, houve redução da concentração de biomassa de $158 \mathrm{mg} . S S V . L^{-1}$ para em média $56 \mathrm{mg} . \mathrm{SSV} . \mathrm{L}^{-1}$. Na segunda fase, o acréscimo médio foi ínfimo e assim permaneceu até o final da quarta fase ( $100^{\circ}$ dia de operação). No entanto, durante a transição da fase IV para V e na fase V, o valor médio da concentração efluente passou para $107( \pm 14) \mathrm{mg} . \mathrm{SSV} \cdot \mathrm{L}^{-1}$, evidenciando, assim, perda de biomassa em função das mudanças desfavoráveis das condições operacionais.

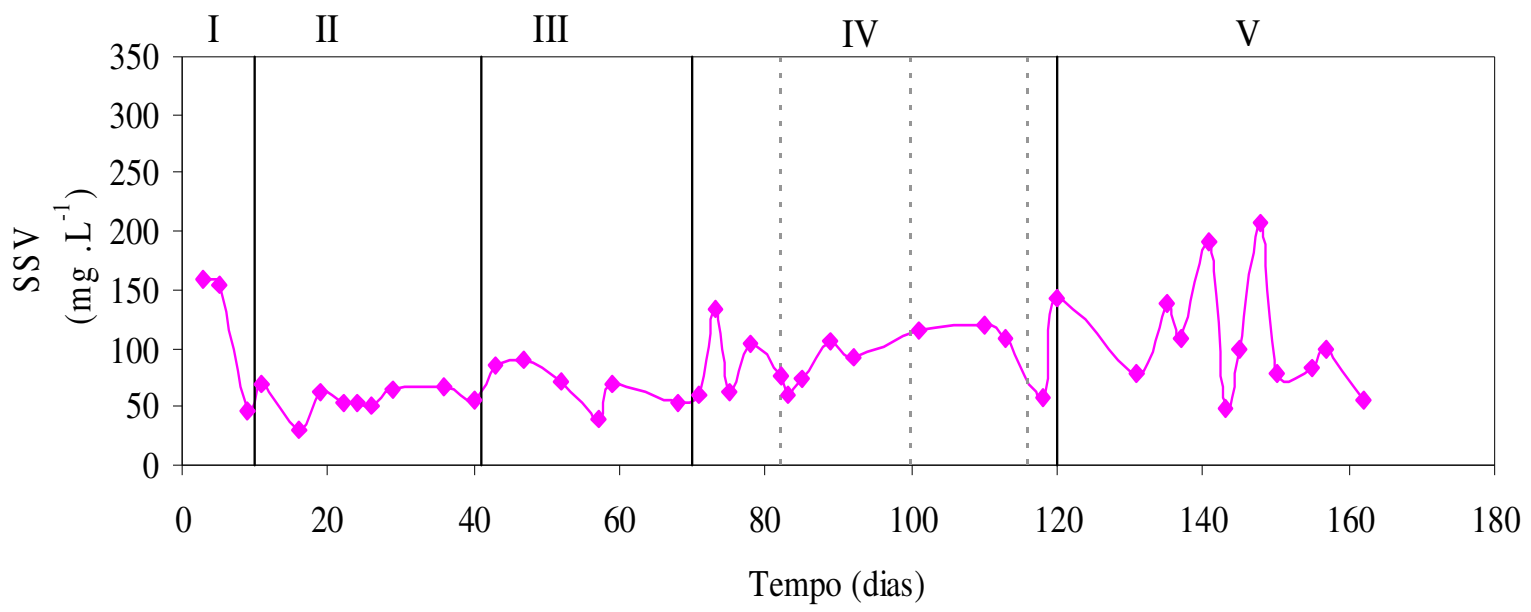

Figura 5.19 - Variação das concentrações de sólidos suspensos voláteis no efluente (»), mudanças de fases (-) e dias de realização de limpeza e manutenção do reator (-"*).

Eiroa et al. (2005) observaram a biodegradação do fenol e do formaldeído, durante o processo de desnitrificação em reator UASB, que houve incremento da concentração de biomassa dentro do reator de 8,5 para 13,1 g.SSV.L -1 $^{-1}$ ate o dia $137^{\circ}$ de operação. No entanto, neste dia, houve perda de biomassa remanescendo 7,6 g.SSV.L ${ }^{-1}$. A concentração de biomassa então voltou a aumentar atingindo valor de 10,1 g.SSV.L ${ }^{-1}$, que se manteve até o final da operação (245 dia). Em um reator de leito fluidificado, principalmente quando o meio suporte é poliestireno, a quantificação da biomassa ativa aderida é uma tarefa bastante difícil de ser realizada. Primeiro porque, como já foi mostrado no perfil microbiológico, pode haver 
estratificação do leito, e segundo porque, uma vez que o biofilme é aderido, a remoção se torna bastante difícil; seja por retirada mecânica (agitação); seja pela ação de produto químico $(\mathrm{NaOH})$, onde ambos podem danificar o material suporte e interferir nos resultados.

Com relação à biomassa perdida no efluente, Eiroa et al. (2005) observaram que houve decréscimo durante os primeiros dias de operação. Quando o sistema permaneceu estável, a concentração da biomassa no efluente variou entre 6 e $24 \mathrm{mg} . \mathrm{SSV} . \mathrm{L}^{-1}$, com valor médio de $16 \mathrm{mg} . \mathrm{SSV} . \mathrm{L}^{-1}$. Assim, pode-se concluir que o lodo produzido apresentou boas características de sedimentação e com baixa perda de sólidos suspensos voláteis no efluente. Contudo, foi observada retenção de bolhas de gás produzidas durante a operação que provocaram flotação do lodo. Quando a concentração de fenol afluente passou para 1010 mg.L $\mathrm{L}^{-1}$, a concentração da biomassa no efluente foi desestabilizada, variando entre 22 a 74 g.SSV.L ${ }^{-1}$, durante este período.

Considerando os desvios padrões, os resultados obtidos neste trabalho são coerentes com os valores encontrados pelos autores. No entanto, a perda máxima de biomassa relatada por Eiroa (2005) foi inferior, mesmo com concentrações de fenol muito superiores às deste trabalho. Este fato pode ser associado principalmente ao tipo de suporte ao qual a biomassa foi imobilizada e à turbulência ao qual o leito fluidificado foi submetido.

Aparentemente, analisando as concentrações de SSV, não se pode afirmar que houve grandes perdas de biomassa, mediante as realizações de limpeza e dos aumentos progressivos das concentrações de carbono orgânico e nitrogênio.

Fato semelhante foi constatado por Rabah e Dabah (2004a), que verificaram que a concentração média de biomassa no reator de leito fluidificado decresceu com incremento da taxa de carregamento de nitrogênio. No entanto, esta diminuição foi desprezível. Os autores relatam que, para velocidade superficial (Vs) de $55 \mathrm{~m} \cdot \mathrm{h}^{-1}$, a concentração média de biomassa 
diminuiu de 25 para 23 g SSV, mesmo sob um aumento considerável na taxa de carregamento de nitrogênio de 6 para 8 kg.N.m ${ }^{-3}$ leito.d ${ }^{-1}$.

Fato contrário ocorreu quando as mudanças foram hidrodinâmicas. Os autores observaram que para uma taxa de carregamento de nitrogênio de $6 \mathrm{~kg} . \mathrm{N} \cdot \mathrm{m}^{-3}$ leito.d $\mathrm{d}^{-1}$, a concentração média de biomassa diminuiu de 33 para 21 g.SSV.L ${ }^{-1}$ leito, quando a Vs foi acrescida de 45 para $65 \mathrm{~m} \cdot \mathrm{h}^{-1}$. Os autores atribuem este decréscimo a dois fatores: quando a Vs aumenta, a porosidade do leito também aumenta conduzindo para uma baixa concentração de biopartículas por unidade de volume do reator. Como conseqüência, têm-se baixa concentração de biomassa. Além disso, o aumento do Vs implica em maior cisalhamento entre partícula/partícula e partícula/parede, provocando estresse no biofilme causando desprendimento.

Algumas frações de sólidos suspensos podem ser relacionadas entre si, apresentando informações importantes. É o caso da relação SSV/SST que representa o grau de mineralização do lodo.

A Figura 5.20 mostra os valores da relação SSV/SST, que foi em média 0,85 para todas as fases. Entretanto, sempre quando houve mudança de fase e manutenção do reator, a relação aumentou, ou seja, a quantidade de biomassa em relação aos sólidos voláteis totais na saída foi acrescida. 


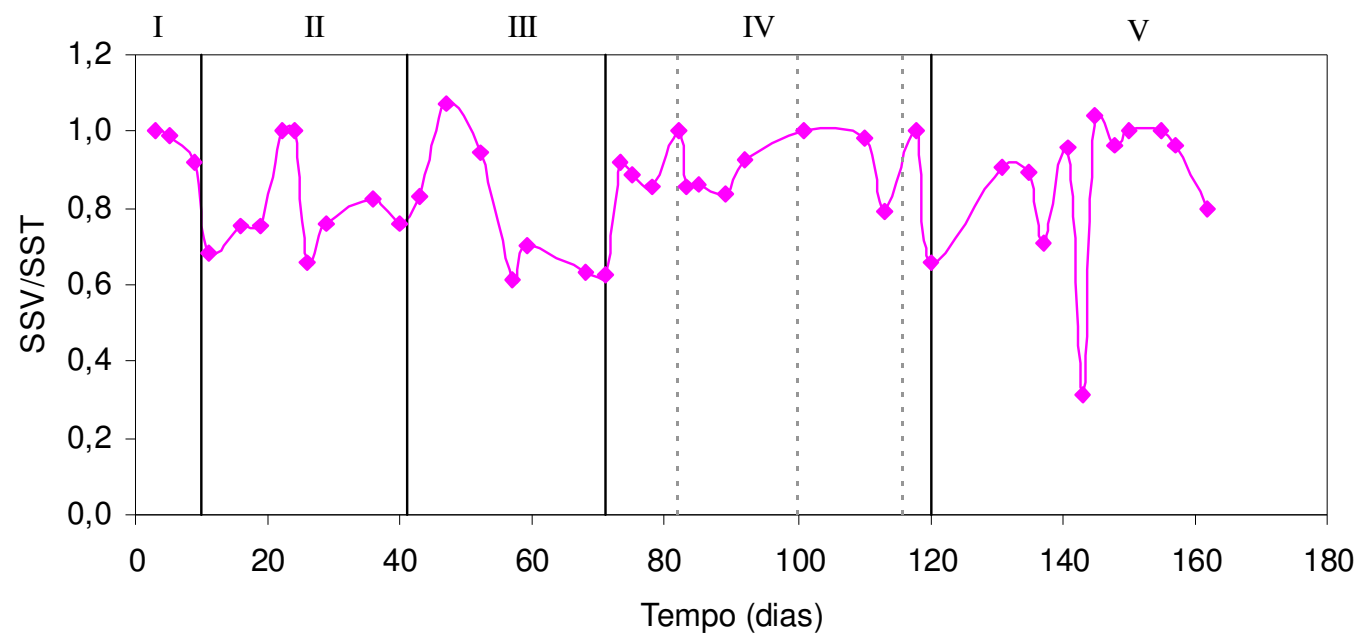

Figura 5.20 - Relação entre SSV/SST no efluente ( $\downarrow)$, mudanças de fases (-) e dias de realização de limpeza e manutenção do reator ("-").

Com essa constatação pode-se inferir que quantitativamente os sólidos suspensos voláteis não sofreram consideráveis alterações, mas sim qualitativamente. Isto pode ser um indicativo de que pode ter havido desprendimento da cultura desnitrificante para seleção de microrganismos capazes de realizar degradação, conforme as mudanças de condições operacionais.

Os resultados são bastante coerentes com os obtidos por Dombroski (2003), que realizou vários testes para avaliação do potencial de uma cultura desnitrificante na biodegradação de compostos fenólicos. A autora constatou o aumento progressivo das relações entre SSV/SST $(0,89,0,89,0,91,0,91$ e 0,93$)$ face a diminuição dos tempos de retenção celular que foram de 60, 57, 41, 29 e 23, respectivamente. 


\section{CONCLUSÕES}

Os resultados apresentados mostram que o reator de leito fluidificado é um sistema robusto, com grande potencial em reduzir altas concentrações de compostos fenólicos, eliminando concomitantemente compostos nitrogenados sob a forma de nitrato.

Durante o período de adaptação, os comportamentos do consumo de fenol e nitrogênio foram semelhantes, mostrando que estequiometricamente o sistema estava equilibrado, já que durante este período a concentração de fenol foi muito baixa, ou seja, não havia ainda efeito inibitório.

Os resultados experimentais obtidos neste estudo mostraram que para concentrações de fenol de até $430 \mathrm{mg} \cdot \mathrm{L}^{-1}$, a eficiência de remoção foi em torno de $80 \%$, não tendo sido detectada presença de fenol no efluente para concentrações de até $335 \mathrm{mg} . \mathrm{L}^{-1}$.

O sistema operou com TCF aplicada variando entre 0,07 e $0,79 \mathrm{~kg}$.fenol. $\mathrm{m}^{-3} \cdot \mathrm{dia}^{-1}$, para concentrações de fenol correspondentes entre 52 a $518 \mathrm{mg} . \mathrm{L}^{-1}$. Para taxa de carregamento máxima a remoção de eficiência foi de aproximadamente $70 \%$.

A formação de biopolímeros acarretou em vários problemas operacionais, que forçaram abertura do sistema provocando prováveis mudanças ambientais que desfavoreceram o processo. Além disto, o acúmulo desde lodo bastante floculento, prejudicou a bomba de recirculação, diminuindo a expansão do leito e aumentando a taxa de carregamento. Esses problemas operacionais aliados ao aumento progressivo da concentração de fenol prejudicaram o desempenho do sistema.

Quanto a remoção de nitrogênio, as concentrações aplicadas no afluente foram de 45 , 79, 157, 260, 323, 362 mg.N - $\mathrm{NO}_{3} \cdot \mathrm{L}^{-1}$ cujas eficiências de remoções foram de 94, 89, 86, 79, $63,51 \%$, respectivamente. As taxas de carregamento variaram entre 0,05 e $0,5 \mathrm{~kg} . \mathrm{N}-\mathrm{NO}_{3} . \mathrm{m}^{-}$ 
${ }^{3}$.dia ${ }^{-1}$. Não foi observado acúmulo de nitrito no efluente para praticamente toda operação, com exceção do final da quinta fase.

Para uma relação $\mathrm{C} / \mathrm{N}-\mathrm{NO}_{3}$ correspondendo a aproximadamente 1 , cerca de $3,8 \mathrm{~g}$ DQO foram consumidos por $\mathrm{g}$ de $\mathrm{N}-\mathrm{NO}_{3}$ removido, valor superior ao teórico face a necessidade de fonte extra de carbono pra crescimento celular. Os valores de DQO afluente foram $715,926,1240,1519,1873,1529$ mg. $\mathrm{L}^{-1}$, com valores de eficiência de redução de 83, $92,88,88,73,68 \%$, respectivamente.

$\mathrm{O}$ pH esteve situado na faixa de variação para efluente entre 7,64 a 8,35, não havendo necessidade de correção com alcalinizantes, sendo esta faixa típica para sistemas biológicos que realizam desnitrificação.

Quanto as concentrações de alcalinidade a bicarbonato, houve aumento conforme as mudanças de fases, com exceção de dois instantes; o primeiro quando foi cessado o período de adaptação e foi dado o início da operação contínua do sistema (redução de 948 para 298 mg. $\mathrm{CaCO}_{3} \mathrm{~L}^{-1}$ ), face ao acúmulo de compostos intermediários. E um instante que ocorreu durante a $\mathrm{V}$ e última fase em função da baixa eficiência de redução de nitrato, principal gerador de alcalinidade do sistema. Desta forma, os valores médios de alcalinidade a bicarbonato durante a operação do sistema foram 554, 473, 312, 755, 855 e 694 mg.CaCO ${ }_{3} \mathrm{~L}^{-}$ 1.

Não foi observado acúmulo de ácidos voláteis no sistema, mesmo quando operado sob altas taxas de carregamento de fenol e nitrogênio.

Quanto às morfologias observadas, o predomínio foi de bacilos para todas as fases, com presença esporádica de cocos. Após os distúrbios provocados pelo efeito tóxico do fenol que acarretou na formação excessiva de polímeros extracelulares, foi observado também a presença de morfologias espiraladas. È provável que esse distúrbio possa ter sido potencializado pelo desequilíbrio de algum nutriente, como fósforo, já que a composição da 
água residuária sintética foi inalterada (com exceção do carbono e nitrogênio) durante todo o experimento.

O experimento teve duração equivalente a 162 dias, nos quais o sistema mostrou resultados satisfatórios para redução de carbono e nitrogênio, mesmo quando operado com elevadas concentrações de fenol e nitrato. 


\section{RECOMENDAÇÕES}

Tendo em vista a colaboração com outras pesquisas futuras relacionadas com a remoção biológica de fenol e nitrogênio, recomenda-se que:

i. Inocular o reator de preferência com cultura adaptada aos compostos fenólicos e aos compostos nitrogenados.

ii. Para o caso de estudos com cultura desnitrificante, é recomendável o emprego de decantador, especialmente em reatores que necessitam de recirculação, como é o caso do reator de leito fluidificado. Este dispositivo deverá diminuir a necessidade de abertura do sistema para realização de limpeza para remoção de lodo.

iii. Monitorar o potencial redox, já que este parâmetro parece ser mais indicado para o monitoramento do processo de desnitrificação, quando comparado ao $\mathrm{pH}$.

iv. Fazer acompanhamento dos compostos gasosos nitrogenados, para certificação de que não há formação de outros compostos que não gás nitrogênio, já que este é a garantia da desnitrificação completa.

v. Identificar os produtos intermediários da degradação anóxica do fenol e correlacionálos com os microrganismos presentes; 
vi. Avaliar o emprego de diferentes co-substratos para melhorar a eficiência do tratamento do fenol;

vii. Fazer perfil dos macronutrientes e variar a relação destes, conforme o aumento da principal fonte de carbono e/ou nitrogênio;

viii. Realizar estudos cinéticos para elucidar melhor as condições ótimas de operação para sistemas semelhantes a este;

ix. Fazer estudo de atividade desnitrificante e determinação do número mais provável de microrganismos responsáveis pela mineralização do nitrogênio sob a forma de nitrato;

x. Aplicar técnicas de biologia molecular para determinação dos microrganismos envolvidos no processo, bem como as alterações que a comunidade sofre face às mudanças de condições operacionais. 


\section{REFERÊNCIAS BIBLIOGRÁFICAS}

AKUNNA, J. C.; BIZEAU, C.; MOLETTA, R. Nitrate and nitrite reductions with anaerobic sludge using various carbon sources: glucose, glycerol, acetic acid, lactic acid and methanol. Water Research, v. 27, n. 8, p. 1303 - 1312, 1993.

ALVES, C. F.; MELO, L.F.; VIEIRA, M.J. Influence of medium composition on the characteristics of a denitrifying biofilm formed by Alcaligenes denitrificans in a fluidized bed reactor. Process Biochemistry, v. 37, p. 837 - 845, 2002.

AMORIM, E. L. C. Desempenho de reator anaeróbio de leito fluidificado operado sob condições de aumento progressivo de carga orgânica no tratamento de fenol. Dissertação (Mestrado) - São Carlos - SHS - EESC - USP, 2007.

APHA - American Public Health: Standard Methods for the Examination for Water and Wastewater. 17th ed. New York. 1995.

ARAÚJO, J. C. Caracterização e evolução do biofilme em reator de leito fluidificado alimentado com esgoto sanitário sintético. Dissertação (Mestrado) - São Carlos - SHSEESC-USP, 1995.

ASSALIN, M. R.; SILVA, P.L.; DURAN, N. Comparação da eficiência do processo de ozonização e ozonização catalítica (Mn II e Cu II) na degradação de fenol. Química Nova. v. 29, p. 24 - 27, 2006.

ATSDR - AGENCY FOR TOXIC SUBSTANCES AND DISEASE REGISTRY. Toxicological profile for phenol. Update. Atlanta, GA, 2006. Disponível em: http://www.atsdr.cdc.gov/toxprofiles/tp115.pdf

AUN, M. V. Contribuição ao estudo da desnitrificação utilizando fenol como fonte de carbono. Dissertação (Mestrado), ) - Escola Politécnica, Universidade de São Paulo, São Paulo, 2001.

BAI, J.; WEN, J.; LI, H.; JIANG, Y. Kinetic modeling of growth and biodegradation of phenol and m-cresol using Alcaligenes faecalis. Process Biochemistry, v. 42, p. 510 - 517, 2007. 
BAKKER, G. Anaerobic degradation of aromatic compounds in the presence of nitrate. FEMS Microbiology Letters, v. 1, p. 103 - 108, 1977.

BERNET, N.; SANCHEZ, O.; CESARON, D.; STEYER, J. P.; DELGENÈS, J. P. Modeling and control of nitrite accumulation in a nitrifying biofilm reactor. Biochemical Engineering Journal, v. 24, p. 173 - 183, 2005.

BLANCO, V. D.; ENCINA, P. A. G.; POLANCO, F. F. Effects of biofilm growth, gas and liquid velocities on the expansion of an anaerobic fluidized bed reactor (AFBR), Water Research, v. 29, n. 7, p. 1649 - 1654, 1995.

BOOPATHY, R. Isolation and characterization of a phenol-degrading, sulfate-reducing bacterium from swine manure. Bioresource Technology, v. 54, p. 29 - 33, 1995.

BROHOLM, M. M.; CROUZET, C.; ARVIN, E.; MOUVET, C. Concurrent nitrate and Fe III reduction during anaerobic biodegradation of phenols in a sandstone aquifer. Journal of Contaminant Hydrology, v. 44, p. 275 - 300, 2000.

CETESB - COMPANHIA DE TECNOLOGIA DE SANEAMENTO AMBIENTAL, Determinação de fenóis em águas - Método Colorimétrico da 4 - amino - antipirina. L5. 125 set 1990.

CHEN, K. C.; LIN, Y. F. The relationship between denitrifying bacteria and methanogenic bacteria in a mixed culture system of acclimated sludges. Water Research, v. 27, p. 1749 1759, 1993.

CHIU, Y.; CHUNG, M. Determination of optimal COD/nitrate ratio for biological denitrification. International Biodeterioration \& Biodegradation, v. 51, p. 43 - 49, 2003.

COSTA, S. R. A. Remoção de fenol em reator anaeróbio de leito fluidificado de carvão ativado. São Carlos. Tese (Doutorado) - SHS-EESC-USP, 1994.

CUENCA, M. A.; VEZULI, J.; LOHI, A.; UPRETI, S. R. Anaerobic biodegradation of diesel fuel-contaminated wastewater in a fluidized bed reactor. Bioprocess Biosyst. Engineering, v. 29, p. 29 - 37, 2006.

DILALlO, R; ALBERTSON, O.E. Volatile Acids by direct titration. Journal of Water Pollution Control Federation, v. 33, n. 4, 356 - 365, 1961. 
DOMBROSKI, S. A. G. Nitrificação e desnitrificação de água residuária de coqueria utilizando fonte interna de carbono. Tese (doutourado) - Escola Politécnica, Universidade de São Paulo, São Paulo, 2003.

DUARTE, I. C. S. Caracterização microbiológica da remoção e degradação de Alquilbenzeno Linear Sulfonado (LAS) em reatores anaeróbios com biofilme e células planctônicas. Tese (Doutorado) - Escola de Engenharia de São Carlos, Universidade de São Paulo, São Carlos, 2006.

EIROA, M.; VILAR, A.; AMOR, L.; KENNES, C.; VEIGA, M. C. Biodegradation and effect of formaldehyde and phenol on the denitrification process. Water Research, v. 39, p. 449 455, (2005)

FANG, H. H. P.; LIANG, D.W.; ZHANG, T.E.; LIU, Y. Anaerobic treatment of phenol in wastewater under thermophilic condition. Water Research, 40: 427 - 434, 2006.

FANG, H. H. P.; ZHOU, G. Interacions of methanogens and denitrifiers in degradation of phenols. Journal of Environmental Engineering, v. 125, p. 57 - 63, 1999.

FANG, H. H. P; CHAN, O. Toxicity of Phenol Towards Anaerobic Biogranules. Water Research, v. 31, p. 2229 - 2242, 1997.

FOGLAR, L.; BRIŠKI, F. Wastewater denitrification process: The influence of methanol and kinetic analysis. Process Biochemistry, v. 39, p. 95 - 103, 2003.

GAVRILESCU, M. Engineering concerns and new developments in anaerobic waste-water treatment. Clean Technology Environmental Policy, v. 3, p. 346 - 362, 2002.

GEORGIOU, D.; AIVASIDIS, A. Decoloration of textile wastewater by means of a fluidized - bed loop reactor and immobilized anaerobic bacteria. Journal of Hazardous Materials, v. 135, p. 372 - 377, 2006.

GRADY JR.; C. P .L; DAIGGER, G. T; LIM, H. C. Biological Wastewater Treatment. $2^{\text {nd }}$ Edition. Marcel Dekker, 1999.

GUSMÃO, V.R. Caracterização microbiológica de cultura desnitrificante de reator anaeróbio horizontal de leito fixo utilizado na remoção de BTEX. Tese (Doutorado) Escola de Engenharia de São Carlos, Universidade de São Paulo, São Carlos, 2005. 
HARWOOD, C. S.; BURCHHARDT, G.; HERRMANN, H.; FUCHS, G. Anaerobic Metabolism of Aromatic Compounds Via the Benzoyl - CoA Pathway. FEMS Microbiology Reviews, v. 22, p. 439 - 458, 1999.

HEIDER, J.; FUCHS, G. Microbial Anaerobic Aromatic Metabolism. Anaerobe, v. 3, p. 1 22, 1997.

HER, J.; HUANG, J. Influences of carbon source and $\mathrm{C} / \mathrm{N}$ ratio on nitrate/nitrite denitrification and carbon breakthrough. Bioresource Technology, v. 54, p. 45 - 51, 1995.

HIDALGO, M. D.; ENCINA, P. A. G. Biofilm development and bed segregation in a methanogenic fluidized bed reactor Water Research v. 36, p. 3083 - 3091, 2002.

HOLST, T. C.; TRUC, A.; PUJOL, R. Anaerobic fluidized beds: ten years of industrial experience. Water Science Technology, v. 36, n. 6 e 7;p. 415 - 422, 1997.

HWANG, C.; WU, W. M.; GENTRY, T. J.; CARLEY, J.; CARROLL, S. L.; SCHADT, C.; WATSON, D.; JARDINE, P. M.; ZHOU, J.; HICKEY, R. F.; CRIDDLE, C. S; FIELDS, M. W. Changes in bacterial community structure correlate with in initial operating conditions of a field-scale denitrifying fluidized bed reactor. Applied Microbiol Biotechnology, v. 71, p. $748-760,2006$.

IAMAMOTO, C.Y. Remoção de nitrogênio de águas residuárias com elevada concentração de nitrogênio amoniacal em reator contendo biomassa em suspensão operado em bateladas seqüenciais e sob aeração intermitente. Tese (doutorado) - Escola de Engenharia de São Paulo, São Carlos, 2006.

KARIM, K.; GUPTA, S. K. Effects of alternative carbon sources on biological transformation of Nitrophenols. Biodegradation, v. 13, p. 353 - 360, 2002.

KARLSSON, A.; EJLERTSSON J.; NEZIREVIC D.; SVENSSON B. H. Anaerobe Degradation of Phenol Under Meso- and Thermophilic, Anaerobic Conditions. Anaerobe, v. 5, p. 25 - 35, 1999.

LACK, A.; FUCHS G. Evidence that phenol phosphorylation to phenylphosphate is the first step in anaerobic phenol metabolism in a denitrifying Pseudomonas sp. Archives of Microbiology, v. 161, n. 2, p.132 - 139, 1994.

LAKSHIMI, L.P.; SETTY, Y.P. Liquid-solid mass transfer in a two phase fluidized bed bioreactor. Chemical Engineering Journal, article in press, (2007). 
LEE, N. M.; WELANDER, T. The effect of different carbon sources on respiratory denitrification in biological wastewater treatment. Journal of Fermentation and Bioengineering, v. 82, n. 3, p. 277 - 285, 1996.

LONDRY, K. L; FEDORAK, P. M. Benzoic acid intermediates in the anaerobic biodegradation of phenol. Canadian Journal Microbiology, v. 38: p. 1 - 11, 1992.

LUOSTARINEN, S.; LUSTE, S.; VALENTÍN, L.; RINTALA, J. Nitrogen removal from onsite treated anaerobic effluents using intermittently aerated moving bed biofilm reactors at low temperatures. Water Research, v. 40, p. 1607 - 1615, 2006.

MAGARITIS, A.; PEACE, G.W. Microbial polysaccharides. Comprehensive Biotechnology. The Principles, Applications and Regulations of Biotechnology in Industry, Agriculture and Medicine. Ed.Pergamn Press, v. 3,1986.

MARTINELLI, F.R. Formação e desenvolvimento de biofilme em reator de leito fluidificado na degradação anaeróbia de fenol. (Trabalho de graduação) - Departamento de Engenharia Química - UFSCar, 2003.

MINISTÉRIO DO MEIO AMBIENTE - CONAMA - CONSELHO NACIONAL DO MEIO AMBIENTE - RESOLUÇÃO n. 357, 17 de março de 2005. Disponível em: http://www.mma.gov.br/port/conama/res/res05/res35705.pdf

MENGISTU, Y., EDWARDS, C., SAUNDES, J.R. Continuous culture studies on the synthesis of capsular polysaccharide by Klebsiella pneumoniae K1. Journal of Applied Bacteriology, v. 76, p. $424-430,1994$.

MIQUELETO, A. P. Polímeros extracelulares insolúveis (EPS) nos reatores anaeróbios operados em bateladas seqüenciais: caracterização e fatores que favorecem a produção. Tese: (Doutourado). São Carlos - SHS - EESC - USP, 2006.

MORAES, E. M.; ADORNO; M. A. T.; ZAIAT, M., FORESTI, E. Determinação de ácidos voláteis por cromatografia gasosa em efluentes de reatores anaeróbios tratando resíduos líquidos e sólidos. Anais da VI Oficina e Seminário Latino-Americano de Digestão Anaeróbia. Editora Universitária - UFPE. v.2. p.235-238, 2000.

MOTELEB, M. A.; SUIDAN, M. T.; KIM, J.; MALONEY, S. W. Pertubated loading of a formaldehyde waste in an anaerobic granular activated carbon fluidized bed reactor. Water Research. v. 29, n. 7, p. 1649 - 1654, 1995. 
QUEIROZ, L. M. Estudo da remoção biológica de nitrogênio via nitrito utilizando fenol como fonte de carbono operando um reator em bateladas sequienciais (SBR) em escala piloto. Dissertação (Mestrado) - Escola Politécnica, Universidade de São Paulo, São Paulo, 2006.

RABAH, F. K. J.; DAHAB, M. F. Biofilm and biomass characteristics in high-performance fluidized-bed biofilm reactors. Water Research, v. 38, p. 4262 - 4270, $2004 \mathrm{a}$.

RABAH, F. K. J.; DAHAB, M. F. Nitrate removal characteristics of high performance fluidized-bed biofilm reactors. Water Research, v. 38, p. 3719 - 3728, 2004 b.

RAJESHWARI, K.V, BALAKRISHNAN, KANSAL, M.; LATA, K.; KISHORE, V.V.N. State-of-the-art of anaerobic digestion technology for industrial wastewater treatment. Renewable and Sustainable Energy Reviews v. 4, p. 135 - 156, 2000.

RAMAKRISHNAN, A.; GUPTA, S.K. Anaerobic biogranulation in a hybrid reactor treating phenolic waste. Journal of Hazardous Materials, v. 137, p. 1488 - 1495, 2006.

REHFUSS, M; URBAN, J. Alcaligenes faecalis subsp. phenolicus subsp. nov. a phenoldegrading, denitrifying bacterium isolated from a graywater bioprocessor. Systematic and Applied Microbiology, v. 28, p. 421 - 429, 2005.

REINEKE, W. Aerobic and Anaerobic Biodegradation Potentials of Microorganisms. The Handbook of Environmental Chemistry, v 1, ed. B. Beek, Biodegradation and Persistence, 2001.

RIJN, J. V.; TAL, Y.; SCHREIER, H. J. Denitrification in recirculating systems: theory and applications. Aquacultural Engineering, v. 34, p. 364 - 376, 2006.

RIPLEY, L.E.; BOYLE, W.C.; CONVERSE, L.C. Improved alkalimetric monitoring for anaerobic digestion of high-strength wastes. Journal of Water Pollution Control Federation, v. 58, n. 5, 406 - 411, 1986.

RITTMANN, B. E; MCCARTY, P.L. Environmental Biotechnology: Principles and Aplications - Editora McGraw- Hill, 2001.

RODRIGUES, K. A. Uso de reatores biológicos com fungos para remoção de fenol de água residuária sintética. São Carlos, SP. Tese (Doutorado) - Escola de Engenharia de São Carlos, Universidade de São Paulo, 2006. 
ROJAS, M.L.B. Tratamento de fenol em reator anaeróbio horizontal de leito fixo (RAHLF) sob condições mesofílicas. Tese (Doutorado) - Escola de Engenharia de São Carlos, Universidade de São Paulo, 2001.

RUIZ, G.; JEISON, D.; CHAMY, R. Development of denitrifying and methanogenic activities in USB reactors for the treatment of wastewater: Effect of COD/N ratio. Process Biochemistry, v. 41, p. 1338 - 1342, 2006.

SADER, L. T. Avaliação de partículas poliméricas como material suporte em reator anaeróbio de leito fluidizado no tratamento de fenol. São Carlos. Tese (Mestrado) Departamento de Engenharia Química - UFSCar, 2005.

SANCINETTI, G. P. Degradação de fenol em reator anaeróbio de leito fluidizado. Tese (Doutorado). Universidade Federal de São Carlos, 2004.

SANTOS, S. G. Utilização de metanol, etanol e metano como doadores de elétrons para desnitrificação. Tese (doutourado) - São Carlos - SHS - EESC - USP, 2003.

SARFARAZ, S.; THOMAS, S.; TEWARI, U.K.; IYENGAR, L. Anoxic treatment of phenolic wasterwater in sequencing batch reactor. Water Research, v. 38, p. 965 - 971, 2004.

SEN, S.; DEMIRER, G.N. Anaerobic treatment of real textile wastewater with a fluidized bedreactor. Water Research, v. 37, p. 1868 - 1878, 2003.

SHIEH, W. K.; HSU, Y. Biomass Loss From an Anaerobic Fluidized bed Reactor Water Research, v. 30, n. 5, p. 1253 - 1257, 1996.

SHINODA, Y.; SAKAI Y.; UÉ, M.; HIRAISHI, A.; KATO, N. Isolation and characterization of a new denitrifying Spirillum capable of anaerobic degradation of phenol. Applied and Environmental Microbiology, v. 66, n. 4, p. 1286 - 1291, 2000.

TAVARES, C.R.G. Tratamento aeróbio de efluentes em bioreatores de leito fluidificado trifásico. Tese (Doutorado) - COPPE - UFRJ, 1992.

THOMAS, S.; SARFARAZ, S.; MISHRA, L.C.; IYENGAR L. Degradation of phenol and compounds by a defined denitrifying bacterial culture. World Journal Microbiology \& Biotechnology. v.18; p. $57-63,2002$. 
TSCHECH, A.; FUCHS, G. Anaerobic degradation of phenol by pure cultures of newly isolated denitrifying Pseudomonads. Arch Microbiol, v. 148, p. 213 - 217, 1987.

U.S. EPA - U.S. ENVIRONMENTAL PROTECTION AGENCY. Toxicological review of phenol, 2002. Disponível em: http://www.epa.gov/iriswebp/iris/toxreviews/0088-tr.pdf.

VAN SCHIE, P. M.; YOUNG, L. Y. Biodegradation of phenol: mechanisms and applications. Bioremediation Journal, v. 4, n. 1, p. 1 - 18, 2000.

VAN SCHIE, P. M.; YOUNG, L. Y. Isolation and characterization of phenol-degrading denitrifying bactéria. Applied and Environmental Microbiology, v. 64, n. 7, p. 2432 - 2438, 1998.

VEERESH, G. S., KUMAR, P.; MEHROTRA, I. Treatment of phenol and cresols in upflow anaerobic sludge blanket (UASB) process: a review. Water Research, v. 39, p. 154 - 170, 2005 .

YANGA, Y.; TSUKAHARA, K.; SAWAYAMA, S.; TAKAAKI, M. Anaerobic Digestion by a Fixed and Fluidized Hybrid Reactor Packed with Carbon Felt. Materials Science and Engineering. v. 24, p. 893 - 899, 2004.

ZHANG, T.; KE, S. Z.; LIU, Y.; FANG, H. P. Microbial characteristics of a methanogenic phenol-degrading sludge. Water Science \& Technology, v. 52, n. 1 - 2, p. 73 - 78, 2005.

ZHU, J.; LIN, J.; ZHANG, B.; YAN, X.; PENG, Z. Simultaneous removal of phenol and nitrate in an anaerobic bioreactor. Journal of Environmental Engineering, v. 132, n. 9, p. 1073 - 1077, 2006. 
APÊNDICE 
Tabela A1 - Valores das concentrações de fenol afluente e efluente do reator de leito fluidificado.

\begin{tabular}{|c|c|c|}
\hline \multirow{2}{*}{$\begin{array}{c}\text { dias de } \\
\text { operação }\end{array}$} & \multicolumn{2}{|c|}{ concentração de fenol (mg.L $\left.\mathrm{L}^{-1}\right)$} \\
\hline & afluente & efluente \\
\hline 2 & 57 & ND \\
\hline 3 & 55 & ND \\
\hline 4 & 48 & ND \\
\hline 5 & 48 & ND \\
\hline 6 & 49 & ND \\
\hline 7 & 49 & ND \\
\hline 8 & 45 & ND \\
\hline 9 & 49 & ND \\
\hline 10 & 54 & ND \\
\hline 11 & 108 & ND \\
\hline 12 & 103 & ND \\
\hline 13 & 119 & ND \\
\hline 15 & 114 & ND \\
\hline 16 & 97 & ND \\
\hline 17 & 104 & ND \\
\hline 18 & 95 & ND \\
\hline 19 & 106 & ND \\
\hline 22 & 112 & ND \\
\hline 24 & 111 & ND \\
\hline 26 & 112 & ND \\
\hline 29 & 100 & ND \\
\hline 31 & 110 & ND \\
\hline 33 & 105 & ND \\
\hline 36 & 105 & ND \\
\hline 38 & 134 & ND \\
\hline 40 & 145 & ND \\
\hline 43 & 233 & ND \\
\hline 45 & 231 & ND \\
\hline 47 & 234 & ND \\
\hline 50 & 193 & ND \\
\hline 52 & 170 & ND \\
\hline 54 & 226 & ND \\
\hline 57 & 215 & ND \\
\hline 59 & 221 & ND \\
\hline 61 & 227 & ND \\
\hline 64 & 183 & ND \\
\hline 66 & 296 & ND \\
\hline 68 & 258 & ND \\
\hline 71 & 313 & 9 \\
\hline 73 & 379 & ND \\
\hline 75 & 357 & ND \\
\hline
\end{tabular}


Tabela A1 - Valores das concentrações de fenol afluente e efluente do reator de leito fluidificado (continuação).

\begin{tabular}{|c|c|c|}
\hline 78 & 298 & ND \\
\hline 80 & 334 & ND \\
\hline 83 & 343 & ND \\
\hline 85 & 378 & 64 \\
\hline 87 & 345 & ND \\
\hline 89 & 339 & 5 \\
\hline 92 & 341 & ND \\
\hline 94 & 366 & ND \\
\hline 96 & 337 & ND \\
\hline 99 & 337 & ND \\
\hline 101 & 455 & 94 \\
\hline 102 & 462 & 183 \\
\hline 105 & 401 & 32 \\
\hline 107 & 418 & 72 \\
\hline 108 & 431 & 93 \\
\hline 109 & 412 & 103 \\
\hline 110 & 414 & 113 \\
\hline 111 & 468 & 110 \\
\hline 112 & 418 & 125 \\
\hline 113 & 405 & 120 \\
\hline 114 & 457 & 25 \\
\hline 115 & 390 & ND \\
\hline 117 & 417 & 79 \\
\hline 119 & 466 & 110 \\
\hline 120 & 418 & 102 \\
\hline 121 & 532 & 123 \\
\hline 125 & 506 & 113 \\
\hline 127 & 482 & 231 \\
\hline 128 & 507 & 194 \\
\hline 129 & 485 & 29 \\
\hline 131 & 478 & 229 \\
\hline 135 & 454 & 62 \\
\hline 137 & 502 & 131 \\
\hline 141 & 482 & 41 \\
\hline 143 & 485 & 110 \\
\hline 145 & 597 & 140 \\
\hline 148 & 563 & 226 \\
\hline 150 & 529 & 210 \\
\hline 155 & 587 & 208 \\
\hline 157 & 526 & 236 \\
\hline 162 & 576 & 338 \\
\hline
\end{tabular}


Tabela A2 - Valores da vazão efluente medidos durante a operação contínua reator anaeróbio de leito fluidificado.

\begin{tabular}{|c|c|}
\hline $\begin{array}{c}\text { dias de } \\
\text { operação }\end{array}$ & $\begin{array}{l}\text { Vazão média } \\
\text { efluente- }\left(\mathrm{mL} \cdot \mathrm{h}^{-1}\right)\end{array}$ \\
\hline 1 & 173 \\
\hline 3 & 180 \\
\hline 5 & 151 \\
\hline 6 & 168 \\
\hline 7 & 143 \\
\hline 8 & 142 \\
\hline 9 & 217 \\
\hline 10 & 182 \\
\hline 11 & 206 \\
\hline 12 & 187 \\
\hline 13 & 208 \\
\hline 15 & 254 \\
\hline 16 & 257 \\
\hline 17 & 170 \\
\hline 18 & 166 \\
\hline 19 & 179 \\
\hline 20 & 185 \\
\hline 21 & 193 \\
\hline 22 & 202 \\
\hline 23 & 186 \\
\hline 25 & 168 \\
\hline 26 & 175 \\
\hline 27 & 163 \\
\hline 28 & 153 \\
\hline 29 & 174 \\
\hline 30 & 163 \\
\hline 31 & 179 \\
\hline 33 & 183 \\
\hline 34 & 178 \\
\hline 35 & 176 \\
\hline 36 & 190 \\
\hline 37 & 189 \\
\hline 38 & 190 \\
\hline 39 & 194 \\
\hline 40 & 178 \\
\hline 41 & 178 \\
\hline 42 & 180 \\
\hline 43 & 189 \\
\hline 44 & 176 \\
\hline 45 & 179 \\
\hline 46 & 180 \\
\hline 47 & 183 \\
\hline 48 & 183 \\
\hline
\end{tabular}

Continua 
Tabela A2 - Valores da vazão efluente medidos durante a operação contínua reator anaeróbio de leito fluidificado (continuação).

\begin{tabular}{|c|c|}
\hline 49 & 181 \\
\hline 50 & 164 \\
\hline 51 & 189 \\
\hline 52 & 184 \\
\hline 53 & 187 \\
\hline 54 & 192 \\
\hline 55 & 153 \\
\hline 57 & 186 \\
\hline 58 & 169 \\
\hline 59 & 181 \\
\hline 60 & 184 \\
\hline 61 & 160 \\
\hline 62 & 190 \\
\hline 63 & 163 \\
\hline 64 & 190 \\
\hline 65 & 203 \\
\hline 66 & 200 \\
\hline 68 & 191 \\
\hline 69 & 159 \\
\hline 70 & 210 \\
\hline 71 & 213 \\
\hline 72 & 214 \\
\hline 73 & 182 \\
\hline 74 & 206 \\
\hline 74 & 201 \\
\hline 75 & 185 \\
\hline 77 & 162 \\
\hline 78 & 165 \\
\hline 79 & 172 \\
\hline 80 & 166 \\
\hline 81 & 170 \\
\hline 82 & 170 \\
\hline 83 & 170 \\
\hline 84 & 195 \\
\hline 85 & 188 \\
\hline 86 & 170 \\
\hline 87 & 176 \\
\hline 88 & 171 \\
\hline 89 & 176 \\
\hline 90 & 180 \\
\hline 90 & 180 \\
\hline 91 & 168 \\
\hline 92 & 179 \\
\hline 93 & 171 \\
\hline 94 & 155 \\
\hline 95 & 165 \\
\hline
\end{tabular}


Tabela A-2 Valores das vazões efluente medida durante a operação contínua reator anaeróbio de leito fluidificado (continuação).

\begin{tabular}{cc}
96 & 171 \\
97 & 165 \\
98 & 167 \\
100 & 185 \\
101 & 172 \\
102 & 156 \\
104 & 184 \\
105 & 168 \\
106 & 173 \\
107 & 165 \\
108 & 171 \\
109 & 173 \\
110 & 169 \\
111 & 166 \\
112 & 154 \\
113 & 167 \\
114 & 178 \\
115 & 187 \\
116 & 191 \\
117 & 211 \\
119 & 185 \\
120 & 182 \\
121 & 169 \\
122 & 180 \\
124 & 159 \\
125 & 177 \\
127 & 170 \\
128 & 182 \\
130 & 176 \\
131 & 186 \\
134 & 190 \\
135 & 158 \\
136 & 178 \\
137 & 170 \\
139 & 175 \\
143 & 163 \\
145 & 178 \\
148 & 190 \\
150 & 160 \\
155 & 175 \\
157 & 186 \\
160 & 184 \\
162 & 186 \\
\hline &
\end{tabular}


Tabela A3 - Valores das concentrações de DQO afluente e efluente medidas durante a operação contínua reator anaeróbio de leito fluidificado.

\begin{tabular}{|c|c|c|}
\hline \multirow{2}{*}{$\begin{array}{c}\text { dias de } \\
\text { operação }\end{array}$} & \multicolumn{2}{|c|}{ DQO $\left(\mathrm{mg} \cdot \mathrm{L}^{-1}\right)$} \\
\hline & afluente & efluente \\
\hline 2 & 758 & 225 \\
\hline 3 & 648 & 130 \\
\hline 4 & 702 & 134 \\
\hline 5 & 624 & 101 \\
\hline 6 & 806 & 86 \\
\hline 7 & 752 & 100 \\
\hline 8 & 761 & 103 \\
\hline 9 & 668 & 93 \\
\hline 11 & 694 & 109 \\
\hline 12 & 900 & 104 \\
\hline 16 & 779 & 88 \\
\hline 17 & 973 & 82 \\
\hline 19 & 819 & 64 \\
\hline 22 & 1050 & 72 \\
\hline 24 & 1026 & 121 \\
\hline 26 & 1062 & 64 \\
\hline 29 & 799 & 30 \\
\hline 31 & 1026 & 96 \\
\hline 33 & 1050 & 93 \\
\hline 36 & 929 & 64 \\
\hline 38 & 941 & 152 \\
\hline 40 & 1018 & 99 \\
\hline 43 & 1394 & 107 \\
\hline 45 & 1358 & 107 \\
\hline 47 & 1366 & 131 \\
\hline 50 & 1066 & 123 \\
\hline 52 & 1005 & 216 \\
\hline 54 & 1426 & 99 \\
\hline 57 & 1058 & 164 \\
\hline 59 & 1321 & 148 \\
\hline 61 & 1260 & 168 \\
\hline 64 & 1147 & 156 \\
\hline 66 & 1491 & 107 \\
\hline 68 & 1297 & 87 \\
\hline 71 & 1426 & 204 \\
\hline 73 & 1823 & 180 \\
\hline 75 & 1746 & 119 \\
\hline 78 & 1394 & 164 \\
\hline 80 & 1499 & 168 \\
\hline 83 & 1613 & 164 \\
\hline 85 & 1568 & 358 \\
\hline 87 & 1576 & 423 \\
\hline
\end{tabular}


Tabela A3 - Valores das concentrações de DQO afluente e efluente medidas durante a operação contínua reator anaeróbio de leito fluidificado (continuação).

\begin{tabular}{ccc}
89 & 1528 & 172 \\
92 & 1192 & 119 \\
94 & 1540 & 115 \\
96 & 1406 & 119 \\
99 & 1436 & 133 \\
101 & 2027 & 530 \\
107 & 1833 & 514 \\
108 & 2165 & 586 \\
110 & 2246 & 756 \\
113 & 1488 & 448 \\
115 & 1766 & 234 \\
117 & 1737 & 459 \\
120 & 1725 & 494 \\
123 & 1350 & 160 \\
125 & 1581 & 387 \\
127 & 1397 & 566 \\
129 & 1605 & 443 \\
131 & 1373 & 453 \\
135 & 1387 & 491 \\
137 & 1581 & 623 \\
141 & 1515 & 222 \\
143 & 1463 & 344 \\
145 & 1737 & 387 \\
148 & 1652 & 604 \\
150 & 1482 & 561 \\
155 & 1708 & 618 \\
157 & 1515 & 746 \\
162 & 1586 & 812 \\
\hline
\end{tabular}


Tabela A4 - Valores das concentrações de $\mathrm{N}-\mathrm{NO}_{3}$ afluente e efluente medidas durante a operação contínua reator anaeróbio de leito fluidificado.

\begin{tabular}{|c|c|c|}
\hline \multirow{2}{*}{$\begin{array}{c}\text { dias de } \\
\text { operação }\end{array}$} & \multicolumn{2}{|c|}{$\mathrm{N}-\mathrm{NO}_{3}\left(\mathrm{mg} \cdot \mathrm{L}^{-1}\right)$} \\
\hline & afluente & efluente \\
\hline 3 & 44 & 5 \\
\hline 4 & 49 & 7 \\
\hline 5 & 43 & 5 \\
\hline 6 & 43 & 0 \\
\hline 7 & 46 & 0 \\
\hline 8 & 46 & 0 \\
\hline 9 & 42 & 0 \\
\hline 10 & 43 & 0 \\
\hline 11 & 45 & 0 \\
\hline 12 & 80 & 8 \\
\hline 13 & 80 & 8 \\
\hline 15 & 81 & 8 \\
\hline 16 & 86 & 9 \\
\hline 18 & 86 & 14 \\
\hline 19 & 64 & 10 \\
\hline 22 & 78 & 4 \\
\hline 24 & 79 & 5 \\
\hline 26 & 79 & 6 \\
\hline 29 & 77 & 7 \\
\hline 31 & 78 & 6 \\
\hline 33 & 82 & 24 \\
\hline 36 & 76 & 1 \\
\hline 38 & 95 & 6 \\
\hline 40 & 101 & 4 \\
\hline 43 & 178 & 19 \\
\hline 45 & 174 & 11 \\
\hline 47 & 168 & 13 \\
\hline 50 & 149 & 16 \\
\hline 52 & 136 & 18 \\
\hline 54 & 154 & 33 \\
\hline 57 & 148 & 31 \\
\hline 59 & 157 & 32 \\
\hline 61 & 154 & 24 \\
\hline 64 & 149 & 23 \\
\hline 66 & 216 & 23 \\
\hline 68 & 187 & 19 \\
\hline 71 & 237 & 8 \\
\hline 73 & 307 & 24 \\
\hline 75 & 272 & 42 \\
\hline 78 & 197 & 1 \\
\hline 80 & 256 & 21 \\
\hline 83 & 288 & 81 \\
\hline
\end{tabular}


Tabela A4 - Valores das concentrações de $\mathrm{N}-\mathrm{NO}_{3}$ afluente e efluente medidas durante a operação contínua reator anaeróbio de leito fluidificado (continuação).

\begin{tabular}{ccc}
85 & 280 & 136 \\
87 & 205 & 33 \\
89 & 285 & 75 \\
92 & 260 & 86 \\
94 & 267 & 75 \\
96 & 254 & 64 \\
99 & 270 & 75 \\
101 & 305 & 111 \\
102 & 347 & 146 \\
105 & 298 & 85 \\
107 & 335 & 107 \\
108 & 339 & 138 \\
109 & 344 & 149 \\
110 & 346 & 163 \\
113 & 286 & 131 \\
114 & 328 & 70 \\
115 & 299 & 82 \\
117 & 288 & 107 \\
120 & 364 & 162 \\
121 & 352 & 129 \\
125 & 368 & 162 \\
127 & 284 & 199 \\
128 & 354 & 194 \\
129 & 351 & 159 \\
131 & 351 & 201 \\
135 & 340 & 194 \\
137 & 374 & 210 \\
141 & 373 & 158 \\
143 & 412 & 175 \\
145 & 382 & 162 \\
148 & 361 & 148 \\
150 & 328 & 154 \\
155 & 396 & 174 \\
157 & 362 & 200 \\
162 & 399 & 208 \\
\hline & & \\
139 &
\end{tabular}


Tabela A5 - Valores da concentração de $\mathrm{N}-\mathrm{NO}_{2}$ efluente medidas durante a operação contínua reator anaeróbio de leito fluidificado (continuação).

\begin{tabular}{|c|c|}
\hline $\begin{array}{c}\text { dias de } \\
\text { operação }\end{array}$ & $\begin{array}{c}\mathrm{N}-\mathrm{NO}_{2}\left(\mathrm{mg} \cdot \mathrm{L}^{-1}\right) \\
\text { efluente }\end{array}$ \\
\hline 2 & 0,3 \\
\hline 3 & 1,7 \\
\hline 4 & 1,1 \\
\hline 5 & 0,9 \\
\hline 9 & 0,0 \\
\hline 12 & 0,1 \\
\hline 16 & 1,7 \\
\hline 19 & 3,8 \\
\hline 24 & 2,3 \\
\hline 26 & 3,0 \\
\hline 29 & 3,5 \\
\hline 31 & 2,7 \\
\hline 33 & 5,0 \\
\hline 35 & 1,0 \\
\hline 37 & 1,1 \\
\hline 39 & 0,9 \\
\hline 43 & 1,0 \\
\hline 45 & 1,0 \\
\hline 47 & 1,4 \\
\hline 50 & 1,7 \\
\hline 52 & 1,6 \\
\hline 54 & 2,2 \\
\hline 57 & 2,8 \\
\hline 59 & 3,0 \\
\hline 61 & 3,0 \\
\hline 64 & 2,1 \\
\hline 66 & 1,2 \\
\hline 68 & 1,3 \\
\hline 71 & 0,2 \\
\hline 73 & 0,8 \\
\hline 75 & 0,5 \\
\hline 78 & 1,3 \\
\hline 80 & 0,3 \\
\hline 83 & 0,1 \\
\hline 85 & 0,3 \\
\hline 87 & 0,1 \\
\hline 89 & 0,5 \\
\hline 92 & 0,3 \\
\hline 94 & 0,7 \\
\hline 96 & 0,4 \\
\hline 100 & 0,4 \\
\hline 101 & 0,5 \\
\hline 107 & 0,4 \\
\hline 108 & 0,4 \\
\hline
\end{tabular}

Continua 
Tabela A5 - Valores da concentração de $\mathrm{N}-\mathrm{NO}_{2}$ efluente medidas durante a operação contínua reator anaeróbio de leito fluidificado (continuação).

\begin{tabular}{lc}
110 & 0,2 \\
113 & 0,9 \\
115 & 0,3 \\
117 & 0,1 \\
120 & 0,4 \\
122 & 0,7 \\
124 & 0,2 \\
127 & 0,2 \\
129 & 0,4 \\
131 & 0,2 \\
135 & 0,2 \\
137 & 0,1 \\
141 & 0,9 \\
143 & 0,8 \\
145 & 2,5 \\
148 & 0,8 \\
150 & 1,6 \\
155 & 10,1 \\
157 & 8,9 \\
159 & 8,9 \\
162 & 1,4 \\
\hline
\end{tabular}


Tabela A6 - Valores do pH afluente e efluente medidos durante a operação contínua reator anaeróbio de leito fluidificado.

\begin{tabular}{|c|c|c|}
\hline \multirow{2}{*}{$\begin{array}{c}\text { dias de } \\
\text { operação }\end{array}$} & \multicolumn{2}{|c|}{$\mathrm{pH}$} \\
\hline & afluente & efluente \\
\hline 2 & 6,1 & 8,1 \\
\hline 3 & 6,1 & 8,0 \\
\hline 4 & 6,5 & 8,0 \\
\hline 5 & 6,1 & 8,1 \\
\hline 6 & 6,1 & 7,8 \\
\hline 7 & 6,0 & 7,8 \\
\hline 8 & 6,2 & 7,9 \\
\hline 9 & 6,1 & 7,8 \\
\hline 10 & 6,0 & 7,7 \\
\hline 11 & 5,9 & 8,0 \\
\hline 12 & 6,2 & 7,9 \\
\hline 13 & 6,5 & 7,9 \\
\hline 14 & 6,2 & 7,9 \\
\hline 15 & 6,2 & 8,0 \\
\hline 16 & 6,0 & 7,8 \\
\hline 17 & 5,9 & 7,9 \\
\hline 18 & 6,2 & 8,2 \\
\hline 19 & 6,3 & 7,7 \\
\hline 20 & 6,5 & 7,9 \\
\hline 21 & 6,4 & 7,9 \\
\hline 22 & 6,5 & 7,9 \\
\hline 23 & 6,3 & 8,4 \\
\hline 24 & 6,4 & 7,9 \\
\hline 25 & 6,2 & 8,1 \\
\hline 27 & 6,2 & 8,0 \\
\hline 28 & 6,2 & 7,6 \\
\hline 29 & 6,3 & 7,7 \\
\hline 30 & 6,2 & 7,9 \\
\hline 31 & 6,2 & 7,7 \\
\hline 33 & 6,2 & 7,7 \\
\hline 34 & 6,1 & 7,8 \\
\hline 35 & 6,3 & 7,9 \\
\hline 36 & 6,2 & 7,7 \\
\hline 37 & 6,3 & 7,8 \\
\hline 38 & 6,2 & 8,0 \\
\hline 39 & 6,2 & 8,0 \\
\hline 40 & 6,3 & 8,0 \\
\hline 41 & 6,1 & 7,7 \\
\hline 42 & 6,3 & 8,0 \\
\hline 43 & 6,4 & 8,0 \\
\hline 44 & 6,1 & 7,8 \\
\hline 45 & 6,3 & 8,1 \\
\hline 46 & 6,4 & 8,0 \\
\hline
\end{tabular}

Continua 
Tabela A6 - Valores do pH afluente e efluente medidos durante a operação contínua reator anaeróbio de leito fluidificado (continuação).

$\begin{array}{lll}47 & 6,2 & 8,0 \\ 48 & 6,2 & 8,0 \\ 49 & 6,2 & 8,0 \\ 50 & 6,1 & 8,0 \\ 51 & 6,3 & 7,9 \\ 52 & 6,1 & 7,9 \\ 53 & 6,1 & 7,9 \\ 54 & 6,3 & 8,1 \\ 55 & 6,1 & 8,0 \\ 56 & 6,0 & 7,8 \\ 57 & 6,2 & 7,9 \\ 58 & 6,1 & 7,8 \\ 59 & 6,1 & 7,8 \\ 60 & 6,0 & 8,2 \\ 61 & 6,2 & 8,0 \\ 62 & 6,5 & 7,9 \\ 63 & 6,3 & 7,9 \\ 64 & 6,1 & 8,0 \\ 65 & 6,2 & 8,1 \\ 66 & 5,9 & 8,0 \\ 67 & 6,3 & 8,0 \\ 68 & 6,0 & 8,1 \\ 69 & 5,9 & 7,9 \\ 70 & 6,1 & 8,1 \\ 71 & 5,9 & 7,9 \\ 72 & 6,3 & 7,7 \\ 73 & 5,9 & 7,9 \\ 74 & 6,3 & 7,9 \\ 75 & 6,1 & 8,0 \\ 76 & 6,0 & 8,1 \\ 77 & 5,7 & 7,8 \\ 78 & 6,3 & 8,2 \\ 79 & 6,2 & 8,3 \\ 80 & 6,5 & 8,2 \\ 81 & 5,9 & 8,0 \\ 82 & 6,4 & 8,0 \\ 83 & 6,0 & 8,0 \\ 85 & 6,2 & 7,8 \\ 86 & 6,3 & 8,3 \\ 87 & 6,2 & 8,3 \\ 88 & 6,7 & 8,0 \\ 89 & 6,1 & 7,9 \\ 90 & 6,1 & 7,9 \\ 91 & 6,1 & 7,9 \\ 92 & 6,7 & 7,9 \\ 93 & 6,0 & 7,9 \\ & & \end{array}$


Tabela A6 - Valores do pH afluente e efluente medidos durante a operação contínua reator anaeróbio de leito fluidificado (continuação).

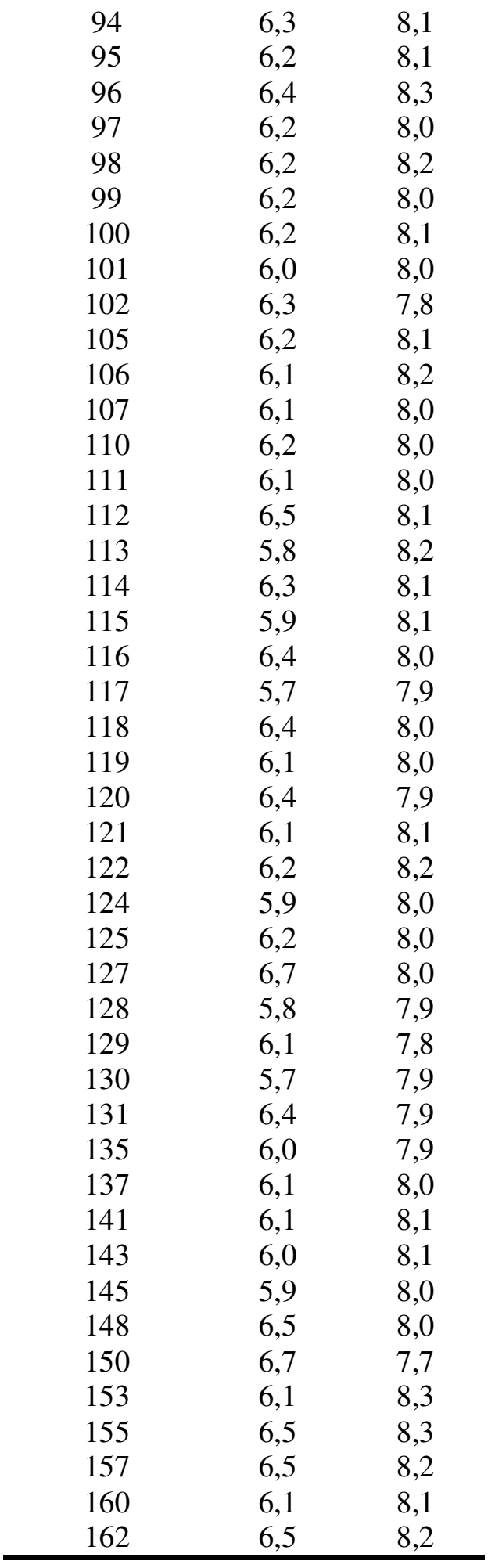


Tabela A7 - Valores das concentrações de alcalinidade a bicarbonato afluente e efluente medidos durante a operação contínua reator anaeróbio de leito fluidificado.

\begin{tabular}{ccc}
\hline \multirow{2}{*}{ dias de } & \multicolumn{2}{c}{ Alcalinidade a } \\
operação & bicarbonato $\left(\mathrm{mg} . \mathrm{L}^{-1}\right)$ \\
\cline { 2 - 3 } & afluente & efluente \\
\hline 2 & 0,0 & 988,9 \\
3 & 24,2 & 819,1 \\
4 & 0,0 & 608,9 \\
5 & 9,7 & 475,5 \\
7 & 23,4 & 363,9 \\
8 & 0,0 & 325,3 \\
9 & 0,0 & 298,4 \\
11 & 5,8 & 289,9 \\
12 & 26,6 & 319,2 \\
13 & 11,9 & 347,1 \\
16 & 9,2 & 345,2 \\
17 & 0,0 & 335,8 \\
19 & 0,0 & 305,3 \\
21 & 0,0 & 309,2 \\
22 & 0,0 & 318,9 \\
26 & 0,0 & 313,7 \\
29 & 2,0 & 307,0 \\
31 & 0,0 & 301,3 \\
33 & 4,5 & 247,4 \\
36 & 17,1 & 318,9 \\
38 & 0,0 & 363,2 \\
40 & 17,8 & 416,3 \\
43 & 0,0 & 486,8 \\
45 & 0,0 & 533,2 \\
47 & 0,6 & 528,2 \\
50 & 9,2 & 480,9 \\
52 & 17,1 & 507,2 \\
54 & 17,6 & 494,5 \\
57 & 0,0 & 441,8 \\
59 & 0,0 & 447,1 \\
61 & 2,4 & 480,9 \\
64 & 9,7 & 491,0 \\
66 & 0,2 & 594,2 \\
68 & 5,8 & 713,2 \\
71 & 2,8 & 715,8 \\
73 & 0,0 & 853,2 \\
75 & 1,7 & 732,4 \\
78 & 18,5 & 809,0 \\
80 & 60,7 & 870,7 \\
83 & 4,2 & 759,8 \\
85 & 13,8 & 600,9 \\
87 & 15,4 & 716,0 \\
89 & 6,7 & 657,0 \\
& & \\
& &
\end{tabular}

Continua 
Tabela A7 - Valores das concentrações de alcalinidade a bicarbonato afluente e efluente medidos durante a operação contínua reator anaeróbio de leito fluidificado (continuação).

\begin{tabular}{ccc}
92 & 93,0 & 721,1 \\
94 & 24,9 & 731,4 \\
96 & 52,7 & 795,4 \\
100 & 9,1 & 848,0 \\
101 & 6,1 & 818,5 \\
106 & 11,6 & 937,2 \\
108 & 94,4 & 880,1 \\
110 & 9,3 & 779,2 \\
113 & 0,0 & 878,4 \\
115 & 5,5 & 903,7 \\
117 & 0,0 & 822,9 \\
120 & 23,3 & 744,8 \\
123 & 0,0 & 860,3 \\
125 & 24,5 & 686,7 \\
127 & 91,7 & 635,6 \\
129 & 18,6 & 757,6 \\
131 & 120,6 & 608,9 \\
135 & 12,3 & 692,3 \\
137 & 3,3 & 614,4 \\
141 & 11,9 & 862,0 \\
143 & 0,0 & 829,6 \\
145 & 24,2 & 912,0 \\
148 & 105,5 & 1025,9 \\
150 & 85,6 & 1012,9 \\
155 & 62,6 & 1062,3 \\
157 & 56,3 & 859,3 \\
162 & 53,3 & 956,7 \\
\hline
\end{tabular}


Tabela A8 - Valores das concentrações de ácidos voláteis totais afluente e efluente medidos durante a operação contínua reator anaeróbio de leito fluidificado

\begin{tabular}{|c|c|c|}
\hline \multirow{2}{*}{$\begin{array}{c}\text { dias de } \\
\text { operação }\end{array}$} & \multicolumn{2}{|c|}{$\begin{array}{l}\text { Ácidos Voláteis } \\
\text { Totais }\left(\mathrm{mg}^{-L^{-1}}\right)\end{array}$} \\
\hline & afluente & efluente \\
\hline 2 & 68,4 & 85,5 \\
\hline 3 & 91,2 & 74,1 \\
\hline 4 & 68,4 & 57,0 \\
\hline 5 & 74,1 & 57,0 \\
\hline 7 & 79,8 & 51,3 \\
\hline 8 & 57,0 & 40,5 \\
\hline 9 & 46,2 & 30,8 \\
\hline 11 & 57,0 & 36,5 \\
\hline 12 & 74,1 & 35,3 \\
\hline 13 & 55,8 & 28,5 \\
\hline 16 & 79,2 & 26,8 \\
\hline 17 & 46,5 & 23,8 \\
\hline 19 & 45,9 & 23,2 \\
\hline 21 & 45,3 & 21,4 \\
\hline 22 & 47,7 & 21,4 \\
\hline 26 & 52,4 & 22,6 \\
\hline 29 & 48,3 & 23,2 \\
\hline 31 & 52,4 & 23,8 \\
\hline 33 & 45,9 & 42,3 \\
\hline 36 & 66,7 & 26,2 \\
\hline 38 & 67,3 & 21,1 \\
\hline 40 & 63,2 & 23,4 \\
\hline 43 & 45,7 & 22,8 \\
\hline 45 & 49,2 & 21,7 \\
\hline 47 & 46,8 & 28,7 \\
\hline 50 & 65,0 & 21,1 \\
\hline 52 & 72,6 & 19,3 \\
\hline 54 & 64,4 & 24,6 \\
\hline 57 & 48,0 & 23,4 \\
\hline 59 & 44,5 & 22,2 \\
\hline 61 & 42,7 & 21,1 \\
\hline 64 & 64,4 & 22,2 \\
\hline 66 & 55,7 & 61,5 \\
\hline 68 & 63,2 & 22,6 \\
\hline 71 & 70,2 & 23,2 \\
\hline 73 & 57,4 & 25,5 \\
\hline 75 & 52,2 & 24,9 \\
\hline 78 & 112,5 & 29,0 \\
\hline 80 & 109,0 & 42,9 \\
\hline 83 & 79,4 & 28,4 \\
\hline 85 & 84,1 & 25,5 \\
\hline 87 & 77,7 & 24,4 \\
\hline 89 & 76,0 & 29,0 \\
\hline
\end{tabular}


Tabela A8 - Valores das concentrações de ácidos voláteis totais afluente e efluente medidos durante a operação contínua reator anaeróbio de leito fluidificado (continuação).

\begin{tabular}{ccc}
92 & 98,6 & 25,5 \\
94 & 109,0 & 34,8 \\
96 & 111,9 & 24,4 \\
100 & 99,1 & 27,3 \\
101 & 85,2 & 22,6 \\
106 & 95,7 & 22,0 \\
108 & 128,7 & 22,6 \\
110 & 147,8 & 29,0 \\
113 & 95,1 & 37,7 \\
115 & 84,6 & 27,3 \\
117 & 62,6 & 29,0 \\
120 & 144,9 & 31,3 \\
123 & 61,5 & 29,6 \\
125 & 126,4 & 24,9 \\
127 & 133,9 & 25,5 \\
129 & 133,4 & 27,3 \\
135 & 107,3 & 25,5 \\
137 & 107,3 & 23,2 \\
141 & 107,8 & 34,2 \\
143 & 99,7 & 40,6 \\
145 & 83,5 & 29,6 \\
148 & 116,0 & 34,2 \\
150 & 153,6 & 23,2 \\
155 & 162,3 & 38,8 \\
157 & 133,4 & 43,5 \\
162 & 167,0 & 151,3 \\
\hline & & \\
\end{tabular}


Tabela A9 - Valores das taxas de carregamento de fenol aplicada afluente medidos durante a operação contínua reator anaeróbio de leito fluidificado.

\begin{tabular}{|c|c|}
\hline $\begin{array}{l}\text { dias de } \\
\text { operação }\end{array}$ & 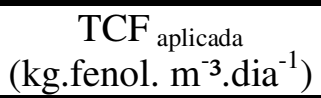 \\
\hline 1 & 0,07 \\
\hline 3 & 0,08 \\
\hline 5 & 0,06 \\
\hline 6 & 0,07 \\
\hline 7 & 0,06 \\
\hline 8 & 0,05 \\
\hline 9 & 0,08 \\
\hline 10 & 0,08 \\
\hline 11 & 0,18 \\
\hline 12 & 0,15 \\
\hline 13 & 0,20 \\
\hline 16 & 0,20 \\
\hline 17 & 0,14 \\
\hline 18 & 0,13 \\
\hline 19 & 0,15 \\
\hline 22 & 0,20 \\
\hline 26 & 0,16 \\
\hline 29 & 0,14 \\
\hline 31 & 0,16 \\
\hline 33 & 0,16 \\
\hline 36 & 0,16 \\
\hline 38 & 0,21 \\
\hline 40 & 0,21 \\
\hline 43 & 0,36 \\
\hline 45 & 0,34 \\
\hline 47 & 0,35 \\
\hline 50 & 0,26 \\
\hline 52 & 0,26 \\
\hline 54 & 0,36 \\
\hline 57 & 0,33 \\
\hline 59 & 0,33 \\
\hline 61 & 0,30 \\
\hline 64 & 0,29 \\
\hline 66 & 0,49 \\
\hline 68 & 0,41 \\
\hline 71 & 0,55 \\
\hline 73 & 0,57 \\
\hline 75 & 0,54 \\
\hline 78 & 0,41 \\
\hline 80 & 0,46 \\
\hline 83 & 0,48 \\
\hline 85 & 0,59 \\
\hline 87 & 0,50 \\
\hline 89 & 0,57 \\
\hline
\end{tabular}

Continua 
Tabela A9 - Valores das taxas de carregamento de fenol aplicada afluente medidos durante a operação contínua reator anaeróbio de leito fluidificado (continuação).

\begin{tabular}{cc}
92 & 0,58 \\
94 & 0,54 \\
96 & 0,55 \\
101 & 0,75 \\
102 & 0,69 \\
105 & 0,64 \\
107 & 0,66 \\
108 & 0,70 \\
109 & 0,68 \\
110 & 0,67 \\
111 & 0,68 \\
112 & 0,58 \\
113 & 0,61 \\
114 & 0,65 \\
115 & 0,59 \\
117 & 0,72 \\
119 & 0,71 \\
120 & 0,64 \\
121 & 0,82 \\
125 & 0,81 \\
127 & 0,72 \\
128 & 0,82 \\
131 & 0,79 \\
135 & 0,58 \\
137 & 0,66 \\
143 & 0,59 \\
145 & 0,77 \\
148 & 0,81 \\
150 & 0,63 \\
155 & 0,77 \\
157 & 0,73 \\
162 & 0,80 \\
\hline &
\end{tabular}


Tabela A10 - Valores efluentes das concentrações de Sólidos Suspensos, Totais, Voláteis e Fixos medidos durante a operação contínua reator anaeróbio de leito fluidificado.

\begin{tabular}{|c|c|c|c|}
\hline $\begin{array}{c}\text { dias de } \\
\text { operação }\end{array}$ & $\begin{array}{c}\text { SST } \\
\left(\mathrm{mg} . \mathrm{L}^{-1}\right)\end{array}$ & $\begin{array}{c}\mathrm{SSV} \\
\left(\mathrm{mg} \cdot \mathrm{L}^{-1}\right)\end{array}$ & $\begin{array}{c}\mathrm{SSF} \\
\left(\mathrm{mg} \cdot \mathrm{L}^{-1}\right)\end{array}$ \\
\hline 3 & 158 & 158 & 0 \\
\hline 5 & 156 & 154 & 2 \\
\hline 9 & 50 & 46 & 4 \\
\hline 11 & 100 & 68 & 32 \\
\hline 16 & 40 & 30 & 10 \\
\hline 19 & 82 & 62 & 20 \\
\hline 22 & 54 & 54 & 0 \\
\hline 24 & 54 & 54 & 0 \\
\hline 26 & 76 & 50 & 26 \\
\hline 29 & 84 & 64 & 20 \\
\hline 36 & 80 & 66 & 14 \\
\hline 40 & 74 & 56 & 18 \\
\hline 43 & 104 & 86 & 18 \\
\hline 47 & 84 & 84 & 0 \\
\hline 52 & 76 & 72 & 4 \\
\hline 57 & 62 & 38 & 24 \\
\hline 59 & 100 & 70 & 30 \\
\hline 68 & 82 & 52 & 30 \\
\hline 71 & 96 & 60 & 36 \\
\hline 73 & 146 & 134 & 12 \\
\hline 75 & 70 & 62 & 8 \\
\hline 78 & 122 & 104 & 18 \\
\hline 82 & 77 & 77 & 0 \\
\hline 83 & 70 & 60 & 10 \\
\hline 85 & 86 & 74 & 12 \\
\hline 89 & 127 & 106 & 21 \\
\hline 92 & 100 & 93 & 7 \\
\hline 101 & 114 & 114 & 0 \\
\hline 110 & 122 & 120 & 2 \\
\hline 113 & 136 & 108 & 28 \\
\hline 118 & 58 & 58 & 0 \\
\hline 120 & 216 & 142 & 74 \\
\hline 131 & 86 & 78 & 8 \\
\hline 135 & 154 & 138 & 16 \\
\hline 137 & 152 & 108 & 44 \\
\hline 141 & 200 & 192 & 8 \\
\hline 143 & 152 & 48 & 104 \\
\hline 145 & 96 & 96 & 0 \\
\hline 148 & 216 & 208 & 8 \\
\hline 150 & 78 & 78 & 0 \\
\hline 155 & 82 & 82 & 0 \\
\hline 157 & 102 & 98 & 4 \\
\hline 162 & 70 & 56 & 14 \\
\hline
\end{tabular}

